INSTITUTO DE PESQUISAS ENERGÉTICAS E NUCLEARES

Autarquia associada à Universidade de São Paulo

\title{
FUNCIONALIZAÇÃO DA SUPERFÍCIE DE NANOPARTÍCULAS SUPERPARAMAGNÉTICAS ENCAPSULADAS POR QUITOSANA PARA A IMOBILIZAÇÃO DE PROTEÍNAS
}

José Silva de Sousa

Dissertação apresentada como parte dos requisitos para a obtenção do Grau de Mestre em Ciências na Área de Tecnologia Nuclear Materiais

Orientadora:

Profa. Dra.Mitiko Yamaura

São Paulo 2010 


\section{DEDICATÓRIA}

\section{Dedico esse trabalho}

Aos meus pais que com muito esforço e luta me proporcionaram uma infância saudável e uma boa base acadêmica, primordiais para a formação do meu caráter. Agradeço a vocês por serem meu exemplo de vida.

À minha esposa pelo apoio e incentivo, que me ajudaram a vencer os momentos mais difíceis, sendo de vital importância para a concretização deste trabalho.

Aos meus amigos inseparáveis Bill e Vesgo, que com toda sua humildade, simplicidade e amor incondicional me alegraram todos os dias da minha vida.

Não poderia deixar de agradecer a Deus por todas as experiências que ele me ofertou nesses anos, as quais permitiram que eu crescesse espiritualmente, emocionalmente e profissionalmente.

Ao vencer mais essa etapa ao longo desses anos, aprendi que não há barreira intransponível na vida quando se luta com honestidade, muita dedicação e perseverança, e que Deus está sempre presente em todos os instantes, sejam eles bons ou ruins, renovando as energias e dando forças para seguir em frente sem fraquejar.

Muito obrigado por tudo 


\section{AGRADECIMENTOS}

Ao Instituto de Pesquisas Energéticas e Nucleares, IPEN-CNEN/SP, por me fornecer todas as condições a conclusão deste trabalho.

À Prof ${ }^{a}$. Dr a . Mitiko Yamaura, uma orientadora dedicada, incansável, de uma capacidade incontestável e admirável. Sou muito grato por tudo que fez por mim nesses anos em que estive sob sua orientação, com certeza fui muito feliz na escolha que fiz.

Ao Prof. Dr. Ademar Benévolo Lugão e à Prof ${ }^{a}$. Dr ${ }^{a}$. Maria Aparecida Faustino Pires pela oportunidade de concluir mais essa etapa na minha vida.

Ao Prof. Dr. Luis Filipe Carvalho Pedroso de Lima que me incentivou e estimulou a completar meus estudos, desde a graduação até conclusão do mestrado.

À Profa . Dr a . Maria Aparecida Pires Camillo, "Cidinha", e ao Ao Prof. Dr. Álvaro Antonio Alencar de Queiroz, que me auxiliaram nos ensaios biológicos.

À Profa . Dr a . Claudia Giovedi, "Claudinha", do CTMSP, uma amiga e uma profissional acima da média.

Ao amigo Sérgio Antônio Romero do Instituto de Física pelos ensaios magnéticos.

Aos amigos Eleosmar Gasparin, João Batista (gênio), Edson Takeshi (mago das invenções), Renato Giordano, Pedro Vicente, pessoas que para mim tiveram vital importância, seja na realização dos experimentos, ou na confecção de um dispositivo novo para me auxiliar no trabalho, ou mesmo num bate papo amigo nos momentos de dificuldades.

À minha amiga Mara Tânia que sempre tinha uma palavra amiga para ajudar a aliviar a tensão nos momentos difíceis.

Ao amigo Helber Holland pela ajuda nos ensaios do MEV. 


\section{SUMÁRIO}

\section{Página}

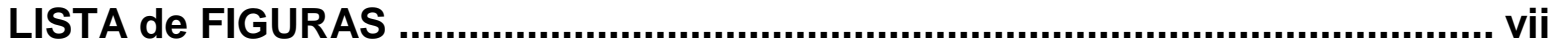

LISTA de TABELAS

LISTA de SÍMBOLOS ......................................................................................

LISTA de UNIDADES ............................................................................... xi

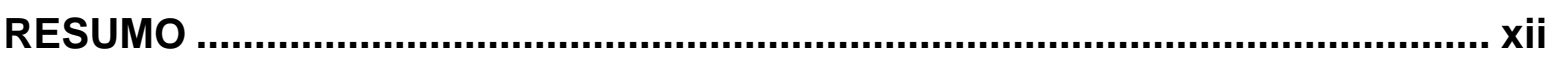

ABSTRACT

I. INTRODUÇÃO

II. OBJETIVO

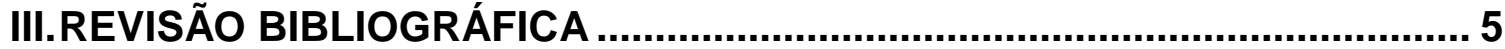

III.1. Nanotecnologia: um pouco de história.............................................. 5

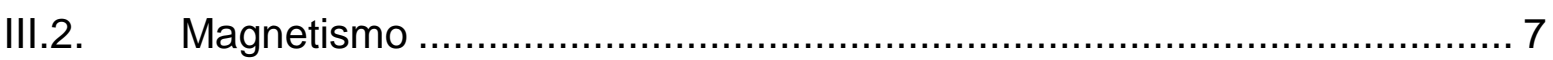

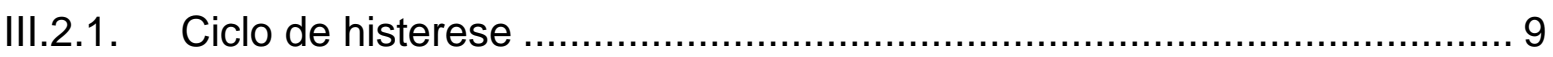

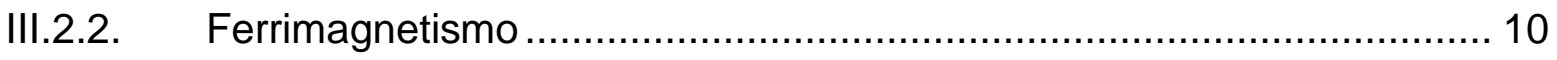

III.2.3. Superparamagnetismo o............................................................... 12

III.2.4. Fluidos magnéticos ou ferrofluidos ………...................................... 14

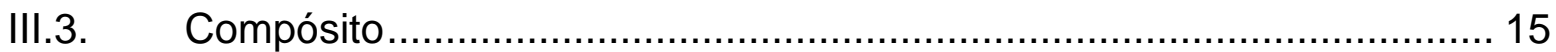

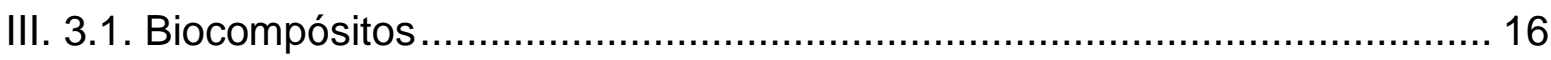

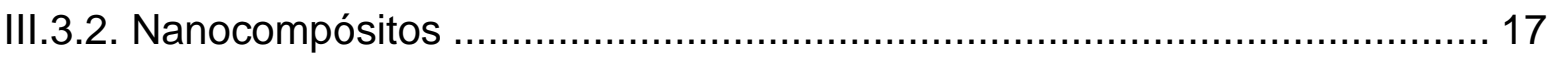

III.3.3. Biocompósito magnético .................................................................. 17

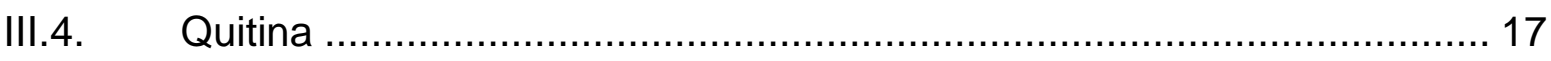

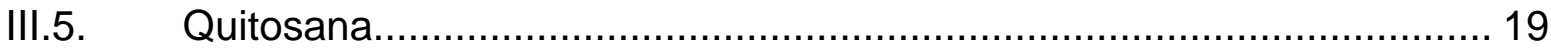

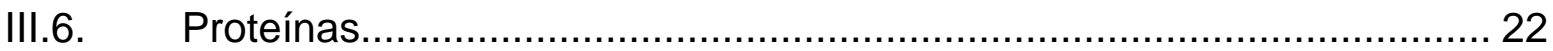

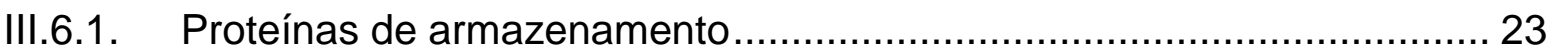

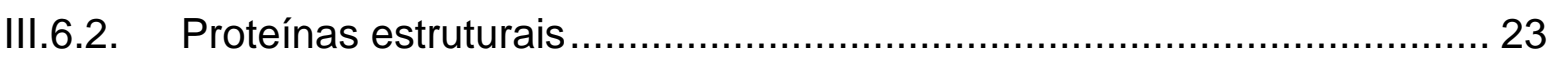

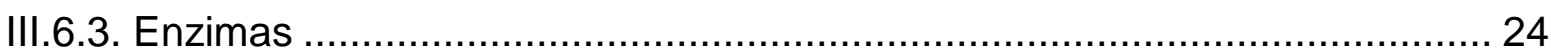




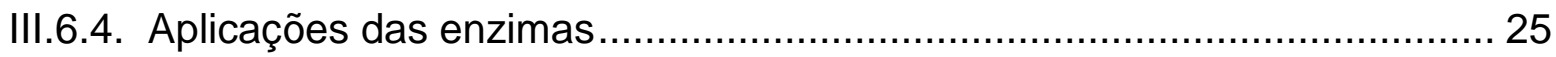

III.7. Métodos de imobilização................................................................. 26

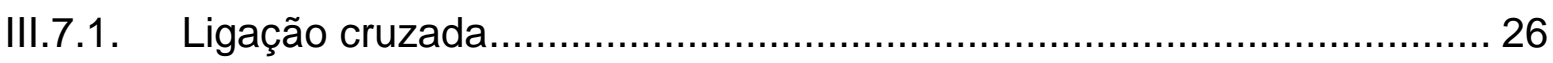

III.7.2. Adsorção física em suportes insolúveis em água ................................ 27

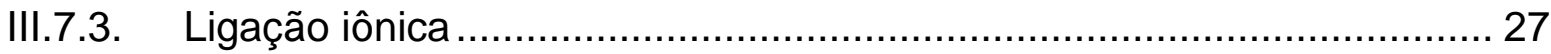

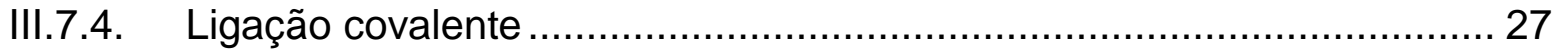

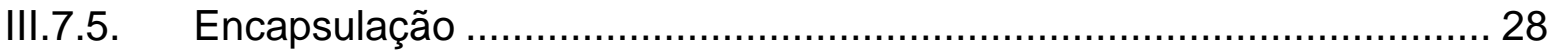

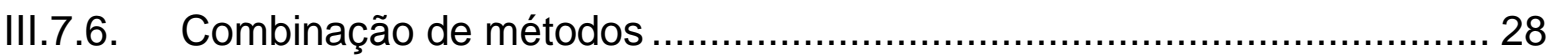

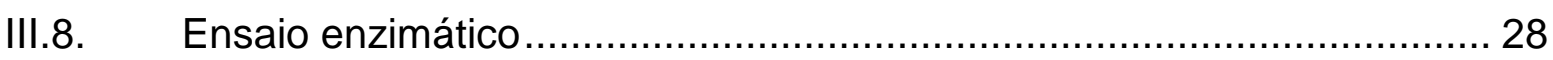

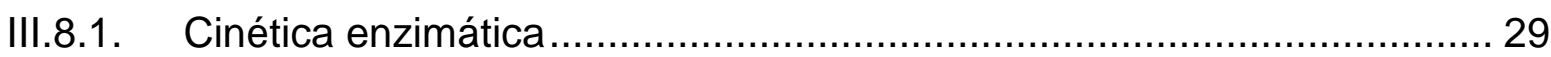

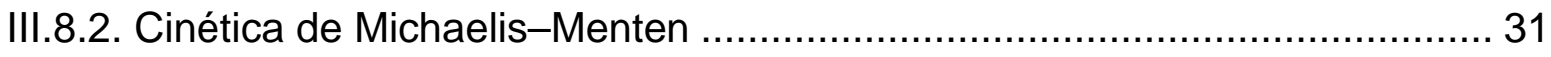

III.8.3. Gráfico de Lineweaver-Burke ou duplo recíproco ................................. 31

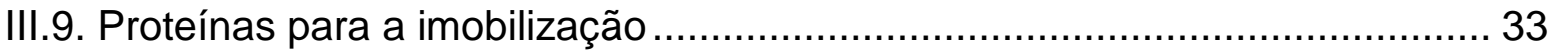

III.9.1. Albumina de soro bovino (BSA) ……............................................. 34

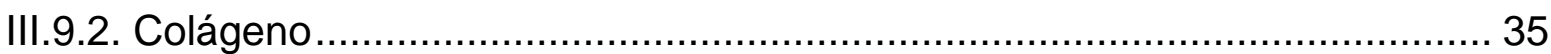

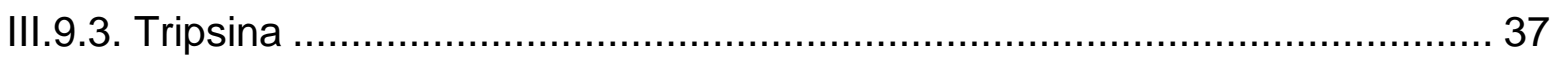

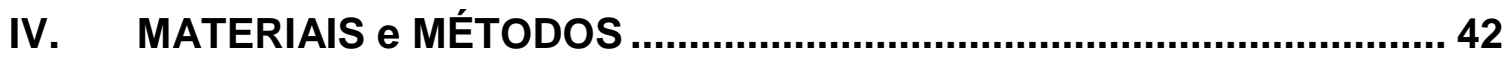

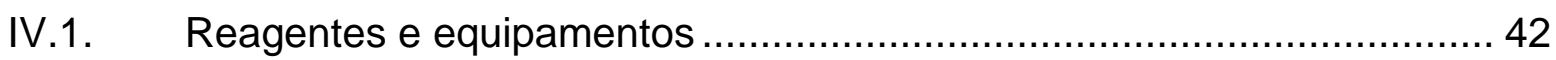

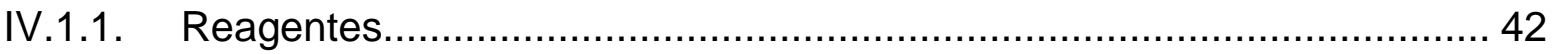

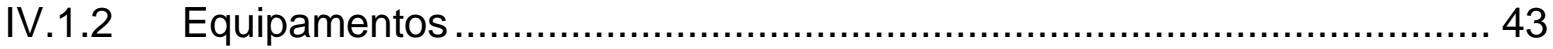

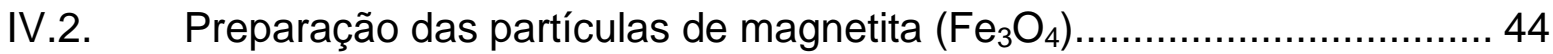

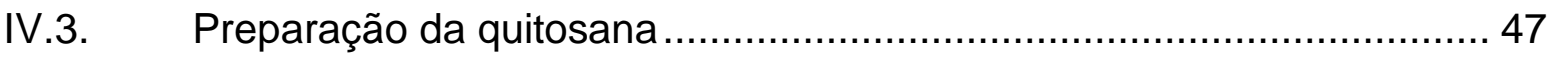

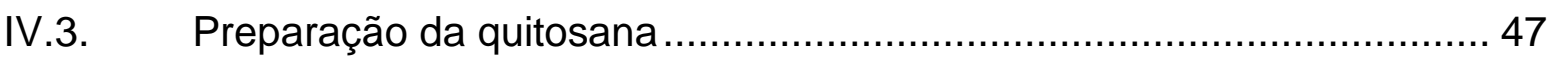

IV.4. Revestimento das partículas magnéticas de magnetita com quitosana

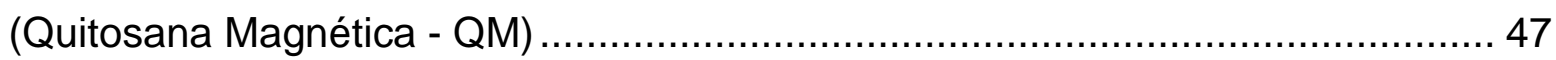

IV.5. Tratamento da superfície da quitosana magnética (QM) ........................... 49

IV.6. Reticulação e funcionalização da QM com o glutaraldeído .......................... 51

IV.7. Preparação das proteínas cargas (Prot-carga) …................................. 53

IV.8. Imobilização de proteínas na superfície das QMs funcionalizadas (QM1Glu, QM2NaGlu e QM3Glu) e não funcionalizada (QM3).

IV.8.1. Separação das fases sólida-líquida (proteína imobilizada-proteína livre,

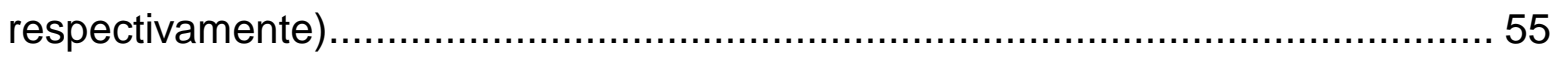

IV.8.2. Remoção da proteína não imobilizada nas partículas magnéticas ......... 55

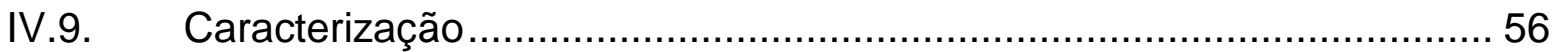


IV.9.1. Microscopia eletrônica de varredura (MEV) …................................... 56

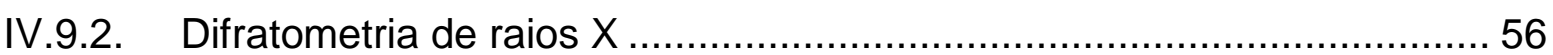

IV.9.3. Magnetometria de amostra vibrante (MAV) ….................................. 57

IV.9.4. Calorimetria exploratória diferencial (DSC) ....................................... 57

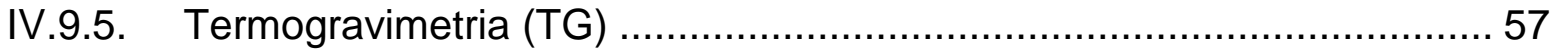

IV.9.6. Espectroscopia na região do Infravermelho por transformada de Fourier (FTIR) 57

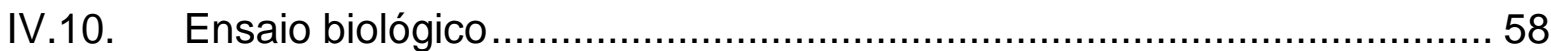

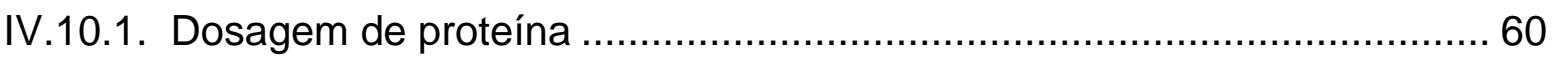

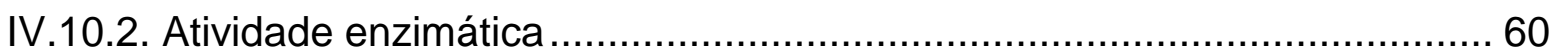

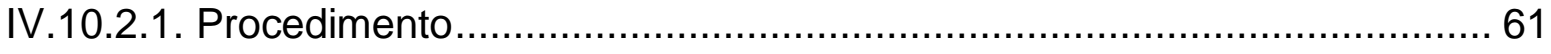

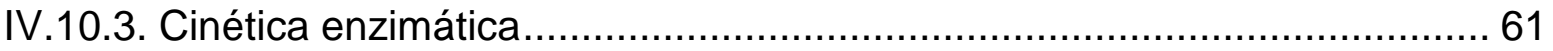

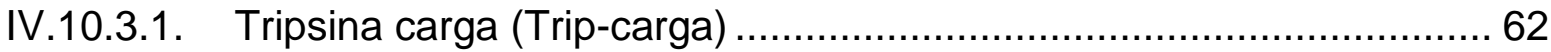

IV.10.3.2.Partículas magnéticas (QM3-Trip e QM3Glu-Trip) .............................. 63

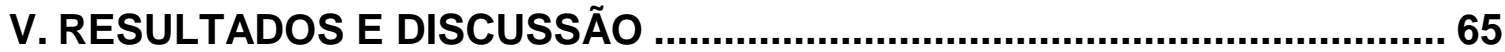

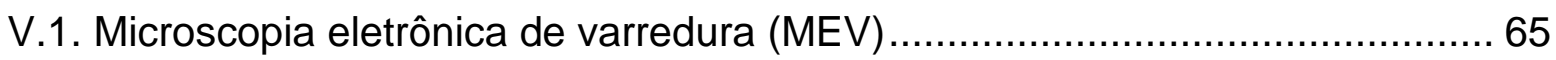

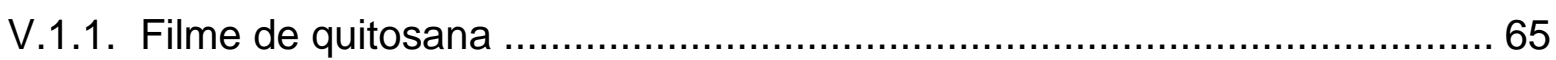

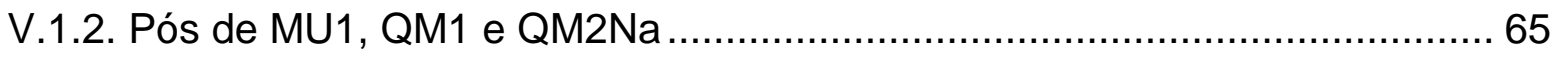

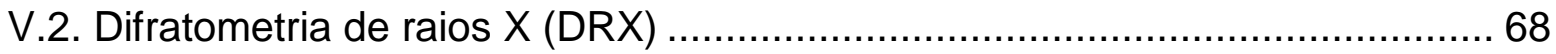

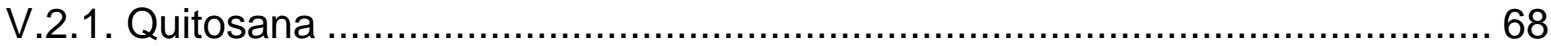

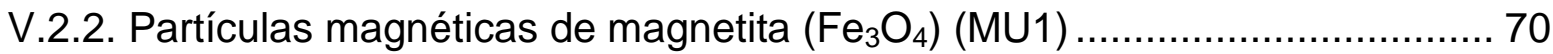

V.2.3. Quitosana magnética QM1 e QM2Na ..................................................... 71

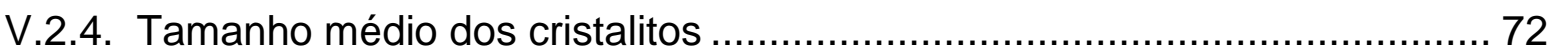

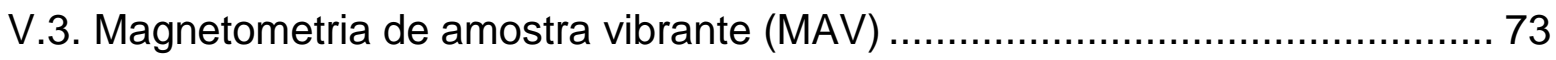

V.4. Calorimetria exploratória diferencial (DSC)............................................. 74

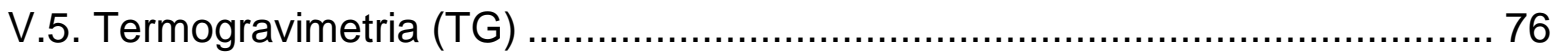

V.6. Espectroscopia de absorção na região do Infravermelho por transformada de

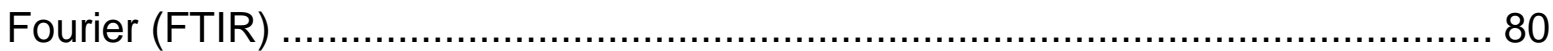

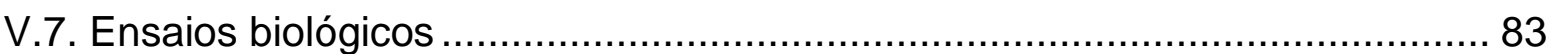

V.7.1. Tempo de incubação das proteínas $\left(2 \mathrm{mg} \cdot \mathrm{mL}^{-1}\right)$ nas partículas magnéticas 83

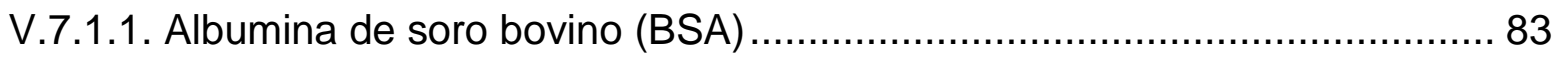

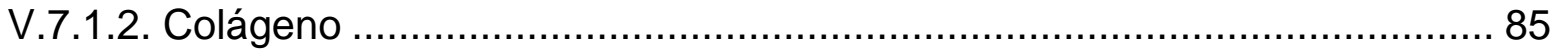

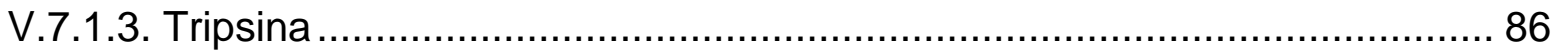

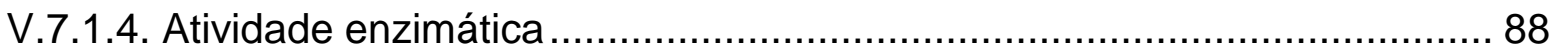




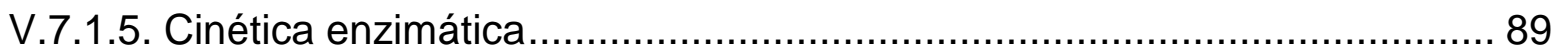

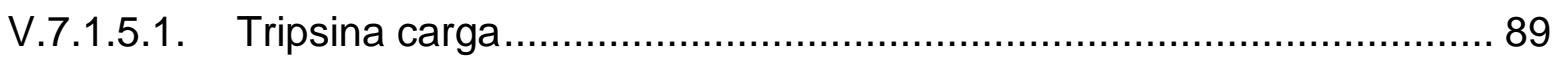

V.7.1.5.2. Partículas magnéticas (QM3-Trip) …........................................... 91

V.7.1.5.3. Partículas magnéticas (QM3Glu-Trip) .......................................... 91

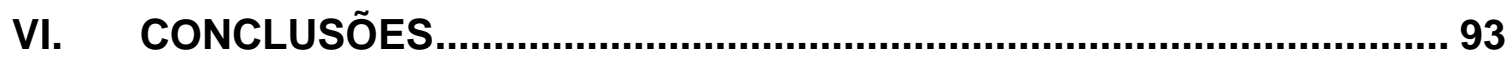

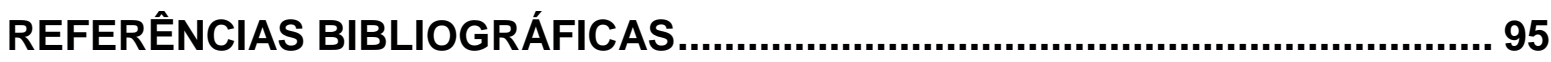




\section{LISTA de FIGURAS}

FIGURA 1 - Ciclo de Histerese.

FIGURA 2 - Ferrimagnetismo: (a) os dipolos atômicos estão alinhados anti-paralelamente e com amplitudes diferentes dentro dos domínios magnéticos; (b) spins são alinhados ao longo do campo magnético; (c) após a retirada do campo magnético, observa-se uma magnetização remanente (FIG. 6c).

FIGURA 3 - Superparamagnetismo: em partículas de monodomínio magnético o momento magnético está orientado segundo a direção definida pelo eixo de fácil magnetização da partícula: (a) sem a ação de um campo magnético os momentos magnéticos se posicionam aleatoriamente; (b) na presença de um campo magnético as partículas de monodomínio se alinham em direção ao campo magnético.

Figura 4 - Estrutura das unidades repetitivas sacarídeas da celulose (glicose), e díssacarídeas da quitina (glicopiranose), unidas pelas ligações glicosídicas $\beta-(1 \rightarrow 4)$; $n$ se refere ao grau de polimerização. 18

FIGURA 5 - Cadeia polimérica da quitosana. 20

FIGURA 6- Fórmula molecular do glutaraldeído 21

FIGURA 7 - Cadeia polimérica da quitosana reticulada pelo glutaraldeído. 22

FIGURA 8 - Formação das proteínas por meio da ligação peptídica. ... 23

FIGURA 9 - Efeito da concentração de substrato na velocidade inicial de uma reação catalisada por enzima (concentração constante). 30

FIGURA 10 - Gráfico de Lineweaver-Burk ou duplo-recíproco. 32

FIGURA 11 - Albumina de soro bovino 34

FIGURA 12 - Estrutura fibrosa do colágeno 36

FIGURA 13 - Sítio ativo da quimotripsina formando um complexo com um substrato 38

FIGURA 14 - Clivagem hidrolítica de uma ligação peptídica pela quimotripsina 40

FIGURA 15 - Hidrólise do substrato cromogênico $N$-a-benzoil -DLarginina-p-nitroanilida (BApNA) pela enzima tripsina.

FIGURA 16 - Produção de partículas magnéticas de magnetita $\left(\mathrm{Fe}_{3} \mathrm{O}_{4}\right)$. 
FIGURA 17 - Revestimento das partículas magnéticas de magnetita com a quitosana. Obtenção da QM.

FIGURA 18 - Preparação da QM para a reação com o glutaraldeído... 50

FIGURA 19 - Reticulação e funcionalização da quitosana presente nas QM com o glutaraldeído. 52

FIGURA 20 - Imobilização de proteínas na superfície das QM. 54

FIGURA 21 - Imagens de MEV do filme de quitosana obtido por dissolução com ácido acético e secagem à temperatura ambiente. Ampliação 49x e $8.000 x$. 66

FIGURA 22 - Imagem de MEV de partículas de MU1. Ampliação 10.000x.

FIGURA 23 - Imagem de MEV de partículas de quitosana magnéticas QM1. Ampliação 10.000x.

FIGURA 24 - Imagem de MEV de partículas de quitosana magnéticas QM2Na (quitosana reprecipitada com $\mathrm{NaOH}$ ). Ampliação 10.000x. 68

FIGURA 25 - Difratograma de raios $x$ do filme de quitosana. 69

FIGURA 26 - Difratograma de raios $X$ do pó MU1. 70

FIGURA 27 - Difratogramas de raios $X$ dos compósitos QM1 e QM2Na sobrepostos

FIGURA 28 - Curvas de magnetização de saturação sobrepostas das MU1, QM1 e QM2Na (a); 73

FIGURA 29 - Curvas DSC das amostras: MU1 (a); filme de quitosana (b); QM1 (c); QM2Na (d). 10ㄷ. $\mathrm{min}^{-1}, 50 \mathrm{~mL} \cdot \mathrm{min}^{-1} 1, \mathrm{~N}_{2}$. 75

FIGURA 30 - Curvas de TG (a) e DTG (b) do filme de quitosana. $10^{\circ} \mathrm{C} \cdot \mathrm{min}^{-1}$, 77

FIGURA 31 - Curvas de TG (a, b, c) e DTG (A, B, C) de MU1 (a, A), QMU1 (b, B) e QM2Na (c, C). 10ำ. $\mathrm{min}^{-1}, 50 \mathrm{~mL} \cdot \mathrm{min}^{-1} 1, \mathrm{~N}_{2}$ 79

FIGURA 32 - Espectro de absorção na região do infravermelho: (a) filme de quitosana ensaiado por técnica de reflexão (ATR); e partículas magnéticas MU1 (b); QM1 (c) e QM2Na (d), diluídas em $\mathrm{KBr}$ 80

FIGURA 33 - Curva padrão da BSA. 83

FIGURA 34 - Imobilização do albumina de soro bovino (BSA) nas partículas de quitosana magnéticas. 84 
FIGURA 35 - Imobilização do colágeno nas partículas de quitosana magnéticas.

FIGURA 36 - Imobilização da tripsina nas partículas de quitosana magnéticas em diferentes tempos de incubação.

FIGURA 37 - Atividade enzimática da tripsina nas partículas de QM3Trip e QM3Glu-Trip após várias lavagens com $\mathrm{HCl} 0,001 \mathrm{~mol} \mathrm{~L}^{-1}$, antes dos ensaios. 88

FIGURA 38 - Efeito da concentração do substrato BApNA na velocidade da reação catalisada pela tripsina (Trip-carga). 90

FIGURA 39 - Gráfico duplo-recíproco ou de Lineweaver-Burk baseado nos resultados obtidos nos ensaios com a Trip-carga 90

FIGURA 40 - Gráfico duplo-recíproco ou de Lineweaver-Burk da tripsina na QM3Glu-Trip 92 


\section{LISTA de TABELAS}

TABELA 1 - Propriedades dos materiais magnéticos. 8

TABELA 2 - Propriedades das proteínas albumina de soro bovino (BSA), colágeno e tripsina.

TABELA 3 - Tempo de incubação das QM com as proteínas (concentração $0,1 \mathrm{mg} \cdot \mathrm{mL}^{-1}$ e $2,0 \mathrm{mg} \cdot \mathrm{mL}^{-1}$ ). 53

TABELA 4 - Partículas magnéticas imobilizadas com a tripsina (180 min de contato) e lavadas com $\mathrm{HCl} 0,001 \mathrm{~mol}^{-1}$, para a retirada de enzima livre. ..... 55

TABELA 5 - Distribuição das amostras para os ensaios no espectrofotômetro UV/visível. 59

TABELA 6 - Relação enzima/substrato para o ensaio de cinética enzimática (volume final $=1000 \mu \mathrm{L}$ ). 62

TABELA 7 - Valores de intensidade dos picos de DRX e diâmetro médio (d) da amostras MU1, QM1 e QM2Na. 72

TABELA 8 - Valores de magnetização das partículas de MU1, QM1 e QM2Na. 73

TABELA 9 - Valores de magnetização das nanopartículas de MU1 e dos compósitos QM1 e QM2Na. 74

TABELA 10 - Transições térmicas do filme de quitosana, das partículas magnéticas MU1 e dos compósitos QM1 e QM2Na. 75

TABELA 11 - Caracterização por TG e DTG da quitosana, do pó de magnetita MU1e dos compósitos QM1 e QM2Na. 77

TABELA 12- Massas residuais da MU1 e dos compósitos QM1 e QM2Na ensaiadas por meio de TG. 80

TABELA 13 - Principais atribuições de bandas de absorção de infravermelho e frequências vibracionais para a quitosana, MU1, QM1 e QM2Na.81

TABELA 14 - Percentual imobilizado com variação de tempo de incubação da BSA nas partículas de quitosana magnéticas. 85

TABELA 15 - Percentual imobilizado com variação de tempo de incubação da tripsina nas partículas de quitosana magnéticas. 


\section{LISTA de SÍMBOLOS}

\begin{tabular}{cl} 
Símbolo & \multicolumn{1}{c}{ Descrição } \\
$\theta_{C}$ & Temperatura de Curie \\
$\left(\theta_{N}\right)$ & Temp. de Néel \\
$B$ & Densidade de fluxo magnético \\
$H$ & Campo magnético aplicado \\
$\chi$ & Susceptibilidade magnética
\end{tabular}

\section{LISTA de UNIDADES}

Unidade

nm Nanômetro

Descrição

[S] Concentração do substrato

[E] Concentração da enzima

$V_{0} \quad$ Velocidade inicial da reação

$\boldsymbol{K}_{m} \quad$ Constante de Michaelis-Menten; demonstra a afinidade pela enzima ao

substrato

$V_{\operatorname{máx}} \quad$ Valor máximo de velocidade indicando que a enzima está saturada

$\mathrm{kDa} \quad$ Quilodalton 


\title{
FUNCIONALIZAÇÃO DA SUPERFÍCIE DE NANOPARTÍCULAS SUPERPARAMAGNÉTICAS ENCAPSULADAS POR QUITOSANA PARA A IMOBILIZAÇÃO DE PROTEÍNAS
}

\author{
José Silva de Sousa
}

RESUMO

A nanociência e a nanotecnologia vêm abrindo inúmeros desenvolvimentos de dispositivos e sistemas em escala nanométrica, com novas organizações moleculares, propriedades e funções distintas. Nesse contexto, as nanopartículas magnéticas poliméricas são compósitos formados por materiais magnéticos com tamanhos de partículas entre 1 e $100 \mathrm{~nm}$ combinados com polímeros funcionais. São materiais bem conhecidos e têm sido amplamente estudados devido às suas aplicações em diversas áreas tecnológicas. Nas áreas biológica e médica, as aplicações incluem separação e imobilização de enzimas e proteínas, melhoria nas técnicas de imagem de ressonância magnética para diagnóstico e sistemas de liberação controlada de fármacos. Neste trabalho, proteínas foram imobilizadas na superfície de um biopolímero combinado com partículas superparamagnéticas de magnetita para formar o compósito magnético. Utilizou-se o biopolímero quitosana, reticulada e funcionalizada com glutaraldeído, aplicável em ensaios biológicos. Obtiveram-se 3 tipos de compósitos magnéticos, os quais foram nomeados QM1Glu, QM2NaGlu e QM3Glu. Foram caracterizados por difratometria de raios $\mathrm{X}$, microscopia eletrônica de varredura, magnetometria de amostra vibrante, calorimetria exploratória diferencial, termogravimetria e espectroscopia por infravermelho. Foram avaliados quanto à imobilização das proteínas albumina de soro bovino (SAB), colágeno e tripsina. $A$ imobilização das proteínas no biopolímero ocorreu em 30 min de incubação. $O$ compósito magnético de quitosana não funcionalizada (QM3) também foi avaliado. Para a tripsina verificou-se que QM3 apresentou maior potencial de imobilização do que QM3Glu. Após 30 dias, QM3-Trip e QM3Glu-Trip ainda apresentavam a tripsina ativada. Foram demonstradas a atividade e a cinética enzimática da QM3Glu-trip com o substrato BApNA. 


\title{
SURFACE FUNCTIONALIZATION OF SUPERPARAMAGNETIC NANOPARTICLES ENCAPSULATED BY CHITOSAN FOR PROTEIN IMMOBILIZATION
}

\author{
José Silva de Sousa
}

\begin{abstract}
Nanoscience and nanotechnology have opened up numerous developments of devices and systems on the nanometer scale, with new molecular organization, properties and functions. In this context, the polymeric magnetic nanoparticles are composites formed by magnetic materials with a particle size between 1 and $100 \mathrm{~nm}$ combined with functional polymers. They are well-known and have been widely studied because of its applications in various technology areas. Applications on the biological and medical areas include separation and immobilization of enzymes and proteins, improved techniques of magnetic resonance imaging and diagnostic systems for controlled drug delivery. In this work, proteins were immobilized on the surface of a biopolymer combined with superparamagnetic particles of magnetite. The biopolymer chitosan was used, cross-linked and functionalized with glutaraldehyde, applicable to the biological assays. Three types of magnetic composites were obtained, which were called QM1Glu, QM2NaGlu and QM3Glu. They were characterized by X-ray diffraction, scanning electron microscopy, vibrating sample magnetometry, differential scanning calorimetry, thermogravimetry and infrared spectroscopy. They were evaluated concerning the immobilization of the proteins bovine serum albumin (BSA), collagen and trypsin. The study showed that the immobilization of proteins on the biopolymer occurred in $30 \mathrm{~min}$ of incubation. The magnetic composite of nonfunctionalized chitosan (QM3) was also evaluated. For trypsin, it was found that the immobilization potential of QM3 was higher than that observed for QM3Glu. After 30 days, the trypsin of the QM3-Trip and QM3Glu-Trip was still with activity. The activity and the enzyme kinetics of the QM3Glu-Trip with the substrate BApNA were demonstrated.
\end{abstract}




\section{INTRODUÇÃO}

A nanociência e a nanotecnologia vem abrindo novos horizontes para inúmeros desenvolvimentos, possibilitando a criação e manipulação de materiais, dispositivos e sistemas em escala nanométrica $\left(10^{-9} \mathrm{~m}\right.$, um bilionésimo do metro), com novas organizações moleculares, propriedades e funções distintas [CAMARGO et al., 2009].

Nesse contexto, as nanopartículas magnéticas poliméricas são compósitos magnéticos formados por materiais magnéticos com tamanhos de partículas entre 1 e $100 \mathrm{~nm}$ combinados com polímeros funcionais [BERRY e CURTIS, 2003; GUBIN et al., 2005]. São materiais amplamente estudados devido às suas aplicações em diversas áreas, tais como: biológica, médica e ambiental. As aplicações incluem separação e imobilização de enzimas e proteínas, melhoria nas técnicas de imagem de ressonância magnética para diagnóstico, e sistemas de liberação controlada de fármacos, entre outras [PANKHURST et al. 2003; NAIR e LAURENCIN, 2007].

Um material magnético muito utilizado na obtenção de compósitos magnéticos é a magnetita $\left(\mathrm{Fe}_{3} \mathrm{O}_{4}\right)$, um imã natural em escala macro. Ao reduzir o tamanho das partículas de magnetita, à proporções nanométricas, torna-se superparamagnética, magnetizando-se somente quando submetida a um campo magnético externo, não devendo reter o magnetismo após a remoção desse campo [BERRY e CURTIS, 2003; HONG et al., 2007].

A quitosana, um biopolímero, vem sendo utilizada na combinação com as nanopartículas magnéticas [ $\mathrm{LI}$ et al., 2008] a fim de formar um compósito magnético funcional. É um aminopolissacarídeo biodegradável, hidrofílico e biocompatível [NAIR e LAURENCIN, 2007] obtido, principalmente, a partir da desacetilação alcalina da quitina, embora possa ocorrer naturalmente em pequenas quantidades a partir de certas espécies de fungos. A sua cadeia polimérica é formada predominantemente por unidades de 2-amino-2-desoxi-D- 
glicopiranose e em quantidade menor de unidades de 2-acetamido-2-desoxi-Dglicopiranose [FAN et al., 2009]. Os grupos funcionais amino e hidroxila da cadeia polimérica capacitam-na a formar complexos com íons metálicos e biomoléculas. $\mathrm{O}$ grupo acetamida $\left(-\mathrm{NHCOCH}_{3}\right)$ é proveniente do processo de desacetilação da quitina.

O compósito magnetita-quitosana pode ser obtido por meio da reação de soluções de partículas de magnetita e de biopolímero previamente dissolvido em meio ácido. Essa reação química promove a coordenação entre os íons de ferro e os grupos reativos presentes na cadeia polimérica, formando o compósito magnético [HERNÁNDEZ et. al., 2009; BHATIA e RAVI, 2000]. O grupamento amino $\left(-\mathrm{NH}_{2}\right)$, muito reativo, fica exposto ao longo de sua cadeia sendo responsável pela formação dos sítios ativos que possibilitarão inúmeras aplicações tecnológicas [BHATTARAI et al., 2008].

Entre as aplicações cita-se a magneto-hipertermia, um procedimento terapêutico que envolve a introdução de nanopartículas superparamagnéticas revestidas com um biomaterial polimérico, numa determinada região do corpo comprometida por uma neoplasia. Estas atravessam a barreira endotelial e se acumulam especificamente nas células-alvo. Aplicando-se um campo magnético externo a temperatura local se eleva, causando danos às células cancerosas, eliminando-as, sem causar alterações aos tecidos normais circunvizinhos [PAVON e OKAMOTO, 2007].

O compósito quitosana/magnetita tem sido desenvolvido como carreador efetivo em sistemas de liberação controlada de drogas, sendo funcionalizadas para um melhor direcionamento ao tecido-alvo, prevenindo os efeitos colaterais [TARTAJ et al., 2003].

Além disso, os compósitos magnéticos com área superficial específica para a imobilização de grande quantidade de biomoléculas fornecem uma alternativa para a imobilização de anticorpos e enzimas, utilizados como imunossensores aplicados em ensaios imunológicos e processos de separação celular, separação seletiva, possibilidade de diagnóstico clínico em menor tempo, evitando-se as várias etapas de análises bioquímicas e possivelmente, a um custo mais baixo que nos exames tradicionais [WANG e TAN, 2007].

As enzimas são macromoléculas de natureza proteica formadas por longas sequências de aminoácidos. São capazes de catalisar reações biológicas, 
sendo encontradas naturalmente em todos os seres vivos. Elas viabilizam as atividades celulares, quebrando moléculas ou participando da formação de novos produtos. São compostos de elevada especificidade aos substratos, moléculas sob os quais atuam [ALBERTS et al., 1999a].

Muitas vezes, o seu emprego é inviabilizado devido a diversos fatores, como o seu custo elevado, a sua rápida inativação em condições fisiológicas, e a alta sensibilidade à ação de proteases endógenas e inibidores naturais. Por esse motivo, o desenvolvimento de ferramentas que permitam torná-las reutilizáveis, mantendo a sua atividade catalítica por um período longo, é de grande interesse. Os pesquisadores têm empregado grandes esforços nesse sentido.

A imobilização enzimática é uma forma para superar essas limitações, por meio dela a estrutura da enzima se mantém estabilizada prolongando a sua "vida útil" [SPAHN e MINTEER, 2008]. 


\section{OBJETIVO}

A proposta desse trabalho é obter nanopartículas magnéticas de magnetita revestidas com a quitosana, funcionalizada por meio da reação com o glutaraldeído, e verificar a potencialidade na imobilização de proteínas e enzimas. 


\section{REVISÃO BIBLIOGRÁFICA}

\section{III.1. Nanotecnologia: um pouco de história}

Partir do pequeno, do menor, do minúsculo, até a reorganização dos átomos para o desenvolvimento de novas tecnologias, alimentos, materiais ou aparelhos, é a nanotecnologia. Uma ciência que começou a ser difundida no século passado, na década de 50, e que aos poucos foi ganhando espaço.

Em 1959, o físico e pesquisador americano Richard Feynman defendeu que, no futuro, seria possível visualizar, estudar, controlar e manipular a matéria, a partir de sua menor estrutura [FEYNMAN, 1959]. Ele vislumbrou um novo universo a partir de estruturas de ínfimas dimensões, e previu o desenvolvimento do que hoje se denomina nanociência e nanotecnologia [DREXLER, 1981].

A expressão "nanotecnologia" foi utilizada originalmente em meados da década de 70 para descrever técnicas que permitiam a construção de materiais de proporções extremamente reduzidas, com dimensões inferiores a 100 nanômetros [FANFAIR, 2005]. Em 1986, DREXLER, (1981) popularizou a idéia de nanotecnologia propondo a construção átomo a átomo de materiais e dispositivos úteis à vida humana.

Em 1981, pesquisadores do laboratório da IBM em Zurique, na Suíça, desenvolveram microscópios que possibilitaram a visualização e a manipulação individual dos átomos. Definitivamente iniciava-se o futuro previsto por Feynman. Em 1989, efetivamente manipularam átomos de xenônio para escrever as primeiras letras nanométricas, imprimindo as iniciais da IBM [FANFAIR, 2005].

A previsão feita por Feynman se tornou realidade, despertando um enorme interesse científico e vultosos investimentos econômicos para o seu desenvolvimento.

Devido à diversificação de suas aplicações, a nanotecnologia tem seu espaço garantido no mundo todo, sendo projetado para o ano de 2015 um 
mercado de US\$ 1 trilhão de dólares, em peças e sistemas com algum tipo de nanotecnologia embutida.

No intervalo que compreende dimensões da ordem de 1 a $100 \mathrm{~nm}$, os materiais podem ter propriedades substancialmente diferentes, quando comparado aos de tamanho normal, devido ao aumento substancial da área superficial da massa e aos efeitos quânticos, levando a mudanças significativas em suas propriedades químicas e físicas [PEREIRA et al., 2006]

As aplicações implicam no desenvolvimento de novos materiais, tais como os filmes muito finos usados em catálise e eletrônica, os nanotubos de duas dimensões, os nanofios utilizados em sistemas ópticos e magnéticos, nanosensores [VO-DINH et al., 2001] e as nanopartículas utilizadas em cosméticos, produtos farmacêuticos, biológicos, revestimentos, componentes eletrônicos e de informática [PAVON e OKAMOTO, 2007; TOMA, 2005].

As nanopartículas magnéticas têm enorme potencial em diversas vertentes tecnológicas. Podem ser utilizadas na fabricação de nanocompósitos magnéticos, na preparação de fluidos magnéticos e magnetolipossomas [SALATA, 2004]. De um modo geral, as aplicações biomédicas das nanopartículas magnéticas compreendem a administração interna (in vivo) e externa no organismo (in vitro).

Para que a aplicação em um meio biológico se torne viável, é necessário que se comporte como um biomaterial, de tal forma que seja reconhecido como parte integrante do sistema, evitando-se possíveis reações de defesa do sistema imunológico [VO-DINH et al., 2001].

Um nanomaterial biologicamente compatível e com propriedades magnéticas torna-se uma ferramenta importante no monitoramento interno de tecidos e órgãos de animais e humanos, melhorando a qualidade no contraste da imagem por ressonância magnética [HONG et al., 2007], ou agindo diretamente sobre as células cancerosas, transportando e liberando fármacos que atuarão com precisão na área afetada, ou mesmo participando de sua destruição, por meio da magnetohipertermia [FORTINA, et al., 2005; HUGHES, 2005; ZHAROV et al., 2005].

Os biomateriais podem ser funcionalizados por meio de reagentes químicos [NAYAK et al., 2009] transformando-se em suportes eficazes para a imobilização de biomoléculas (por exemplo, enzimas), potencializando sua 
participação ativa nos processos de biocatálises enzimáticas [RICCA e CUTTING, 2003].

Para desenvolver um nanosistema magnético biologicamente ativo [GAO et al., 2009; NAIR e LAURENCIN, 2007] é preciso conhecer suas propriedades magnéticas, seus parâmetros físicos, tal como o tamanho da partícula, compreender o seu comportamento no contato com os organismos, assim como conhecer a biomolécula que deverá ser incorporada e que desempenhará alguma função específica.

Neste trabalho, algumas particularidades serão discutidas ao longo desse trabalho, do estudo do comportamento magnético dos materiais à formação do nanobiocompósito magnético constituído de nanopartículas magnéticas de magnetita encapsuladas com a quitosana, tendo proteínas imobilizadas em sua superfície.

\section{III.2. Magnetismo}

O magnetismo é o fenômeno físico que consiste nas forças de atração e repulsão exercidas por materiais devido à presença de cargas elétricas em movimento.

Desde a antiguidade percebeu-se que determinados materiais tinham a capacidade de se atrair. Esse comportamento foi observado pela primeira vez numa região da Ásia, próximo à Turquia, chamada Magnésia, e por esse motivo o minério estudado foi denominado magnetita.

O magnetismo se apresenta nas formas mais diversas, e embora a séculos os chineses já usassem imãs para se orientar, somente em 1600, William Gilbert, médico da corte inglesa, publicou seu tratado de magnetismo, onde ele apresentou pela primeira vez a hipótese que a Terra se comporta como um enorme dipolo magnético [WRIGHT, 1975; LANGLAIS et al., 2009].

A melhor forma de introduzir os diferentes tipos de magnetismo é descrever como os materiais respondem a um campo magnético. Os materiais magnéticos são classificados em 6 grupos, de acordo com a propriedade magnética: diamagnéticos, paramagnéticos, ferromagnéticos, antiferromagnéticos, ferrimagnéticos e superparamagnéticos (TAB 1) [JUDY, 1996; SINNECKER, 2000]. 
TABELA 1 - Propriedades dos materiais magnéticos

\begin{tabular}{|c|c|c|c|c|}
\hline Classe & $\begin{array}{c}\text { Temperatura } \\
\text { Crítica }\end{array}$ & $\begin{array}{c}\text { Magnitude da } \\
\text { Susceptibilidade } \\
\text { Magnética }\end{array}$ & Estrutura Atômica & Exemplos \\
\hline Diamagnética & --- & $\sim-10^{-6}<\chi<-10^{-5}$ & Átomos não têm momento de dipolo permanente & $\begin{array}{l}\mathrm{Ag}, \mathrm{Au}, \mathrm{C}, \mathrm{H} \\
\mathrm{Cu} \mathrm{Si}, \mathrm{Zn}\end{array}$ \\
\hline Paramagnética & --- & $\sim 10^{-5}<\chi<10^{-3}$ & $\begin{array}{c}\text { Átomos têm momento de dipolo permanente, mas, } \\
\text { momentos adjacentes não interagem }\end{array}$ & $\begin{array}{l}\text { Al, } \mathrm{Cr}, \mathrm{Mn}, \\
\mathrm{Pt}, \mathrm{Ta}, \mathrm{Ti}, \mathrm{W}\end{array}$ \\
\hline Ferromagnética & $\begin{array}{l}\text { Temp. de } \\
\text { Curie }\left(\boldsymbol{\theta}_{C}\right)\end{array}$ & $>10^{-3}$ & $\begin{array}{l}\text { Átomos têm momento de dipolo permanente, e interagem, } \\
\text { ocasionando alinhamento paralelo }\end{array}$ & $\begin{array}{l}\mathrm{Ni}, \mathrm{Fe}, \mathrm{Co} \\
\mathrm{NiFe}, \mathrm{NdFeB}\end{array}$ \\
\hline Antiferromagnética & $\begin{array}{l}\text { Temp. de } \\
\text { Néel }\left(\boldsymbol{\theta}_{N}\right)\end{array}$ & $\sim 10^{-5}<\chi<10^{-3}$ & $\begin{array}{l}\text { Átomos têm momento de dipolo permanente, e interagem, } \\
\text { ocasionando alinhamento antiparalelo }\end{array}$ & $\begin{array}{l}\mathrm{MnO}, \mathrm{NiO} \\
\mathrm{FeCO}_{3}\end{array}$ \\
\hline Ferrimagnética & $\begin{array}{l}\text { Temp. de } \\
\text { Curie }\left(\boldsymbol{\theta}_{C}\right)\end{array}$ & $10^{-2}<\chi>.10^{6}$ & $\begin{array}{l}\text { Átomos têm momento de dipolo permanente, e interagem, } \\
\text { ocasionando alinhamento antiparalelo desigual }\end{array}$ & $\begin{array}{l}\mathrm{Fe}_{3} \mathrm{O}_{4}, \mathrm{y}-\mathrm{Fe}_{2} \mathrm{O}_{3} \\
\text { Ferritas }\end{array}$ \\
\hline Superparamagnética & $\begin{array}{l}\text { Temp. de } \\
\text { Curie }\left(\boldsymbol{\theta}_{C}\right)\end{array}$ & $>10^{-3}$ & $\begin{array}{l}\text { Átomos têm momento de dipolo permanente, e interagem, } \\
\text { ocasionando alinhamento }\end{array}$ & $\begin{array}{l}\mathrm{Fe}_{3} \mathrm{O}_{4}, \mathrm{y}-\mathrm{Fe}_{2} \mathrm{O}_{3}, \\
\quad \text { Ferritas }\end{array}$ \\
\hline
\end{tabular}

Fonte: ZALICH, 2005 
Nesse trabalho utilizou-se a magnetita $\left(\mathrm{Fe}_{3} \mathrm{O}_{4}\right)$, um imã natural com propriedade ferrimagnética, a qual em partículas de tamanho nanométrico apresentam característica superparamagnética. Dessa forma, essas duas propriedades importantes e a histerese magnética são discutidas detalhadamente a seguir.

\section{III.2.1. Ciclo de histerese}

A resposta dos domínios magnéticos frente a ação de um campo magnético externo aplicado $(H)$ pode ser descrita através de uma curva denominada ciclo de histerese (FIG. 1).

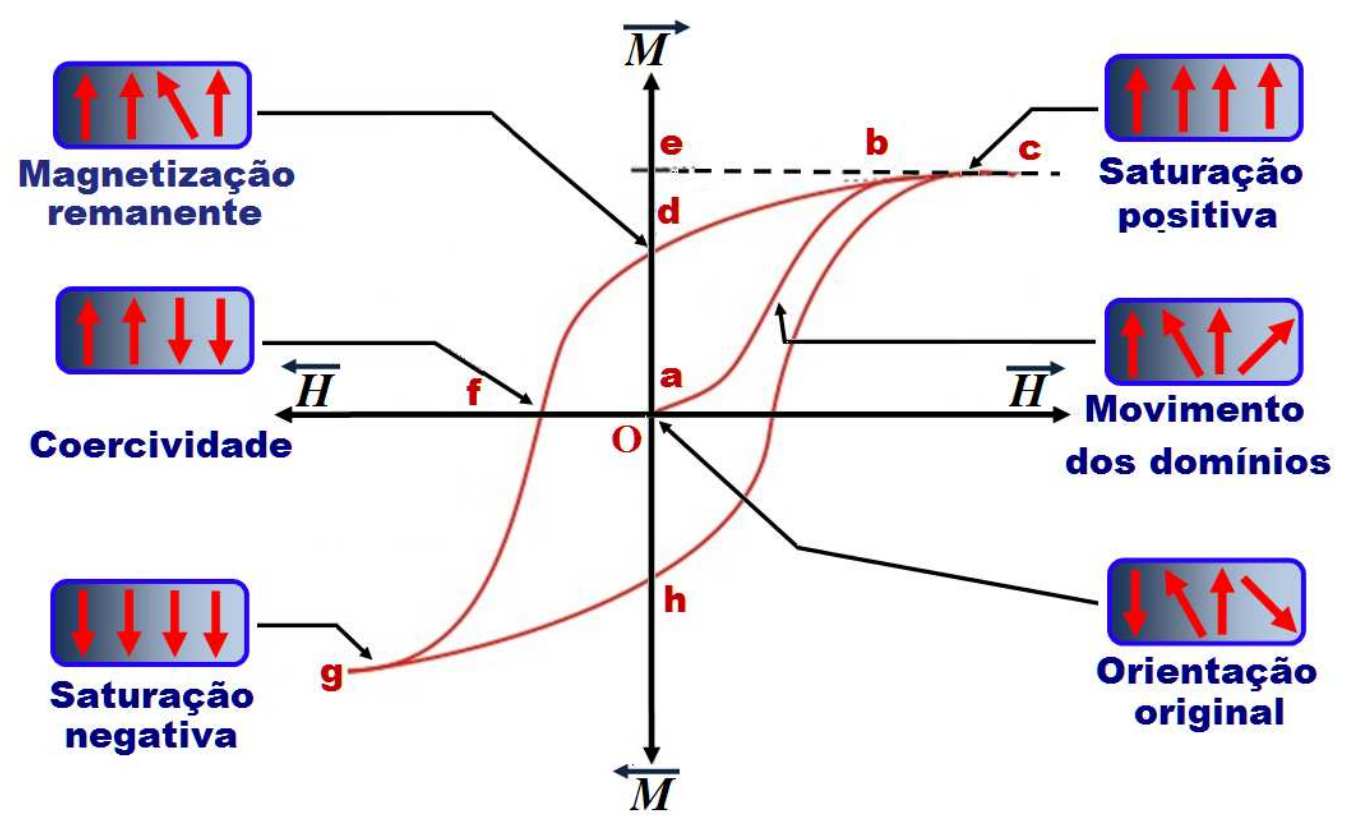

FIGURA 1 - Ciclo de Histerese

Fonte: adaptação da referência SUNG e RUDOWICZ, 2010

A curva "cdfgha" para a magnetização versus campo magnético aplicado $(\boldsymbol{M} \times \boldsymbol{H})$, representa um ciclo de histerese magnética ideal para um dado material. Inicialmente esse material apresenta seus domínios orientados aleatoriamente (ponto $\mathrm{O}$ ). Aplicando-se um campo magnético externo, os domínios se orientam na direção do campo (segmento "ab"), gerando uma 
magnetização total não nula, que aumenta rapidamente e tende a uma saturação (ítem "c"). A remoção do campo magnético ("e" = 0) não elimina completamente a magnetização adquirida, e uma magnetização remanente é observada ("d"). A extrapolação do segmento "bc" até o eixo de magnetização (ponto "e"), fornece os dados da magnetização espontânea para campos magnéticos nulos. Aplicando-se um campo magnético com polaridade oposta provoca-se uma nova reorientação dos dipolos magnéticos, até uma situação em que a magnetização resultante se anule ("f"). O campo magnético necessário para que isso ocorra é denominado de força coercitiva. Se o campo elétrico aumenta na direção negativa até "g", uma nova rotação dos dipolos ocorrerá alinhando-se nesta direção, conduzindo a uma nova situação de saturação, desta vez em sentido oposto. Os domínios podem experimentar uma nova reorientação se o campo for revertido, segmento "gha", e o ciclo de histerese se repetirá [SUNG e RUDOWICZ, 2010].

A aplicação de campos magnéticos alternados dá origem ao ciclo de histerese, como ilustrado na FIG. 1, que é uma característica fundamental dos materiais magnéticos. É preciso ser dito que o que caracteriza um material magnético não é o fato de este ter uma magnetização espontânea, mas sim de esta polarização poder ser revertida por meio da aplicação de um campo externo. Em suma, a histerese magnética reflete o fato de que a magnetização sofre um atraso em sua resposta em relação ao campo magnético aplicado [SUNG e RUDOWICZ, 2010].

\section{III.2.2. Ferrimagnetismo}

Os materiais ferrimagnéticos possuem sub-redes de íons metálicos com o alinhamento dos dipolos magnéticos orientados antiparalelamente, e com magnitudes diferentes, resultando em um momento magnético diferente de zero, inclusive na ausência de um campo magnético externo (FIG. 2a) [GATTESCHI et al., 2004].

Os momentos dipolo magnéticos nos materiais ferrimagnéticos são organizados em domínios, e são classificados como um subgrupo dos materiais antiferromagnéticos, onde cada sub-rede pode ser tratada como um material ferromagnético, e a diferença entre os momentos de dipolo magnético das subredes resultam na magnetização. 
Materiais ferrimagnéticos se comportam como materiais paramagnéticos a altas temperaturas, no entanto, igual aos ferromagnéticos, abaixo da Temperatura de Curie $\left(\theta_{C}\right)$, apresentam magnetização espontânea e similaridade na magnitude da susceptibilidade magnética $(\chi)$. Na presença do campo magnético, alinham-se na direção e sentido do campo aplicado, apresentando valores altos e positivos de susceptibilidade magnética $10^{-2}<\chi>10^{6}$ (FIG. 2b) [ABARRA et al., 2001]. Após a retirada do campo magnético, observa-se a magnetização remanente (FIG. 2c).

A diferença entre um material ferrimagnético e um antiferromagnético é que a magnitude ou o número de momentos das sub-redes não é igual [ABARRA et al., 2001].

(a)

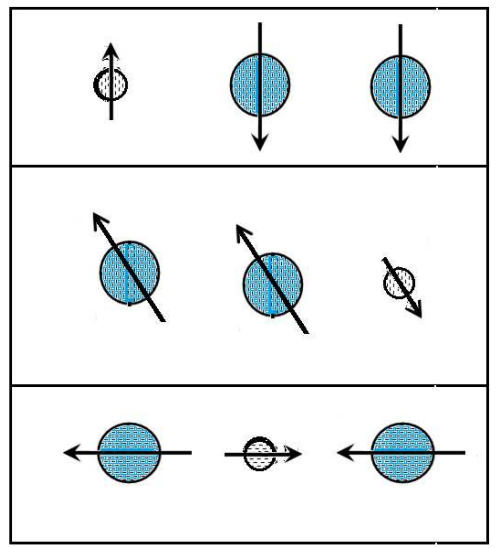

(a)

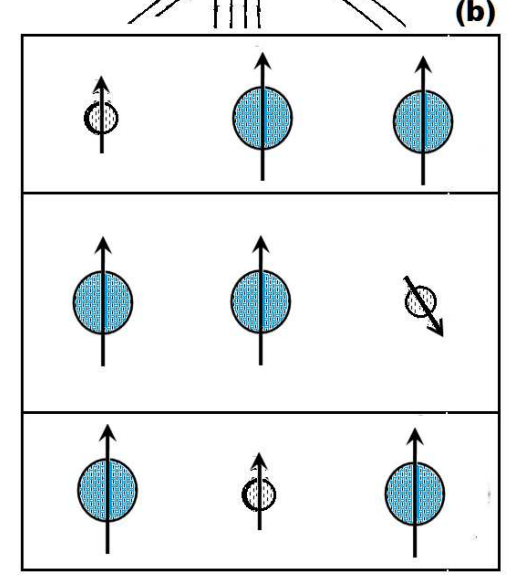

(b)

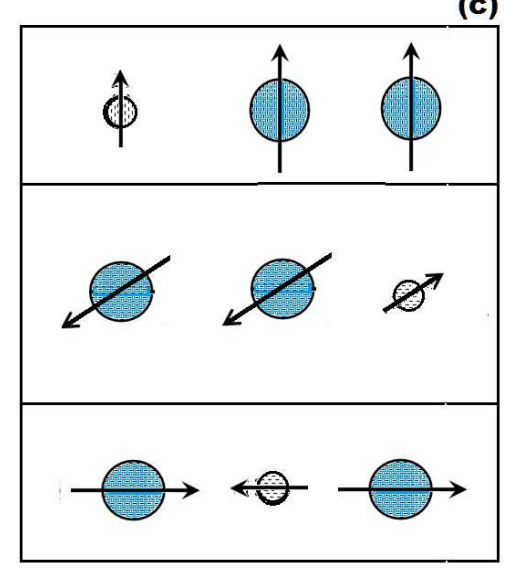

(c)

FIGURA 2 - Ferrimagnetismo: (a) os dipolos atômicos estão alinhados antiparalelamente e com amplitudes diferentes dentro dos domínios magnéticos; (b) spins são alinhados ao longo do campo magnético; (c) após a retirada do campo magnético, observa-se uma magnetização remanente (FIG. 6c).

A magnetita $\left(\mathrm{Fe}_{3} \mathrm{O}_{4}\right)$ é um óxido com comportamento ferrimagnético. Apresenta estrutura cristalina cúbica de face centrada, do tipo espinélio normal ou invertido, e magnetização espontânea, como resultado da interação entre as duas sub-redes ordenadas de forma ferromagnética [LI et al., 2007; SZNAJD, 2006]. 
A estrutura apresenta como característica o empacotamento cúbico de face centrada (cfc) com 32 íons de oxigênio, isto é, cada célula unitária contém 8 moléculas do tipo $\mathrm{M}^{2+} \mathrm{Fe}^{3+}{ }_{2} \mathrm{O}_{4}$, onde $\mathrm{M}$ representa um metal divalente. Além disso, é constituído por 64 sítios tetraédricos e 32 sítios octaédricos, dos quais apenas 8 tetraédricos e 16 octaédricos são preenchidos. De acordo com a ocupação dos sítios, a estrutura pode ser classificada como espinélio direto (metal divalente nos sítios tetraédricos e $\mathrm{Fe}^{3+}$ nos octaédricos), inverso (nos sítios tetraédricos apenas $\mathrm{Fe}^{3+}$ e nos octaédricos o metal divalente e o $\mathrm{Fe}^{3+}$ ) ou misto (ambos os sítios com proporções variadas dos metais relacionados) [SANTANA et al.,2008; ZHOU et al., 1995].

\section{III.2.3. Superparamagnetismo}

Os materiais magnéticos em escala macroscópica são caracterizados pelo alinhamento paralelo, ou antiparalelo, de seus momentos magnéticos em escala atômica, delimitados por paredes imaginárias em regiões denominadas domínios magnéticos. As paredes entre esses domínios podem ser movidas pela aplicação de um campo magnético, e é esse movimento que dá origem à curva de histerese nos materiais magnéticos [CULLITY, 1972; HUBER, 2005]

Quando o tamanho das partículas é reduzido à dimensões nanométricas $(\sim 14 \mathrm{~nm})$, o confinamento dos momentos magnéticos em parede de domínio magnético torna-se termodinamicamente desfavorável levando a formação de cristais de único domínio os quais são classificados como superparamagnéticos [CULLITY, 1972; THOREK et al., 2006].

O tamanho característico dos domínios magnéticos varia de material para material, e geralmente é da ordem de dezenas de nanometros. Normalmente, se uma partícula é menor que o tamanho do seu domínio ocorrerá o fenômeno de monodomínio magnético [HUBER, 2005].

O termo superparamagnetismo foi introduzido por Bean e Livingston em 1959 para descrever o comportamento magnético de partículas magnéticas de dimensões em escala nanométrica [ORTEGA et al., 2010].

A submissão dos materiais com propriedades superparamagnéticas à ação de um campo magnético externo induzem seus momentos magnéticos [FERGUSON et al., 2009], que se encontram posicionado aleatoriamente (FIG. 3a), a se direcionarem no sentido do campo aplicado (FIG. 3b). 
O momento induzido na mesma direção do campo aplicado aumenta com o aumento do campo magnético [HUBER, 2005]. Esse processo é contínuo, e se prolonga até que os spins do material estejam orientados, alcançado o valor máximo de magnetização chamado magnetização de saturação [HOFMANNAMTENBRINK et al., 2009].

Com a remoção do campo magnético, o movimento Browniano é suficiente para dispersar as orientações resultando na remanência magnética zero. As forças Browniana também evitam a agregação das nanopartículas devido a atração magnética na solução. [THOREK et al., 2006].

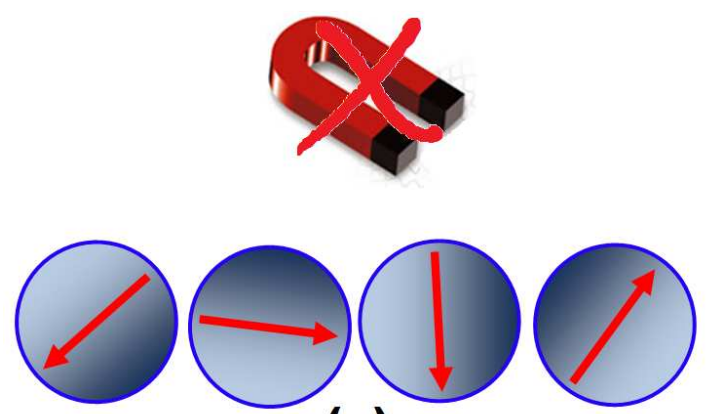

(a)

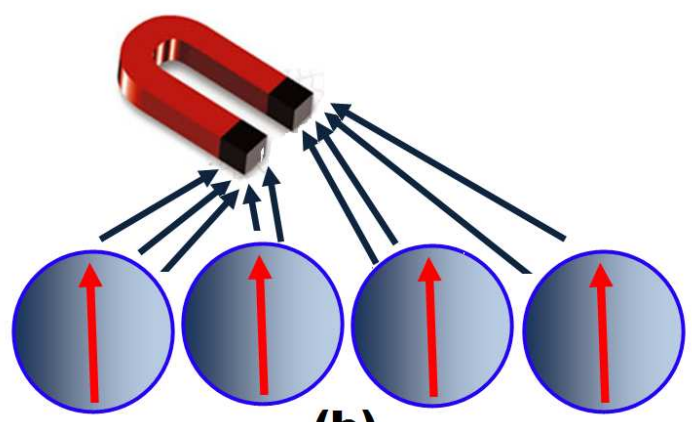

(b)

FIGURA 3 - Superparamagnetismo: em partículas de monodomínio magnético o momento magnético está orientado segundo a direção definida pelo eixo de fácil magnetização da partícula: (a) sem a ação de um campo magnético os momentos magnéticos se posicionam aleatoriamente; (b) na presença de um campo magnético as partículas de monodomínio se alinham em direção ao campo magnético.

Fonte: adaptação da referência DIAS et al., 2011.

As pesquisas e os desenvolvimentos nanotecnológicos recentes envolvendo as partículas magnéticas para aplicação em biomedicina criaram oportunidades únicas no combate de um dos maiores desafios da medicina moderna, a cura de doenças cancerosas. As nanopartículas esféricas de monodomínio de magnetita têm sido muito relatadas com esse propósito, pois o seu formato esférico tornou-a favorável às aplicações no corpo humano [NEDKOV et al., 2008]. 
O aprimoramento no controle dos processos de síntese e caracterização dos sistemas magnéticos tornou possível o acesso a informações do mundo nanomateriais magnéticos, até então desconhecido, e é o ponto de partida de desenvolvimentos nanotecnológicos fundamentais, como os ferrofluidos.

\section{III.2.4. Fluidos magnéticos ou ferrofluidos}

O interesse tecnológico pelo fluido magnético iniciou-se na década de 60 , e os seus benefícios foram percebidos imediatamente, quando cientistas da NASA tentaram criar combustíveis para veículos espaciais que pudessem ser controlados na ausência de gravidade. A solução encontrada foi moer partículas magnéticas e dispersá-las no combustível, de tal modo que pudessem ser direcionadas por meio da aplicação de um campo magnético. Desde então, as técnicas de síntese se aperfeiçoaram, e hoje se produzem fluidos magnéticos das mais diferentes formas e características, usadas nas mais diversas aplicações tecnológicas e biomédicas [BERGER et al., 1999].

Os fluidos magnéticos ou ferrofluidos, também chamados de líquidos magnéticos, são suspensões coloidais de pequenas partículas de um material magnético de aspecto de coloração negra, com dimensões da ordem de nanômetros ( 10 nm) [WANG e HUANG, 2006].

Fluidos magnéticos de magnetita $\left(\mathrm{Fe}_{3} \mathrm{O}_{4}\right)$ podem ser preparados a partir de sais de $\mathrm{Fe}(\mathrm{II})$ e $\mathrm{Fe}$ (III) em solução básica. As partículas devem ser superparamagnéticas, ou seja, ter tamanhos menores que $30 \mathrm{~nm}$, alto valor de magnetização de saturação e se manter separadas umas das outras quando suspensas em um meio líquido. Essa separação é conseguida por meio de uso de surfatantes impedindo que as nanopartículas se aglomerem [HONG et al., 2007; LIU et al., 2007].

Uma vez preparados, têm a característica de se atraírem fortemente ao serem submetidos a um campo magnético externo, forçando o líquido a manter uma direção, permitindo 0 controle de sua movimentação. A sua desmagnetização ocorre no momento em que esse campo é removido, caracterizando o comportamento típico de um material superparamagnético [ORTEGA et al., 2010]. 
As pesquisas com materiais com propriedade superparamagética têm avançado e atraído a atenção, principalmente para aplicações na área da saúde. No entanto, para que as partículas magnéticas sejam utilizadas com essa finalidade, há a necessidade de sua conjugação com outros materiais, formando um híbrido com característica biocompatível, permitindo a sua interação com as células do corpo, no momento do seu contato com meio biológico, minimizando os efeitos causados pelas possíveis reações de defesa do sistema imunológico [MEYER et al., 2009; ZHU et al., 2008].

Por outro lado, esse conjugado pode criar condições favoráveis à imobilização de biomoléculas, tais como os anticorpos e enzimas, em sua estrutura criando modelos para a realização de ensaios in vitro [MEYER et al., 2009; ZHU et al., 2008].

\section{III.3. Compósito}

O surgimento dos materiais compósitos foi motivado pela crescente necessidade de se combinar propriedades consideradas incompatíveis de diferentes materiais, originando um material único, que além de exibir características novas e desejáveis, também apresentasse propriedades resultantes superiores as dos materiais separados.

Buscou-se então reunir em um único material, um ou mais atributos, tal como, rigidez adequada, resistência mecânica, densidade, resistência à corrosão, melhoria de propriedades térmicas, tenacidade, resistência à fadiga $e$ funcionalidade, de tal maneira que se obtivesse um material conjugado capaz de desempenhar novas funções, apresentando-se como possível solução para muitos problemas de base tecnológica [JOSÉ e PRADO, 2005].

Para ser designado um compósito, é preciso que o material reúna duas fases primordiais, uma contínua (matriz) e uma dispersa (reforço ou modificador), cujas propriedades são obtidas a partir da combinação das propriedades dos constituintes individuais (regra da mistura) [FOWLER et al., 2006].

A matriz é responsável pela distribuição e transferência das tensões para a carga; ligação entre as mesmas; e proteção da superfície das cargas. Além do mais, confere estrutura ao material compósito, preenchendo os espaços vazios que ficam entre a fase dispersa, mantendo-os em suas posições relativas [CAMPBELL, 2010; FOWLER et al., 2006]. 
À fase dispersa cabe realçar as propriedades mecânicas, eletromagnéticas ou químicas do material compósito como um todo. Pode ainda surgir uma sinergia entre o material de matriz e o material de reforço, resultando o material compósito final com propriedades não existentes nos materiais originais [CAMPBELL, 2010; FOWLER et al., 2006].

Sendo assim, os materiais compósitos, também conhecidos como conjugados ou compostos, são formados por diferentes componentes, que, quando analisados macroscopicamente, devem apresentar-se homogêneos [CAMPBELL, 2010; FOWLER et al., 2006].

\section{3.1. Biocompósitos}

Biocompósitos são materiais compostos, no qual pelo menos uma das fases seja biomaterial, que além de exibir as características descritas para o compósito, se comportem como um material biocompatível, e não cause reações adversas, tóxicas ou carcinogênicas quando mantida em contato com o meio biológico. Biomateriais podem substituir tecidos vivos, de forma apropriada e devem apresentar propriedades físicas e biológicas compatíveis com os tecidos hospedeiros, de modo a estimular uma resposta adequada dos mesmos. Tais propriedades caracterizam a biocompatibilidade [KAWACHI et al., 2000].

Eles são usados com fins diagnósticos ou terapêuticos, entrando em contato com os tecidos e/ou fluidos biológicos de forma definitiva ou provisória durante um período de tempo suficientemente longo, sem estimular reações imunológicas ou alérgicas. Também podem ser aplicados em imunoensaios servindo como suporte para a ligação de biomoléculas. Desta interação entre os diferentes componentes espera-se que o seu objetivo final seja atingido, a utilização em biosistemas [FOWLER et al., 2006].

Os biocompósitos têm uma variedade de aplicações:

- como prótese: substituindo partes do corpo ou órgãos;

- em diagnósticos: ajudando na detecção de anomalias;

- em procedimentos terapêuticos: no tratamento, cicatrização;

-como armazenamento de substâncias: sistema de liberação controlada de fármacos;

- como suporte: para a imobilização de enzimas [CAMPBELL, 2010; FOWLER et al., 2006]. 


\section{III.3.2. Nanocompósitos}

Nanocompósitos geralmente se referem a materiais compósitos em que pelo menos uma fase (a fase de enchimento) possui dimensões da ordem de alguns nanômetros. Tal como acontece nos compósitos tradicionais, um dos componentes serve de matriz, na qual partículas do segundo material se encontram dispersas [LEE et al., 2005.].

\section{III.3.3. Biocompósito magnético}

As nanopartículas magnéticas possuem citotoxicidade, sendo necessário o desenvolvimento de técnicas de encapsulação com a finalidade de atribuí-las as propriedades biocompatíveis [CASTRO et al., 2010; HONG et al., 2009], formando um nanobiocompósito com vasta aplicação na medicina e na biomedicina, tais como: terapia celular em células de rotulagem, separação e purificação, imobilização de proteínas, contrastando realce na ressonância magnética $(\mathrm{RM})$, hipertermia terapêutica localizada e biossensores.

Geralmente os biomateriais poliméricos, como por exemplo, a quitina e a quitosana, são extensamente empregadas com esse fins [RINAUDO, 2006].

\section{III.4. Quitina}

A quitina é um biopolímero que atua como componente estrutural em plantas e animais. Foi identificada em 1811 por Henri Braconnot, antes mesmo do isolamento da celulose, mas, devido ao conhecimento limitado de suas propriedades principais, as suas aplicações industriais só foram intensificadas na década de 1970. A princípio, Braconnot deu-lhe o nome de fungina. O nome quitina foi dado por Odier, em 1823, quando esta foi isolada de insetos. Somente em 1843, Lassaigne descobriu a presença de nitrogênio em sua estrutura [KHOUSHAB e YAMABHAI, 2010].

Esse polissacarídeo ocorre na natureza como microfibrilas cristalinas ordenadas, tendo uma função análoga a do colágeno nos animais superiores, e da celulose nas plantas terrestres, formando componentes estruturais no exoesqueleto dos artrópodes, ou nas paredes celulares de fungos e leveduras, conferindo-lhes rigidez, e garantindo a integridade estrutural aos animais e proteção às plantas [CAMPANA-FILHO et al., 2007]. 
Estruturalmente a quitina pode ser comparada à celulose. A diferença entre elas é observada na posição do carbono 2, onde há a substituição do grupo $\mathrm{OH}$, presente na celulose, pelas unidades repetitivas 2-acetamido-2-desoxi-Dglicose e 2-amino-2-desoxi-D-glicopiranose, interligadas por ligações glicosídicas $\beta-(1 \rightarrow 4)$, na cadeia da quitina (FIG. 4) [BATTISTI e CAMPANA-FILHO, 2008].

Observa-se que a cadeia da quitina não é composta totalmente por grupos acetamido. Essa alteração estrutural pode ocorrer durante o processo de extração, ocasionada por meio de reações de desacetilação, nas quais alguns grupos acetamido são substituídos por cerca de 5 a 10\% de unidades 2-amino-2desoxi-D-glicopiranose. E esse grau de $N$-acetilação, ou seja, a proporção de 2acetamido-2-desoxi-D-glicopiranose para 2-amino-2-desoxi-D-glicopiranose nas unidades estruturais tem um efeito notável sobre as propriedades do polímero, tornando-o insolúvel na maioria dos solventes (FIG. 4) [BATTISTI e CAMPANAFILHO, 2008; CAMPANA FILHO et al., 2007].

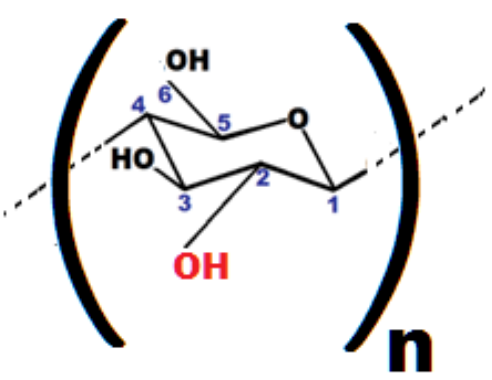

Celulose

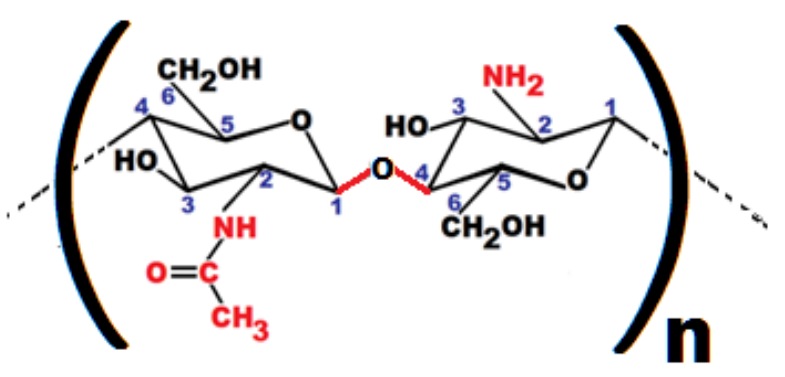

Quitina

Figura 4 - Estrutura das unidades repetitivas sacarídeas da celulose (glicose), e díssacarídeas da quitina (glicopiranose), unidas pelas ligações glicosídicas $\beta-(1 \rightarrow 4) ; n$ se refere ao grau de polimerização.

Fonte: adaptação da referência AZEVEDO et al., 2007.

As fibras de quitina se distinguem de outros polímeros em muitos aspectos, são biocompatíveis, biodegradáveis, apresentam baixa toxicidade e baixa imunogenicidade. Estas propriedades, em combinação com boas propriedades mecânicas, tornam-nas uma boa candidata para procedimentos em sutura e implantes no corpo humano. Há relatos de que suturas de quitina foram 
absorvidas em cerca de 4 meses em músculos de ratos [KHOUSHAB e YAMABHAI, 2010; PILLAI et al., 2009; BENICEWICZ e HOPPER, 1991].

A aplicação em pacientes produziu resultados satisfatórios em termos de reação tecidual, com biocompatibilidade satisfatória. Testes de toxicidade, incluindo a toxicidade aguda, pirogenicidade e mutagenicidade deram resultados negativos em todos os aspectos. A persistência da resistência à tração da quitina foi boa nos materiais testados após o contato com a urina, a bile e o suco pancreático, porém, percebeu-se um enfraquecimento na presença de suco gástrico [NAKAJIMA et al., 1986].

Como se observa, a quitina já tem suas aplicações, porém, por ser um polímero de difícil dissolução em solventes orgânicos, houve a necessidade de se intensificar os estudos numa forma alternativa, que permitisse vislumbrar novos horizontes que ampliasse esse mercado. A solução encontrada foi a retirada dos grupos acetil de sua cadeia principal por meio de reações químicas, promovendo a sua desacetilação e dando origem a quitosana [KHOUSHAB e YAMABHAI, 2010; PILLA et al., 2009; DUTTA, et al., 2004; GOY, et al., 2009].

\section{III.5. Quitosana}

A quitosana é um aminopolissacarídeo biodegradável, hidrofílico, não tóxico e biocompatível, obtido, principalmente, a partir da desacetilação alcalina da quitina, embora possa ocorrer naturalmente em pequenas quantidades a partir de certos microrganismos como fungos [NAIR e LAURENCIN, 2007; BADAWY e RABEA, 2011].

As fontes de matéria-prima e os métodos de fabricação influenciam diretamente suas propriedades, tais como, o grau de pureza, a viscosidade, o grau de desacetilação, o peso molecular e a estrutura polimérica (grupos amino, acetamido e hidroxila) [BADAWY e RABEA, 2011].

Embora a sua estrutura seja representada como um homopolímero, a operação de desacetilação raramente é completa. Assim como a quitina, a sua cadeia polimérica também é composta por unidades repetitivas (2-amino-2desoxi- D-glicopiranose e 2-acetamido-2-desoxi-D-glicose) interligadas por ligações glicosídicas $\beta-(1 \rightarrow 4)$. Porém, inversamente ao que ocorre com sua precursora, na quitosana há a predominância da 2-amino-2-desoxi-Dglicopiranose, mantendo um número considerável de grupos amino, fortemente reativos, em sua superfície, o que lhe confere novas propriedades, além daquelas 
descritas para a quitina (FIG. 5) [NAIR e LAURENCIN, 2007; BADAWY e RABEA, 2011].

Dessa feita, o grau de desacetilação (GD), uma das mais importantes propriedades químicas desse polímero, determina a quantidade de grupos amino $\left(\mathrm{NH}_{2}\right)$ na cadeia, sendo o material definido como quitosana, quando o grau de desacetilação atingir valores superiores a 75\% [SPIN-NETO et al., 2008.].

A determinação deste parâmetro implica na propriedade da quitosana em adsorver maior ou menor concentração de íons metálicos, porque o grupo amino disponível pode complexar alguns íons metálicos [JANEGITZ et al, 2007].

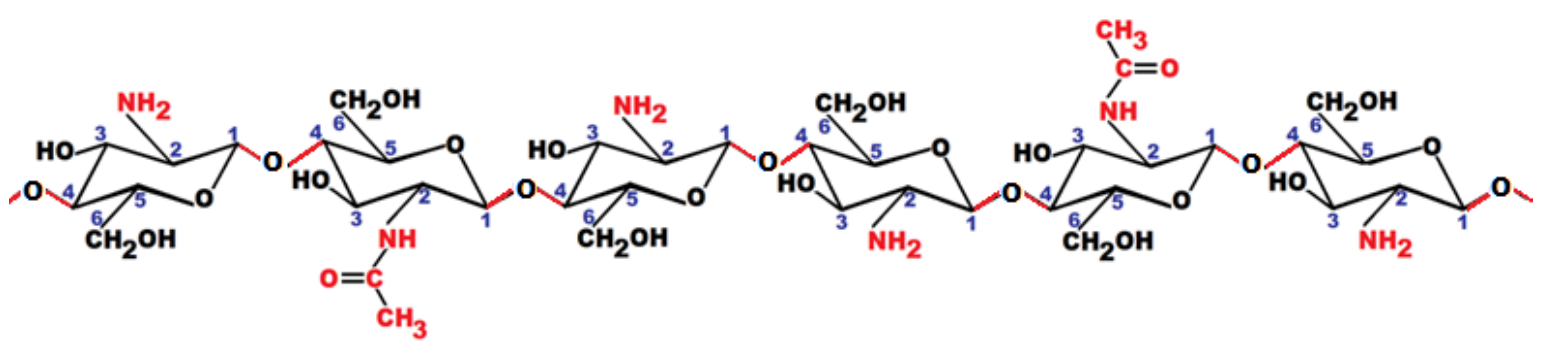

FIGURA 5 - Cadeia polimérica da quitosana.

A quitosana é insolúvel em água, álcalis, ácidos concentrados e solventes orgânicos, sendo solúvel em ácidos orgânicos quando o pH da solução for menor que 3. Os grupos amino $\left(-\mathrm{NH}_{2}\right)$ da quitosana ficam completamente protonados $\left(-\mathrm{NH}_{3}{ }^{+}\right)$em $\mathrm{pH}$ próximo de 3; dessa forma a cadeia polimérica se mantém carregada positivamente, ocasionando a sua dissolução [BATTISTI e CAMPANA-FILHO, 2008; CAMPANA-FILHO e SIGNINI, 2001, FÁVERE et al., 2010].

Por ser um biomaterial polimérico, é muito utilizado com propósito de recobrimento de nanopartículas magnéticas. As ligações químicas estabelecidas entre as duas partes são responsáveis por manter o sistema coeso, porém, a criação de ligações cruzadas (cross-linking) na matriz em processo de reticulação polimérica melhora as suas propriedades mecânicas, além de estabelecer sítios ativos em sua superfície [BHATTARAl et al., 2008].

O glutaraldeído (pentano-1,5-dial) é um reagente bifuncional constantemente utilizado no processo de reticulação, criando, ao mesmo tempo, sítios de ligação que permitem a imobilização de biomoléculas na superfície 
polimérica. A sua molécula consiste numa cadeia formada por três átomos de carbono, com um grupo carbonila extremamente reativo, ligado em cada uma das extremidades (FIG. 6).

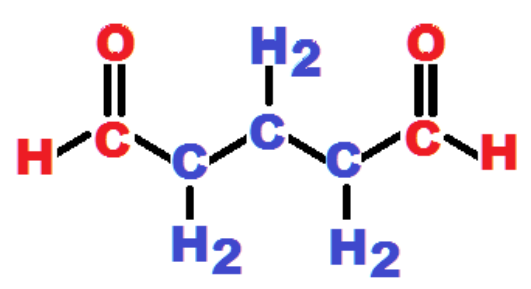

FIGURA 6- Fórmula molecular do glutaraldeído

A reação ocorre entre o grupo amino da quitosana e as duas extremidades do agente reticulante, havendo a formação de pontes ou ligações cruzadas (cross-linking) intermolecularmente, configurando-se o processo de reticulação, podendo melhorar a sua resistência mecânica, química e térmica. Por outro lado, essa reação ocorrerá simultaneamente entre os grupos amino do polímero bem como diretamente na cadeia deste com apenas uma das extremidades do glutaraldeído. Neste caso, cada extremidade do grupo aldeído livre na superfície polimérica é um grupo funcional ativo (FIG. 7) [D'AYALA et al., 2008]. 


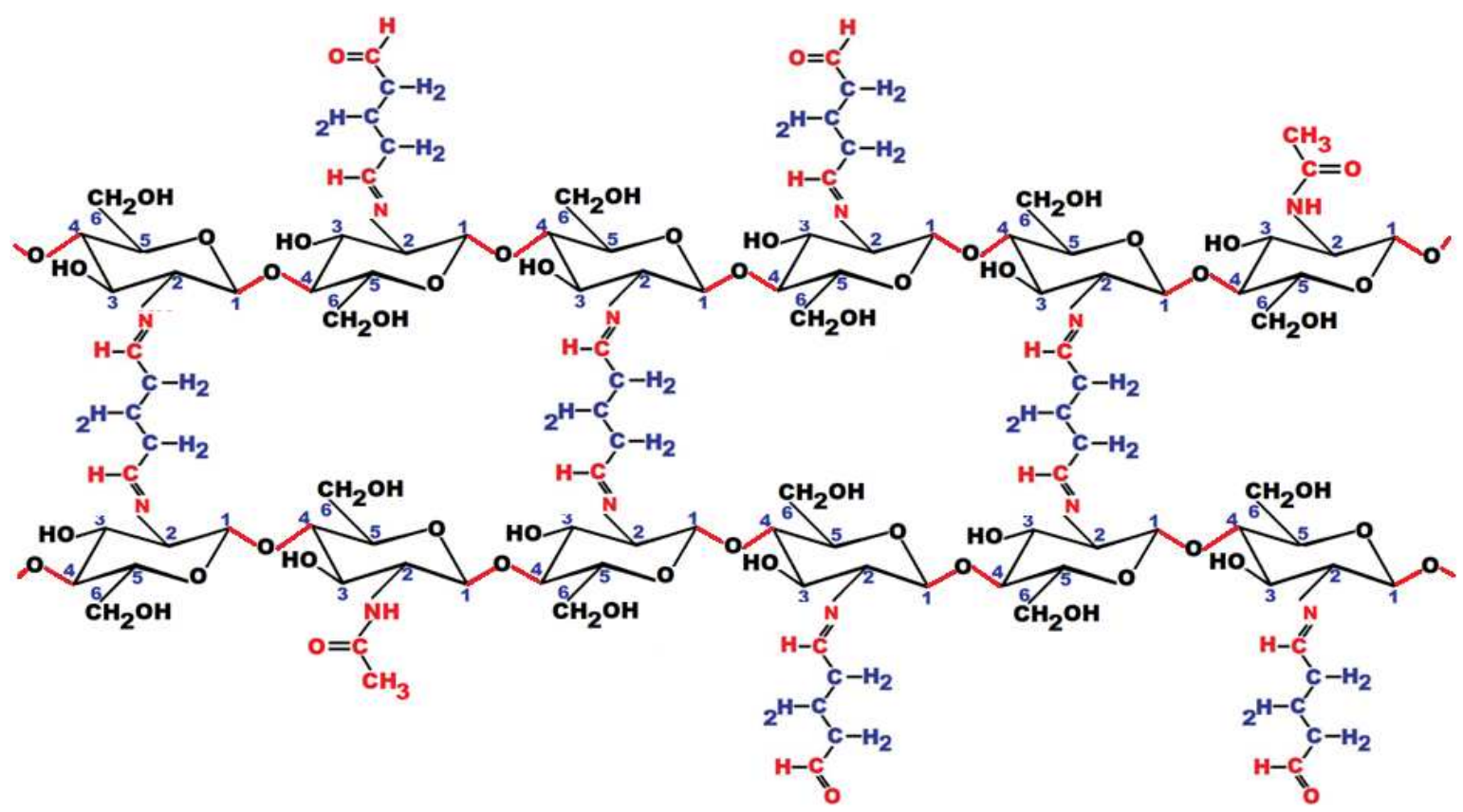

FIGURA 7 - Cadeia polimérica da quitosana reticulada pelo glutaraldeído.

\section{III.6. Proteínas}

As proteínas representam cerca de 50 a $80 \%$ do peso seco da célula, sendo o composto orgânico mais abundante da matéria viva. Elas são constituídas de aminoácidos, unidos por um tipo específico de ligação covalente, denominada ligação peptídica (FIG. 8). Os aminoácidos são moléculas orgânicas formadas por cadeias de carbono, ligadas a átomos de hidrogênio, oxigênio, nitrogênio e, às vezes, enxofre, contendo um grupo terminal carboxila $(\mathrm{COOH})$ e um grupo terminal amina $\left(\mathrm{NH}_{2}\right)$ [ALBERTS et al., 1999].

Existem na natureza 20 tipos de aminoácidos, diferenciando-se entre si por um grupamento denominado radical $(\mathrm{R})$ Os aminoácidos são classificados conforme suas propriedades químicas: há os que apresentam cadeia polar, outros com cadeia apolar e os que podem adquirir carga elétrica [ALBERTS et al., 1999]. 


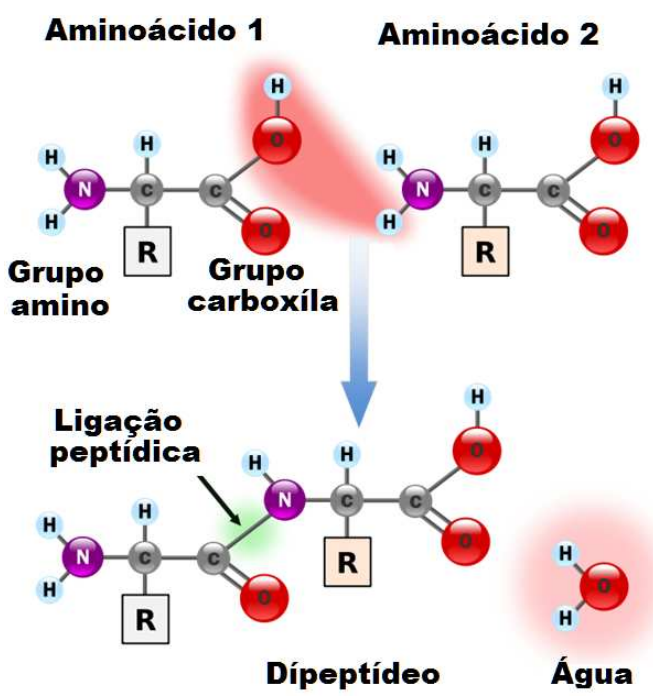

FIGURA 8 - Formação das proteínas por meio da ligação peptídica. Fonte: adaptação da referência ALBERTS et al., 2002.

As ligações peptídicas possibilitam a formação de milhares de estruturas proteicas, com diferentes tamanhos, formas, propriedades e funções, tais como de armazenamento, estruturais e catalíticas [ALBERTS et al., 1999].

\section{III.6.1. Proteínas de armazenamento}

Muitas proteínas são nutrientes na alimentação, como é o caso da albumina do ovo e a caseína do leite.

Algumas plantas armazenam proteínas nutrientes em suas sementes para a germinação e crescimento. Outras atuam no armazenamento de certos cofatores, como por exemplo, a ferritina, que armazena átomos de ferro [ALBERTS et al., 1999].

\section{III.6.2. Proteínas estruturais}

As proteínas estruturais participam da arquitetura celular, conferindo formas, suporte e resistência, participam da estrutura dos tecidos. Essas proteínas servem como filamentos de suporte, cabos ou lâminas para fornecer proteção ou resistência às estruturas biológicas [ALBERTS et al., 1999].

A mais importante para os tecidos animais é o colágeno: proteína de alta resistência, encontrada na pele, nas cartilagens, nos ossos e tendões. Outro exemplo é a queratina. Ela é uma proteína impermeabilizante encontrada na pele, 
no cabelo e nas unhas e evita a dessecação, o que contribui para a adaptação do animal à vida terrestre [LEHNINGER et al., 2000].

\section{III.6.3. Enzimas}

As enzimas são macromoléculas de natureza proteica, portanto, formadas por aminoácidos. É o grupo mais variado de proteínas. Praticamente todas as reações do organismo são catalisadas por enzimas.

As enzimas são catalisadores biológicos com elevada especificidade aos substratos, moléculas sob os quais atuam. Elas viabilizam as atividades celulares, quebrando moléculas, ou participando da formação de novos produtos [ALBERTS et al., 1999].

Os mecanismos enzimáticos podem ser divididos em mecanismos de substrato único e mecanismos de múltiplos substratos.

Os estudos cinéticos com enzimas que atuam em apenas um substrato, como a triosefosfato isomerase, visam a medir a afinidade com que esta se liga ao substrato e a velocidade com que o transforma em produto. Por outro lado, ao se estudar uma enzima que une vários substratos, como a dihidrofolato redutase, a cinética enzimática pode mostrar também a ordem pela qual se ligam os substratos e se liberam os produtos [ALBERTS et al., 1999].

Como todos os catalisadores, aceleram substancialmente uma reação por meio da diminuição da energia de ativação $\left(\Delta G^{\ddagger}\right)$. Mesmo participando ativamente, elas não alteram o balanço energético das reações nas quais intervêm, nem tampouco modificam o seu equilíbrio, o qual é atingido bem mais depressa do que nas reações correspondentes e não catalisadas [ALBERTS et al., 1999].

A International Union of Biochemistry and Molecular Biology (IUBMB) classificou as enzimas em seis grandes grupos (Classes), de acordo com o tipo de reação que catalisam. São eles:

Óxido-redutases (1). São todas as enzimas que catalisam reações de oxidação-redução (reações com transferência de elétrons). Essa classe é subdivida em várias subclasses como, por exemplo:

- Desidrogenases. Catalisam reações de óxido-redução removendo elétrons na forma de um íon hidreto de seus substratos. $O$ íon hidreto é um átomo de hidrogênio carregado negativamente e com dois elétrons (-H:); 
- Redutases. Catalisam reações de redução, ou seja, adicionam átomos de hidrogênio ao substrato.

- Oxigenases. Catalisam a adição do oxigênio molecular ao substrato.

Transferases (2). Catalisam a transferência de grupos entre duas moléculas. Por exemplo, as metiltransferases transferem um grupo metila. $O$ doador pode ser um cofator (coenzima) que carrega o grupo a ser transferido.

Hidrolases (3) Catalisam a reação de hidrólise de várias ligações covalentes, como é o caso das peptidades que catalisam a hidrólise de ligações peptídicas.

Liases (4). Catalisam a clivagem de ligações C-C, C-O, C-N, entre outras, através de hidrólise ou oxidação. Elas diferem das outras enzimas, pois tem dois substratos envolvidos em uma direção e apenas um na outra direção de reação. Nos nomes comuns, encontramos as descarboxilases, aldolases, desidratases, ou mesmo liases. As desidratases são aquelas que eliminam água na reação.

Isomerases (5) Catalisam a modificação de uma única molécula, sem participação de outra. Por exemplo, as racemases e as epimerases, catalisam a reação de racemização ou epimerização de centros quirais e as cis-transisomerases rearranjam a geometria de duplas ligações.

Ligases (6). Catalisam reações de síntese de uma nova molécula a partir da ligação entre duas moléculas, com a concomitante hidrólise de ATP ou outro composto trifosfatado. São conhecidas como ligases, carboxilases ou Sintetases, sendo que existem 6 subclasses dessas enzimas.

\section{III.6.4. Aplicações das enzimas}

No campo da pesquisa as enzimas participam de inúmeros processos químicos, como por exemplo, no desenvolvimento de novos biocombustíveis. Lipases de diversas fontes têm sido imobilizadas e usadas na produção de biodiesel, porém as mais utilizadas pela maioria dos pesquisadores foram obtidas de Candida antarctica e Thermomyces lanuginosus [DABDOUB e BRONZEL, 200].

Comercialmente, são utilizadas na fabricação de produtos industrializados, tais como, na produção de alimentos consumidos diariamente, entre os quais o pão, o vinho e o queijo. 
No entanto, muitas vezes, o seu emprego é inviabilizado, devido ao custo elevado, a sua rápida inativação em condições fisiológicas, e a alta sensibilidade à ação de proteases endógenas e inibidores naturais. Por esses motivos, o desenvolvimento de ferramentas que permitam torná-las reutilizáveis, mantendo a sua atividade catalítica por um período mais longo, é de grande interesse [DABDOUB e BRONZEL, 200].

Os pesquisadores têm empregado grandes esforços nesse sentido, e a imobilização enzimática é uma forma de superar essas limitações. Por definição, enzimas imobilizadas são aquelas fisicamente confinadas ou localizadas numa determinada região do espaço, com retenção de suas atividades catalíticas, e que possam ser reutilizadas repetida e continuamente. [LEE e HUANG, 2008].

As enzimas imobilizadas proporcionam algumas vantagens em relação às livres, tais como a possibilidade do aumento de sua estabilidade, boa recuperação da atividade enzimática nos diferentes ciclos de reação, longa meiavida operacional e facilidade de separação do meio de reação; o que acarreta economia significativa no custo global do processo, desde que o procedimento de imobilização não seja muito dispendioso. A recuperação e a reutilização da enzima em ciclos seguidos tornam o processo mais vantajoso economicamente [SPAHN, MINTEER, 2008].

\section{III.7. Métodos de imobilização}

Há uma variedade de métodos usados para imobilizar enzimas. Três dos mais comuns são de adsorção física ou química de uma enzima em um suporte, muitas vezes, uma matriz polimérica, encapsulação, e ligação covalente a um suporte (cross-linking). [SPAHN e MINTEER, 2008].

A escolha do melhor método para a imobilização enzimática para um determinado trabalho dependerá de vários fatores, tais como, solubilidade da enzima, estabilidade, condições ótima de ação ( $\mathrm{pH}$ e temperatura), tipo do substrato e aplicabilidade do produto final.

\section{III.7.1. Ligação cruzada}

Utilizam-se reagentes bifuncionais, por exemplo, o glutaraldeído, que reage com o grupo amino da quitosana formando ligações cruzadas, obtendo-se macromoléculas insolúveis em água [MONTEIRO Jr. e AIROLDI, 1999]. 


\section{III.7.2. Adsorção física em suportes insolúveis em água}

Esse é um método relativamente simples, em que as enzimas são mantidas presas à superfície dos substratos por meio de forças físicas, Van der Walls, ou outras forças adicionais, como interações hidrofóbicas, pontes de hidrogênio e ligações heteropolares [PANESAR et al., 2010].

As vantagens dessa técnica se referem a sua simplicidade de execução e pouca influência exercida na conformação da enzima, devido a não utilização de ligações não fisiológicas da enzima com reagentes químicos. Porém, a fragilidade dessas ligações exige mais cuidado na manutenção das condições ideais de temperatura, $\mathrm{pH}$, e força iônica, a fim de evitar a dessorção [PANESAR et al., 2010].

\section{III.7.3. Ligação iônica}

Diferente da adsorção física, as ligações iônicas são mais fortes. Ligações desse tipo baseiam-se na atração eletrostática entre grupos (suporte e/ou enzima) carregados de cargas elétricas. As proteínas possuem grupos amino e carboxilas e, dependendo do $\mathrm{pH}$ do meio, podem apresentar-se positivas ou negativamente carregadas. Dessa forma, as proteínas positivamente carregadas tendem a se aderir a suportes negativamente carregados. Para a manutenção da integridade desse sistema é necessário manter a estabilidade do $\mathrm{pH}$ e a força iônica correta, pois, o desequilíbrio de qualquer um desses parâmetros pode destruir e inviabilizar o sistema [BRENA e BATISTA-VIERA, 2010].

\section{III.7.4. Ligação covalente}

A imobilização de enzimas em suportes insolúveis é feita por meio de ligações covalentes de grupos funcionais não ativos da enzima, e grupos reativos (hidroxila, amino, fenólico) ligados à superfície do suporte (celulose, quitina, quitosana).

A desvantagem desse tipo de imobilização é que ela provoca um grande estresse na enzima. A imobilização brusca conduz normalmente a alterações consideráveis na conformação, resultando numa perda significativa da atividade catalítica. 
Por outro lado, esse método proporciona uma série de vantagens: menor susceptibilidade a problemas decorrentes de variações de $\mathrm{pH}$, força iônica, solvente e temperatura, além de ligação forte entre a enzima e o suporte; a fácil interação enzima/substrato devido à localização superficial do catalisador; aumento da estabilidade térmica em decorrência da forte interação com o suporte [PANESAR et al., 2010; SHELDON, 2007].

\section{III.7.5. Encapsulação}

As enzimas imobilizadas por encapsulação ficam aprisionadas, ou seja, posicionadas dentro da matriz polimérica ou membrana, sendo esse processo de mera retenção física [PANESAR et al., 2010; SHELDON, 2007].

\section{III.7.6. Combinação de métodos}

Em algumas situações, quando se deseja obter enzimas imobilizadas com maior atividade ou aumentar a resistência mecânica dos suportes, é recomendável a utilização de uma combinação de métodos para a imobilização de enzimas. Por exemplo, pode-se melhorar a estabilizade da enzima imobilizada por adsorção promovendo-se uma ligação cruzada entre as moléculas da enzima com o glutaraldeído.

\section{III.8. Ensaio enzimático}

Ensaios enzimáticos são procedimentos laboratoriais que tem enzima como catalisador e acompanham a transformaçao de um substrato em produto. Uma vez que as enzimas não são consumidas pelas reações que catalisam, nos ensaios, as mudanças na concentração do substrato ou do produto, permitem determinar a atividade enzimática, parâmetros de reação de velocidade, afinidade pelo substrato entre outros.

Há vários métodos de medida (ou acompanhamento da reação enzimática): os ensaios espectrofotométricos medem a mudança de absorção da luz entre produtos e reagentes; ensaios radiométricos envolvem a incorporação ou liberação de radioatividade para medir a quantidade de produto que surge ao longo do tempo.

Os ensaios espectrofotométricos são mais convenientes, pois permitem a medição contínua da velocidade de reação. Embora os ensaios radiométricos 
exijam a remoção e contagem de amostras (ou seja, são ensaios descontínuos), são habitualmente de grande sensibilidade e podem medir vários níveis da atividade enzimática [LEHNINGER et al., 2000].

\section{III.8.1. Cinética enzimática}

A cinética enzimática estuda as reações químicas catalisadas pelas enzimas, enfocando as velocidades das transformações que se processam sob os efeitos das condições de trabalho, como pH, temperatura, concentração de reagentes e enzimas.

Em uma reação catalítica enzimática, uma enzima liga-se à molécula de seu substrato (S) para formar o complexo enzima-substrato (ES), em um passo reversível relativamente rápido como mostra a equação 1. Esta idéia foi expandida em uma teoria geral da ação das enzimas, especialmente por Leonor Michaelis e Maud Leonora Menten, em 1913 [LEHNINGER et al., 2000].

\section{$E+S \leftrightarrows E S$}

A seguir, em um passo mais lento há a limitação da velocidade da transformação global do reagente em produto, o complexo (ES) se rompe com o reaparecimento da enzima livre e a formação do produto da reação $(P)$, equação 2. Existe de forma transiente um complexo (EP), havendo então dissociação deste complexo em enzima livre $(E)$ e produto $(P)$.

\section{$E S \Longleftrightarrow E P \leftrightharpoons E+P$}

Em qualquer instante de uma reação, a enzima existe nas duas formas, a não ligada ao substrato, ou a forma livre (E), e a forma ligada (ES). Um dos fatores que afetam a velocidade de uma reação catalisada por uma enzima é a concentração do substrato $[S]$. O estudo do efeito da concentração de substrato é complicado pelo fato de $[S]$ variar durante o curso de uma reação à medida que o substrato é convertido em produto. Uma forma de simplificar o estudo é medir a velocidade inicial da reação $\left(V_{0}\right)$. Em um experimento cinético a $[S]$ é sempre muito maior que a concentração da enzima $[E]$, e se o tempo de reação é 
suficientemente curto, as mudanças da $[S]$ serão desprezíveis, podendo ser considerada como uma constante.

O efeito provocado em $V_{0}$ pela variação da $[S]$ quando a concentração de enzima é mantida constante está mostrado na FIG. 9 [LEHNINGER et al., 2000].

Em concentrações pequenas do substrato $(S)$, a maior quantidade da enzima estará na forma livre (E). Nestas condições, a velocidade de reação será proporcional à $[S]$ porque o equilíbrio da equação 1 , à medida que a $[S]$ aumentar, será deslocado na direção da formação de mais ES. Em concentrações maiores de substrato, $\left(V_{0}\right)$ aumenta por incrementos menores em respostas aos aumentos da $[S]$. Finalmente, é alcançado um ponto acima do qual ocorrem apenas aumentos insignificantes em $\left(V_{0}\right)$, mesmo com aumentos em [S], sendo este ponto chamado de velocidade máxima $\left(V_{\text {máx }}\right)$. A $V_{\text {máx }}$ será atingida quando praticamente todas as moléculas da enzima estiverem na forma do complexo (ES), e a concentração da enzima livre (E) for insignificante. Neste caso, diz-se que a enzima está "saturada" com o substrato e a velocidade da reação não aumenta mais com os aumentos de $[S]$.

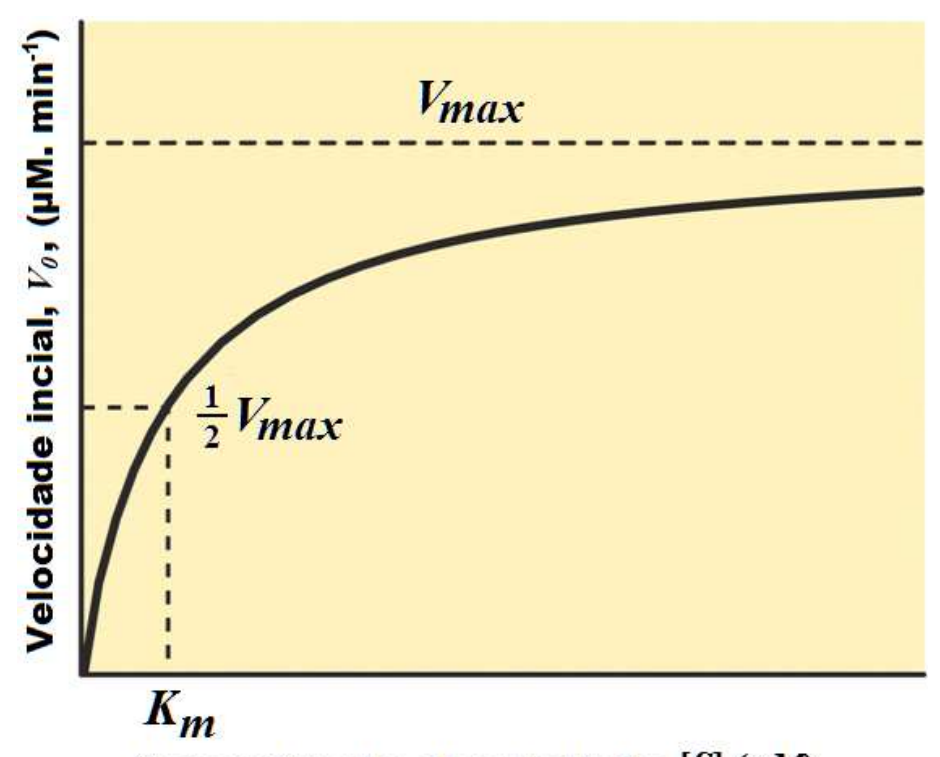

Concentração do substrato, $[S](n M)$

FIGURA 9 - Efeito da concentração de substrato na velocidade inicial de uma reação catalisada por enzima (concentração constante).

Fonte: LEHNINGER et al., 2000 


\section{III.8.2. Cinética de Michaelis-Menten}

A maioria das reações enzimáticas exibe a dependência semihiperbólica de $V_{0}$ em relação a $[S]$ representada pela curva da FIG. 9. A equação de Michaelis-Menten descreve matematicamente a relação semi-hiberbólica partindo de hipótese básica de que, nas reações enzimáticas, o passo limitante da velocidade é a quebra do complexo ES para formar o produto e a enzima livre. É a equação da velocidade (equação 3 ) de uma reação catalisada enzimaticamente e com um único substrato [LEHNINGER et al., 2000].

$$
V_{0}=\frac{V_{\max }[S]}{K_{m}+[S]}
$$

Onde [S], $V_{0}$ e $V_{\max }$ são as grandezas anteriormente definidas e $K_{m}$ a constante de Michaelis-Menten.

A constante de Michaelis-Menten é uma constante dinâmica, ou de pseudoequilíbrio, que expressa a relação entre as concentrações reais no estado estacionário ao invés de concentrações no equilíbrio.

$K_{m}$ é definida como a $[S]$ na qual $V_{o}$ é igual à metade de $V_{m a ́ x}$, e indica a "afinidade" de uma enzima pelo seu substrato. Quanto menor for o valor de $K_{m}$ maior será a afinidade da enzima pelo substrato [LEHNINGER et al., 2000].

\section{III.8.3. Gráfico de Lineweaver-Burke ou duplo recíproco}

Embora o gráfico obtido diretamente da equação de Michaelis-Menten seja de interpretação relativamente simples, existem tratamentos matemáticos que simplificam a representação gráfica da equação e permitem a obtenção rápida de parâmetros cinéticos [LEHNINGER et al., 2000].

A chegada dos computadores e programas que permitem ajustar regressões não lineares de forma simples, facilitou estas análises. No entanto, ainda é muito usual estimar os valores de $K_{m}$ e $V_{\max }$ nos gráficos lineares, do tipo $y=a x+b$, como os métodos de linearização de Lineweaver-Burke, o diagrama de 
Eadie-Hofstee e o gráfico de Hanes-Woolf aplicados à equação de MichaelisMenten [LEHNINGER et al., 2000].

O tratamento mais conhecido e o mais utilizado é o de LineweaverBurk (equação 4) cuja representação gráfica 1/v contra 1/[S] está ilustrada na FIG. 10. Este gráfico é também chamado duplo recíproco, pois, trata-se de uma representação gráfica do recíproco de ambos os parâmetros $V_{o}$ e $[S]$. A linha reta tem a inclinação igual a $K_{m} / V_{\text {máx }}$ o intercepto no eixo $1 / V_{o}$ igual a $1 /$ máx e 0 intercepto no eixo 1/[S] igual a $-1 / K_{m}$ [LEHNINGER et al., 2000].

$$
\frac{1}{V_{0}}=\frac{K_{m}}{V_{\max }[S]}+\frac{1}{V_{\max }[S]}
$$

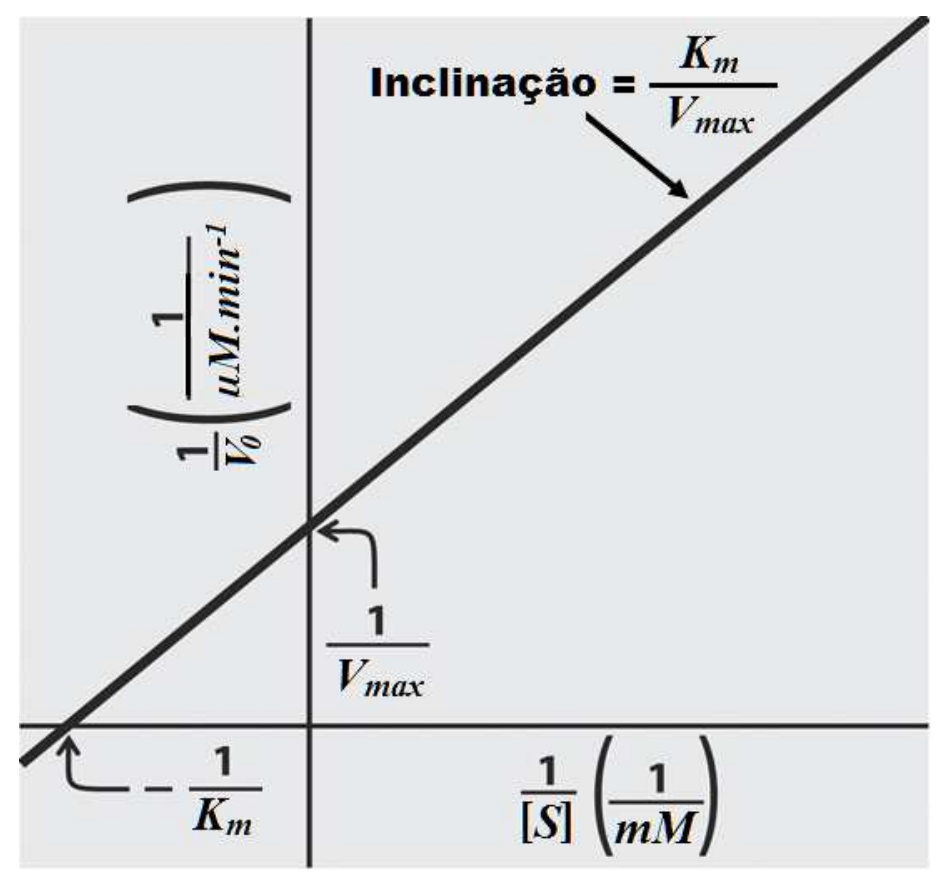

FIGURA 10 - Gráfico de Lineweaver-Burk ou duplo-recíproco. Fonte: LEHNINGER et al., 2000

Geralmente, os gráficos de Lineweaver-Burke distorcem as medidas realizadas a baixas concentrações de substrato $e$ isto pode dar lugar a estimativas não muito exatas de $V_{\max }$ e de $K_{m}$ [LEHNINGER et al., 2000]. 


\section{III.9. Proteínas para a imobilização}

Para o recobrimento das partículas magnéticas com 0 material biológico há a interferência direta das propriedades físico-químicas das superfícies envolvidas na ligação; neste sentido, para este trabalho foram escolhidas três proteínas comuns nos seres vivos, disponíveis comercialmente e com características estruturais distintas (TAB. 2), são elas a albumina de soro bovino, o colágeno e a tripsina.

O ponto isoelétrico de cada proteína é a resultante do número de aminoácidos carregados presentes em sua estrutura - ácido aspártico e glutâmico com cargas negativas e arginina, lisina e histidina com cargas positivas [LEHNINGER et al., 2000].

Outro parâmetro importante é o Índice alifático que é a resultante do número de aminoácidos alifáticos (glicina, alanina, prolina, valina, leucina, isoleucina e metionina) presentes na estrutura da proteína. Dentre as proteínas escolhidas para este estudo, o colágeno possui o menor índice [LEHNINGER et al., 2000].

TABELA 2 - Propriedades das proteínas albumina de soro bovino (BSA), colágeno e tripsina.

\begin{tabular}{cccc}
\hline PROPRIEDADES & BSA & Colágeno & Tripsina Porcina \\
\hline Peso molecular (kDa) & 66,433 & 51,182 & 23,476 \\
Estrutura & globular & Fibrosa & Globular \\
Ponto isoelétrico (pl) & 5,60 & 9,69 & 8,26 \\
Aminoácidos negativos & 99 & 41 & 11 \\
Aminoácidos positivos & 82 & 50 & 14 \\
Índice alifático & 76,14 & 28,64 & 83,50 \\
\hline
\end{tabular}

Fonte: The Protein Model Portal, 2010 


\section{III.9.1. Albumina de soro bovino (BSA)}

A proteína albumina de soro bovino (BSA) é uma proteína de caráter

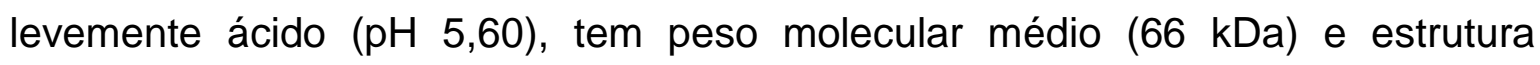
globular (FIG. 11) [The Protein Model Portal, 2010].

A BSA tem alta afinidade por ácidos graxos, hematina, bilirrubina e por pequenos compostos aromáticos negativamente carregados. A BSA é a principal carreadora de ácidos graxos, os quais são insolúveis no plasma sanguíneo. Ela forma ligações com fosfato de piroxidal, cisteína, e vários metais como $\mathrm{Cu}(\mathrm{II})$, $\mathrm{Ni}(\mathrm{II}), \mathrm{Hg}(\mathrm{II})$ e $\mathrm{Au}(\mathrm{I})$. Como uma proteína de transporte multifuncional, a albumina é o carreador chave ou reservatório de óxido nítrico em vários processos fisiológicos importantes, incluindo neurotransmissão. Ela também realiza muitas outras funções como eliminação de radicais livres de oxigênio e desativação de vários metabólitos lipofílicos tóxicos, como bilirrubina [QUIMING, 2005].

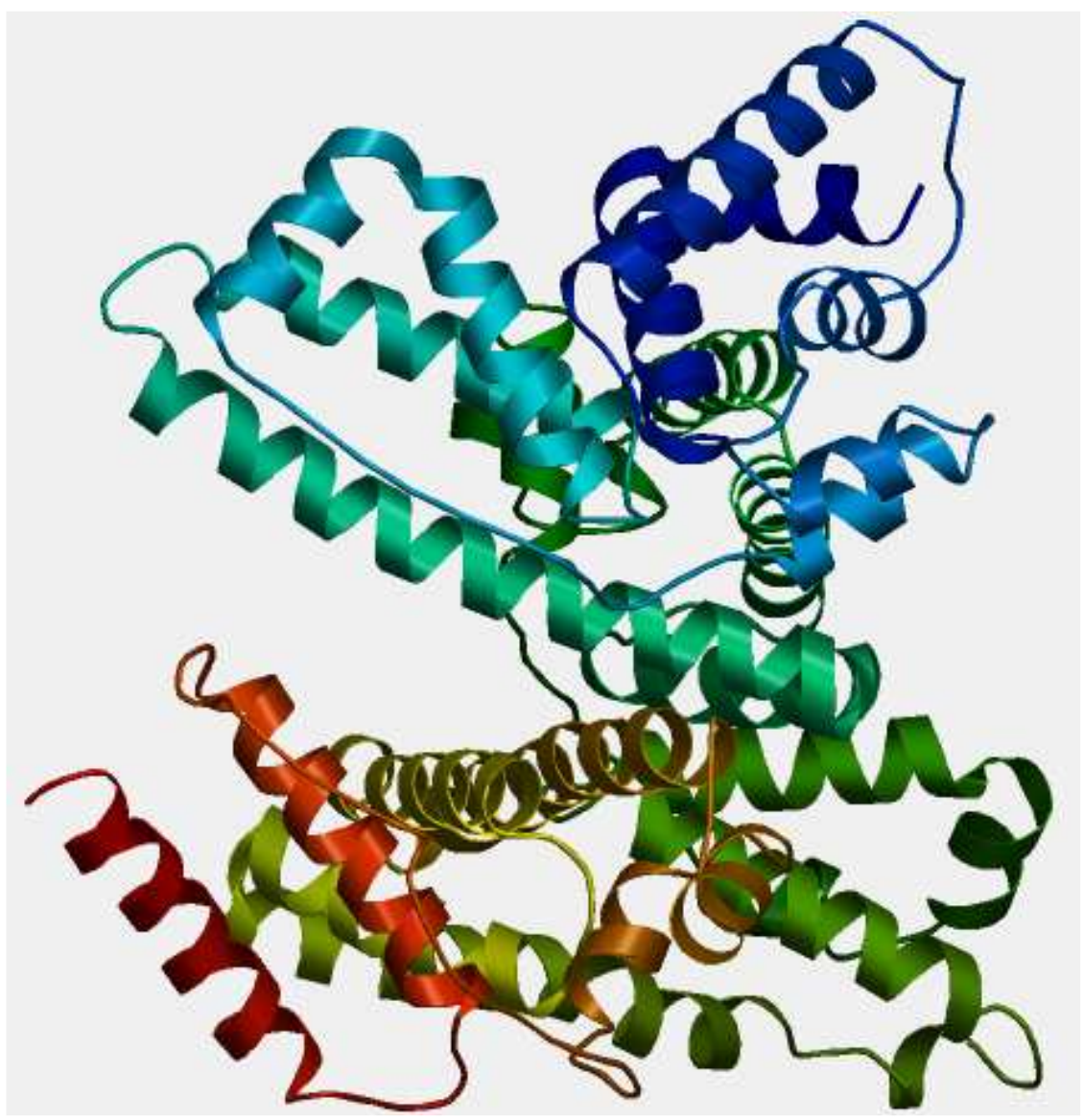

FIGURA 11 - Albumina de soro bovino Fonte: The Protein Model Portal, 2010 


\section{III.9.2. Colágeno}

O colágeno é uma proteína fibrosa com peso molecular de $51 \mathrm{kDa}$ (FIG. 12); é uma proteína básica, com ponto isoelétrico 9,69 e baixo índice alifático.

É sintetizado intracelularmente em pequenos segmentos e exportado para fora da célula, onde é processado por atuação de enzimas polimerizantes, até adquirir a estrutura própria de colágeno, em tripla-hélice. Cada uma das três cadeias proteicas é formada quase inteiramente por glicina (que representa 1/3 da sequência), prolina e lisina, como por mais dois aminoácidos que são modificados após síntese nos ribossomos: a hidroxiprolina e a hidroxilisina [ALBERTS et al., 1999; LEHNINGER et al., 2000]. 


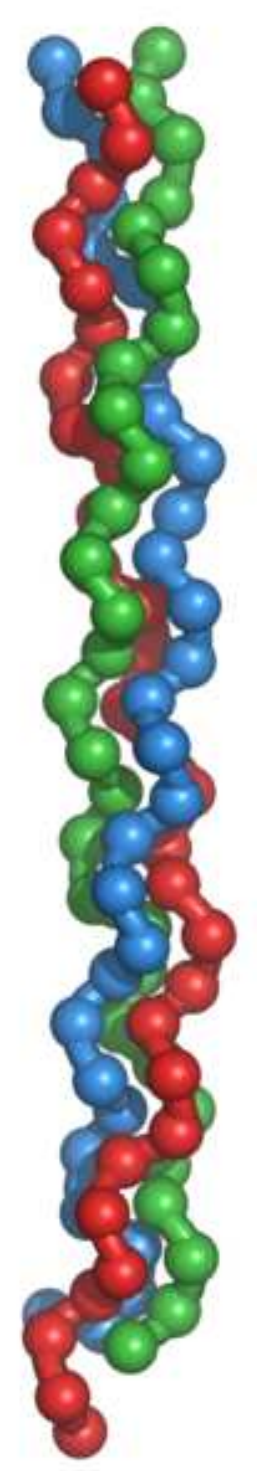

FIGURA 12 - Estrutura fibrosa do colágeno Fonte: LEHNINGER et al., 2000

No corpo humano, o colágeno desempenha várias funções, sendo a mais importante a estrutural (unir e fortalecer os tecidos).

Com o passar do tempo, o corpo pode sofrer algumas privações desta proteína decorrente principalmente da alimentação atual, muitas vezes carente de vitaminas e proteínas.

Durante os primeiros anos até a puberdade, essas deficiências não são visíveis e nem mostram suas evidências. A falta de colágeno vai se tornar mais visível e notável quando o homem entra na fase da maturidade, fase em que há uma possibilidade maior dele sofrer fraturas com freqüência. Também é nessa 
etapa da vida que começam a aparecer as rugas, pois a pele não tem mais a mesma elasticidade de antes [ALBERTS et al., 1999].

Todos os mamíferos fabricam o colágeno e seu uso se estende em diversas áreas de aplicação. No setor alimentício, ele é usado na fabricação de iogurtes, embutidos (salsichas, presunto, rosbife) e para sobremesas de fácil preparação (gelatinas, pudins, maria-mole), sendo também muito utilizado na área de cosméticos e produtos farmacêuticos [ALBERTS et al., 1999].

\section{III.9.3. Tripsina}

A terceira proteína escolhida foi a tripsina; de estrutura globular, com o menor peso molecular $(23,5 \mathrm{kDa})$, pl intermediário (pl 8,26) e o maior índice alifático entre as três proteínas estudadas (TAB. 2).

As células endócrinas do pâncreas produzem os zimogênios (formas inativas destas enzimas) tripsinogênio e quimotripsinogênio, os quais são secretados para o lúmen intestinal onde são ativados [Expasy proteomics Server, 2010].

A família da tripsina e quimotripsina é amplamente difundida na natureza e possui diversas funções na região intestinal. São enzimas hidrolases, proteolíticas pertencentes ao grupo das serino-proteases. Atuam na degradação de proteínas, clivando de forma específica a ligação entre os aminoácidos arginina e lisina na extremidade carboxila; além disso participam da lise celular de organismos invasores entre outros processos fisiológicos [Expasy proteomics Server, 2010; LEHNINGER et al., 2000].

A quimotripsina é uma protease, uma enzima digestiva que catalisa a hidrólise de ligações peptídicas. Ela é específica para quebrar ligações adjacentes à resíduos de aminoácidos aromáticos, sendo formada por três cadeias de polipeptídios ligados entre si por ligações de dissulfeto. A quimotripsina cliva ligações entre aminoácidos desde que a extremidade $C$ do polipeptídeo seja um aminoácido aromático (triptofano, fenilalanina e tirosina) [LEHNINGER et al., 2004].

Assim como todas as enzimas, possui um centro ativo, que é uma região onde os substratos e os grupamentos prostéticos se ligam. Os centros ativos contêm os radicais aminoácidos, chamados de grupamentos catalíticos, os 
quais participam diretamente da geração e quebra de ligações [LEHNINGER et al., 2004] (FIG. 13) .

A enzima e o substrato devem ter formas complementares de ligação, uma vez que as interações reversíveis de biomoléculas são feitas por ligações eletrostáticas, pontes de hidrogênio, forças de van der Waals e interações hidrofóbicas.

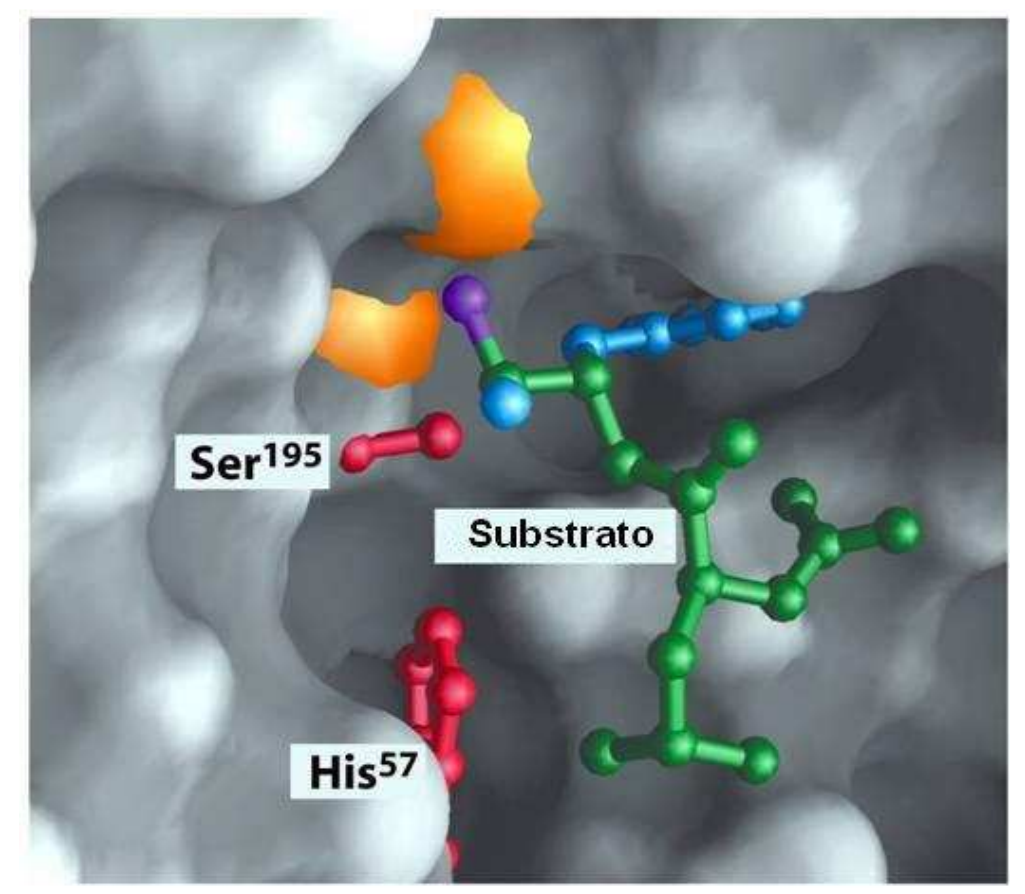

FIGURA 13 - Sítio ativo da quimotripsina formando um complexo com um substrato

Fonte: adaptação da referência LEHNINGER, 2004.

Essa protease aumenta a velocidade de hidrólise da ligação peptídica em um fator de pelo menos $10^{9}$. Porém, ela não catalisa o ataque direto da água sobre a ligação peptídica. Em contrapartida, ocorre a formação de um intermediário covalente transiente, a acil-enzima. Sendo assim, essa reação possui duas fases principais [LEHNINGER et al., 2004]:

Fase da acilação: a ligação peptídica é quebrada e uma ligação éster é formada entre o carbono da carbonila e a enzima.

Fase da desacilação: a ligação éster é hidrolisada e a enzima nãoacilada é regenerada. 
Na fase de acilação o nucleófilo é o oxigênio da $\operatorname{Ser}^{195}$. Geralmente a hidroxila da serina está protonada em $\mathrm{pH}$ neutro, mas a Ser ${ }^{195}$ está ligada por ligação de hidrogênio à $\mathrm{His}^{57}$, que, por sua vez, está ligada ao $\mathrm{Asp}^{102}$. Esses três aminoácidos são denominados tríade catalítica. Quando o oxigênio da Ser ${ }^{195}$ ataca o carbono da ligação peptídica, a Hist ${ }^{57}$, que está ligada por meio de pontes de hidrogênio, funciona como uma base geral, retirando o próton da serina, enquanto o $\mathrm{Asp}^{102}$, carregado negativamente, estabiliza a carga positiva que se forma no resíduo Hist ${ }^{57}$. Esse acontecimento previne a formação de uma carga positiva extremamente instável na hidroxila da Ser ${ }^{195}$, tornando-a muito mais nucleofílica. A Hist ${ }^{57}$ também pode atuar como um doador de prótons e protonar o grupo amino na porção substrato que foi deslocada. Um conjunto similar de transferência de prótons ocorre no passo da desacilação (FIG. 14) [LEHNINGER et al., 2004].

Enquanto ocorre o ataque ao grupo carbonila do substrato pela Ser ${ }^{195}$, há a formação de um intermediário de vida muito curta, no qual o oxigênio da carbonila incorpora uma carga negativa. Essa carga forma-se dentro de uma cavidade na enzima, denominada de fenda de oxiânion, e estabilizada por pontes de hidrogênio proporcionadas pelos nitrogênios dos grupos amida de duas ligações peptídicas do esqueleto da quimotripsina. Uma dessas pontes de hidrogênio ocorre apenas nesse intermediário e nos estados de transição de sua formação e quebra, diminuindo assim a energia necessária para atingir esses estados (FIG. 14) [LEHNINGER et al., 2004].

$\mathrm{Na}$ fase de desacilação ocorre essencialmente o oposto da fase de acilação, com o a reação no sentido inverso, onde há a formação do produto final e a regeneração da enzima livre. 


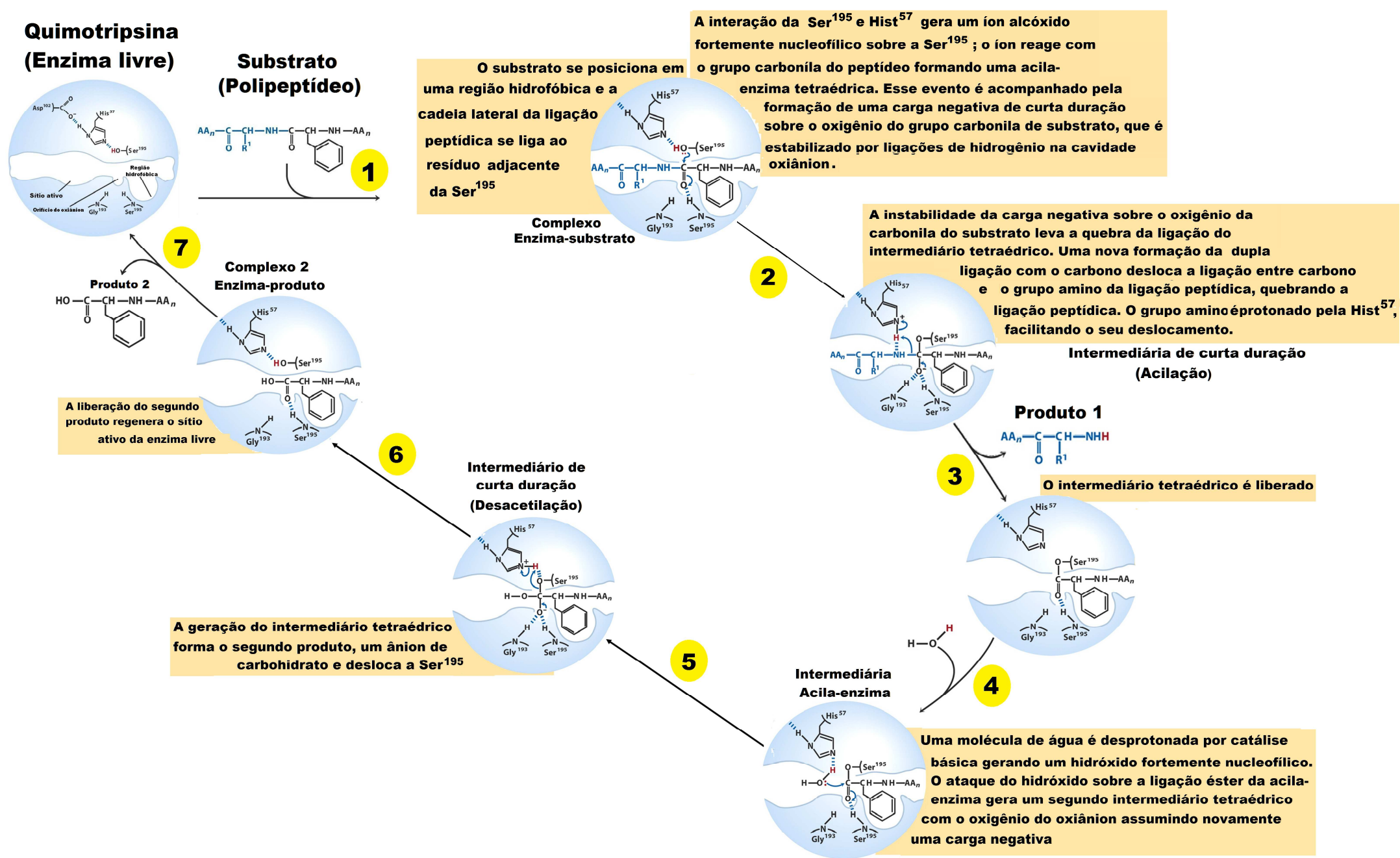

FIGURA 14 - Clivagem hidrolítica de uma ligação peptídica pela quimotripsina Fonte: adaptação da referência LEHNINGER et al., 2004. 
A tripsina é um bom modelo para imobilização de enzimas em nanopartículas magnéticas, pois é estável e pode-se determinar sua atividade em ensaios in vitro. Para tanto, foram desenvolvidos substratos sintéticos, como $\mathrm{N}-\alpha$ benzoil-DL-arginina-p-nitroanilida (BApNA), éster metílico de $p$-toluenossulfonil-Larginina (TAME) entre outros [HOSSEININAVEH et al., 2009].

O BApNA é um composto cromogênico que ao ser é hidrolisado pela tripsina, libera a p-nitroanilida como um produto cromogênico, originando compostos corados, os quais são utilizados na determinação da sua atividade, sendo detectável espectrofotometricamente a $410 \mathrm{~nm}$ (FIG. 15) [MARTEN et al., 2010]. Esse substrato apresenta um coeficiente de absorção molar de 7,68 $\times 10^{3}$ $\mathrm{AU} \mathrm{M}^{-1} \times \mathrm{cm}^{-1}$.

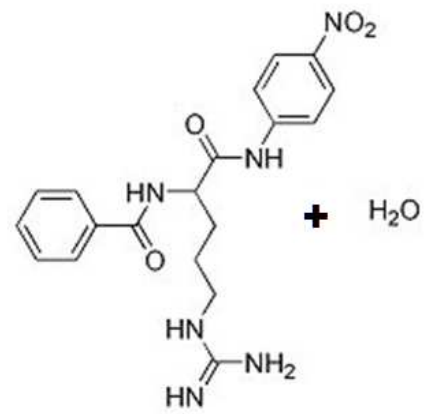

N- $\alpha$-Benzoil-DL-Arginina- $\rho$-Nitroanilida (BApNA)

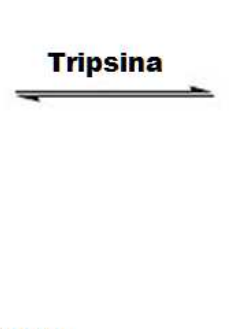

FIGURA 15 - Hidrólise do substrato cromogênico $N$-a-benzoil -DL-arginina- $p$ nitroanilida (BApNA) pela enzima tripsina.

Fonte: MARTEN et al., 2010. 


\section{MATERIAIS e MÉTODOS}

\section{IV.1. Reagentes e equipamentos}

\section{IV.1.1. Reagentes}

- Ácido acético, Merck

- Ácido Clorídrico (HCl), Merck

- Água destillada

- Água MilliQ

- Cloreto férrico hexahidratado $\left(\mathrm{FeCl}_{3} \cdot 6 \mathrm{H}_{2} \mathrm{O}\right)$, Merck

- Cloreto ferroso tetrahidratado $\left(\mathrm{FeCl}_{2} \cdot 4 \mathrm{H}_{2} \mathrm{O}\right)$, Merck

- Colágeno, Sigma-Aldrich

- Dimetilsulfóxido (DMSO)

- Glutaraldeído, Merck

- Hidróxido de sódio, Merck

- Quitosana em flocos, peso molecular médio, Sigma-Aldrich

- Reagente de Bradford, Coomassie Brilliant Blue G-250, Sigma-Aldrich

- Albumina de soro bovino (BSA), Sigma-Aldrich

- Substrato, BApNA (N-benzoil-DL-arginina-p-nitroanilida) , SigmaAldrich

- Tampão Tris-HCl 80 mM, pH 8,1, contendo $\mathrm{CaCl}_{2}$

- Tripsina de porco, Sigma-Aldrich 


\section{IV.1.2 Equipamentos}

- Banho termostático

- Célula calorimétrica, modelo DSC 822e, Mettler Toledo

- Cubetas semimicro de poliestireno, Sigma-Aldrich

- Difratômetro Rigaku modelo MultiFlex

- Dispersor extratur, modelo Q-252-K28, com uma haste de dispersão acoplada, Quimis

- Espectrofotômetro de UV-Vis, modelo Ultrospec III, Pharmacia LKB

- Imã

- Infravermelho por transformada de Fourier (FTIR), modelo 4700, Nicolet

- Magnetômetro de amostra vibrante (MAV), modelo 4500, EG\&G Princeton Applied Research

- Mesa agitadora, modelo Q225M, Quimis

- Microscópio eletrônico de varredura (MEV), modelo JEOL 200C

- Microtubos, Eppendorf

- Termobalança modelo TGA/SDTA 851, Mettler Toledo

- Vidraria 


\section{IV.2. Preparação das partículas de magnetita $\left(\mathrm{Fe}_{3} \mathrm{O}_{4}\right)$}

As partículas de magnetita $\left(\mathrm{Fe}_{3} \mathrm{O}_{4}\right)$ foram obtidas a partir da dissolução de $8,5820 \mathrm{~g}$ de cloreto ferroso tetrahidratado $\left(\mathrm{FeCl}_{2} \cdot 4 \mathrm{H}_{2} \mathrm{O}\right)$, Merck, em $200 \mathrm{~mL}$ de $\mathrm{H}_{2} \mathrm{O}$ destilada, obtendo-se uma solução de $\mathrm{pH}$ entre 2 e 3, e 23,4195 g de cloreto férrico hexahidratado $\left(\mathrm{FeCl}_{3} \cdot 6 \mathrm{H}_{2} \mathrm{O}\right)$, Merck, também dissolvido com o mesmo volume de $\mathrm{H}_{2} \mathrm{O}$ destilada, apresentando um pH entre 1 e 2. A FIG. 16 ilustra todas as etapas de preparação da magnetita.

Os sais dissolvidos foram misturados em um béquer de $1000 \mathrm{~mL}$ e 0 volume foi completado até $600 \mathrm{~mL}$ com água destilada. A adição lenta, $1 \mathrm{~mL}$ por vez, de uma solução de $\mathrm{NaOH} 5 \mathrm{~mol}^{-1}$ ao meio promoveu a precipitação simultânea dos íons $\mathrm{Fe}^{2+}$ e $\mathrm{Fe}^{3+}$, ( equação 5). $\mathrm{O} \mathrm{pH}$ foi medido a cada $1 \mathrm{~mL}$, até atingir 10,8, formando um precipitado de coloração preta. Para que se obtivesse o máximo de precipitado, a parede do béquer foi lavada com $\mathrm{H}_{2} \mathrm{O}$ destilada a cada $\mathrm{mL}$ acrescentado, alcançando um volume final de $900 \mathrm{~mL}$. Essa etapa foi realizada sob a agitação constante com um dispersor extratur, modelo Q-252K28, Quimis, com uma haste de dispersão acoplada, cuja velocidade foi fixada em $10.000 \mathrm{rpm}$.

$$
\mathrm{Fe}^{2+}+2 \mathrm{Fe}^{3+}+8 \mathrm{OH}^{-} \rightarrow \mathrm{FeO}^{2} \mathrm{Fe}_{2} \mathrm{O}_{3}+4 \mathrm{H}_{2} \mathrm{O}
$$

A solução contendo as partículas magnéticas de magnetita repousou por 60 min, sendo eventualmente movimentada por meio de agitação manual do recipiente. O béquer foi colocado sobre um imã, e a separação magnética das fases sólida-líquida foi concluída após $10 \mathrm{~min}$, obtendo-se aproximadamente 100 $\mathrm{mL}$ de material sedimentado, $\mathrm{com} \mathrm{pH} 10,8$. O líquido foi retirado cuidadosamente, sendo descartado. $\mathrm{O}$ precipitado foi lavado 5 vezes com $\mathrm{H}_{2} \mathrm{O}$ destilada com 0 objetivo de se alcançar o pH próximo de 7,0, sendo separado magneticamente a cada lavagem. O sobrenadante foi descartado em todas as lavagens.

Após a última lavagem acrescentou-se $\mathrm{H}_{2} \mathrm{O}$ destilada ao sedimentado, até completar o volume de $250 \mathrm{~mL}$. O béquer foi colocado sobre uma mesa agitadora, modelo Q225M, Quimis, à velocidade de $180 \mathrm{rpm}$. Em seguida, o material repousou por 17 horas. 
O béquer com solução de partículas magnéticas sedimentadas foi colocado sobre o imã para a separação magnética. A parte líquida foi descartada e a massa úmida foi fracionada em 2 partes. A fração menor denominada MU1, com aproximadamente $2,5 \mathrm{~g}$, foi colocada em uma placa de Petri para secagem a fim de obter a magnetita em pó. A outra fração foi ressuspendida em $400 \mathrm{~mL}$ de água destilada e encaminhada para revestimento com o biopolímero quitosana. 


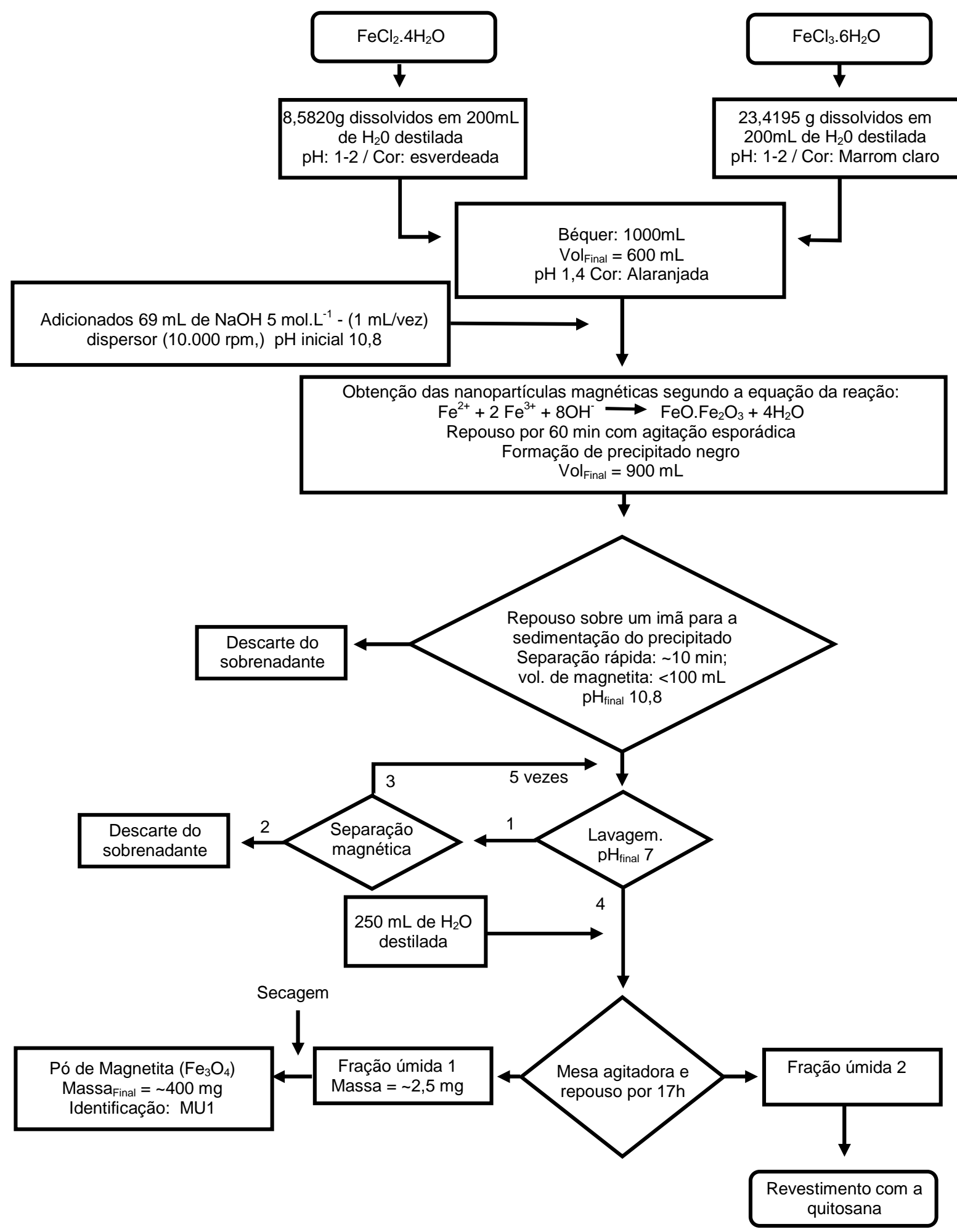

FIGURA 16 - Produção de partículas magnéticas de magnetita $\left(\mathrm{Fe}_{3} \mathrm{O}_{4}\right)$. 


\section{IV.3. Preparação da quitosana}

Prepararam-se $250 \mathrm{~mL}$ de ácido acético $(2 \%, \mathrm{v} / \mathrm{v})$ em $\mathrm{H}_{2} \mathrm{O}$ destilada. $\mathrm{O}$ béquer foi colocado sobre uma mesa agitadora e a velocidade mantida a $300 \mathrm{rpm}$. Pesaram-se 4,4365 g de quitosana em flocos, peso molecular médio, da Aldrich, e adicionou-se lentamente o biopolímero ao béquer contendo a solução de ácido acético. Após 4 h obteve-se a solução de quitosana, com coloração clara e pH 2. A solução foi filtrada para a retirada de resíduos não dissolvidos. O material filtrado foi colocado em um béquer de $2000 \mathrm{~mL}$ e o volume foi completado com $\mathrm{H}_{2} \mathrm{O}$ destilada até $500 \mathrm{~mL}$. Uma parte da solução $(\sim 30 \mathrm{~mL})$ foi separada e colocada em recipientes plásticos para secagem à temperatura ambiente para a produção de filmes de quitosana. A outra parte foi encaminhada para o revestimento das partículas magnéticas.

\section{IV.4. Revestimento das partículas magnéticas de magnetita com quitosana (Quitosana Magnética - QM)}

O revestimento das partículas magnéticas pela quitosana está esquematizado na FIG. 17. O béquer contendo a solução de quitosana foi colocado sobre a mesa agitadora, que foi mantida a $150 \mathrm{rpm}$. Utilizou-se o dispersor a $10.000 \mathrm{rpm}$.

A suspensão de magnetita foi despejada lentamente no béquer contendo a quitosana dissolvida, e após $1 \mathrm{~h}$ obteve-se uma solução contendo uma suspensão de particulados pretos, os quais neste trabalho foram denominados quitosana magnética (QM). O volume foi completado até $1100 \mathrm{~mL}$. $\mathrm{O}$ dispersor foi retirado e a solução foi mantida em agitação por $4 \mathrm{~h}$ na mesa agitadora a $150 \mathrm{rpm}$, repousando em seguida por $15 \mathrm{~h}$. O recipiente com QM foi colocado sobre um imã para a separação magnética do sólido do líquido, sendo o sobrenadante desprezado. A etapa constituída de separação magnética seguida pela lavagem da $\mathrm{QM}$ com $\mathrm{H}_{2} \mathrm{O}$ destilada e descarte do sobrenadante foi realizada 1 vez.

A massa úmida resultante após o descarte do sobrenadante foi dividida em 3 porções: QM1, QM2 e QM3. Cada fração foi colocada em um béquer e o volume foi completado até $250 \mathrm{~mL}$ com $\mathrm{H}_{2} \mathrm{O}$ destilada. $\mathrm{O} \mathrm{pH}$ medido foi de 4,9.

Antes de serem encaminhadas para reação com o glutaraldeído, a QM foi tratada por diferentes procedimentos. 

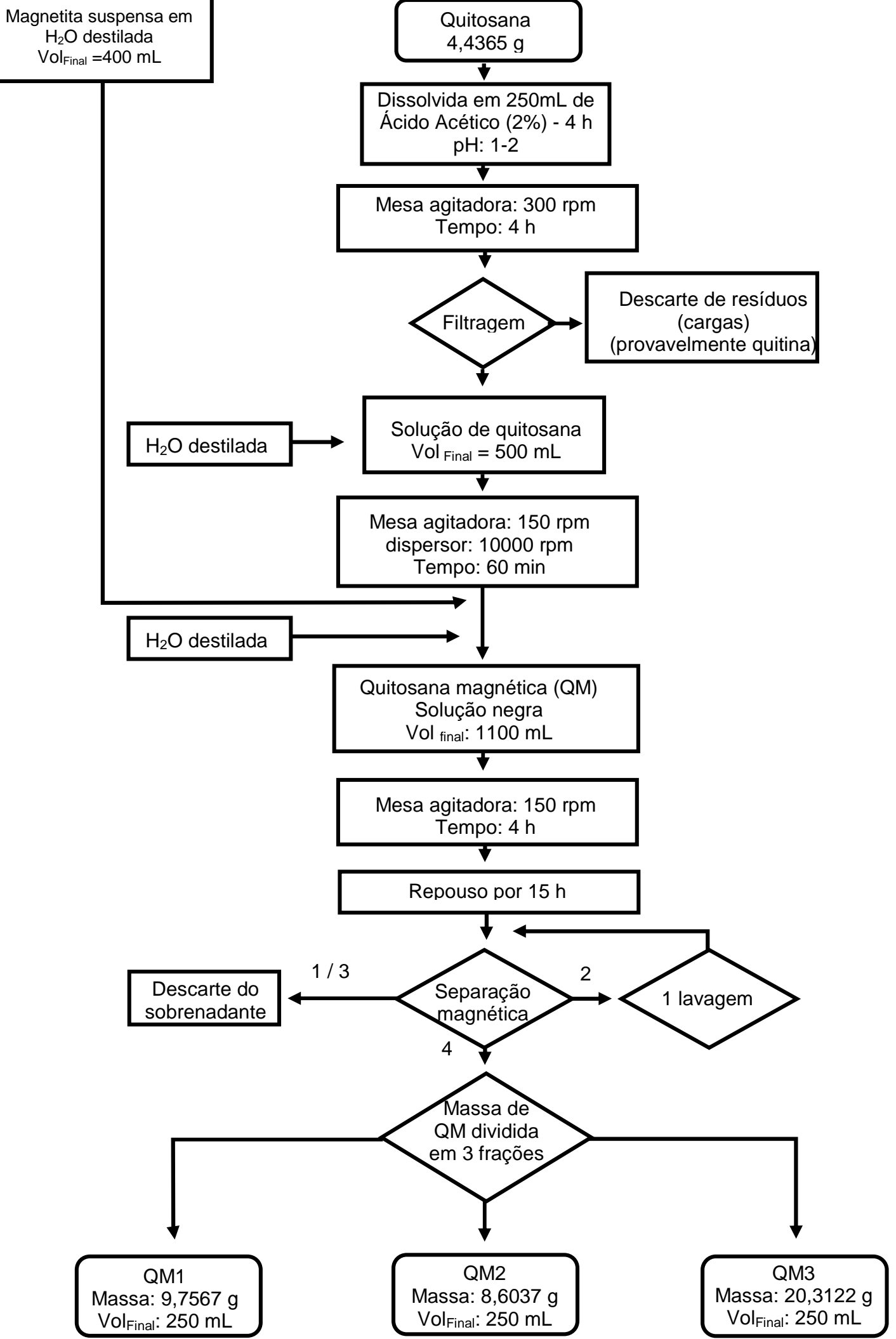

FIGURA 17 - Revestimento das partículas magnéticas de magnetita com a quitosana. Obtenção da QM. 


\section{IV.5. Tratamento da superfície da quitosana magnética (QM)}

A amostra QM3 foi mantida em suspensão sem nenhum tratamento superficial.

À amostra QM2 foi acrescentada lentamente uma solução de $\mathrm{NaOH} 5$ mol. $\mathrm{L}^{-1}$ para a precipitação da quitosana, sendo necessário $1 \mathrm{~mL}$ do hidróxido de sódio até atingir o pH 11,9. Nessa etapa, a solução foi agitada por meio do dispersor a 5.000 rpm. Os béqueres contendo as amostras QM1 e QM2, repousaram sobre o imã por 20 h, e apresentaram uma separação sólido-líquido eficiente. Após o pernoite, o sobrenadante foi descartado e ambas foram submetidas a separação magnética, lavagens e descartes do sobrenadante, até que se completassem 3 ciclos desse procedimento. Ao fim desses ciclos, observaram-se as mudanças do $\mathrm{pH}$, que passou de 4,7 para 5 na amostra QM1, e de 11,9 para 9 na QM2.

Além disso, a QM2 foi lavada 2 vezes com acetona, para acelerar o processo de secagem, e o produto final foi chamado de QM2Na. A QM1 e a QM2Na foram colocadas em placa de Pétri para secagem à temperatura ambiente. A QM1 se desidratou em 5 dias e a QM2Na em 1 dia. Uma fração de cada amostra (QM1, QM2Na e QM3) foi separada e preservada para as devidas caracterizações; a outra parcela foi encaminhada para a reticulação, funcionalização e imobilização de proteínas (FIG. 18). 


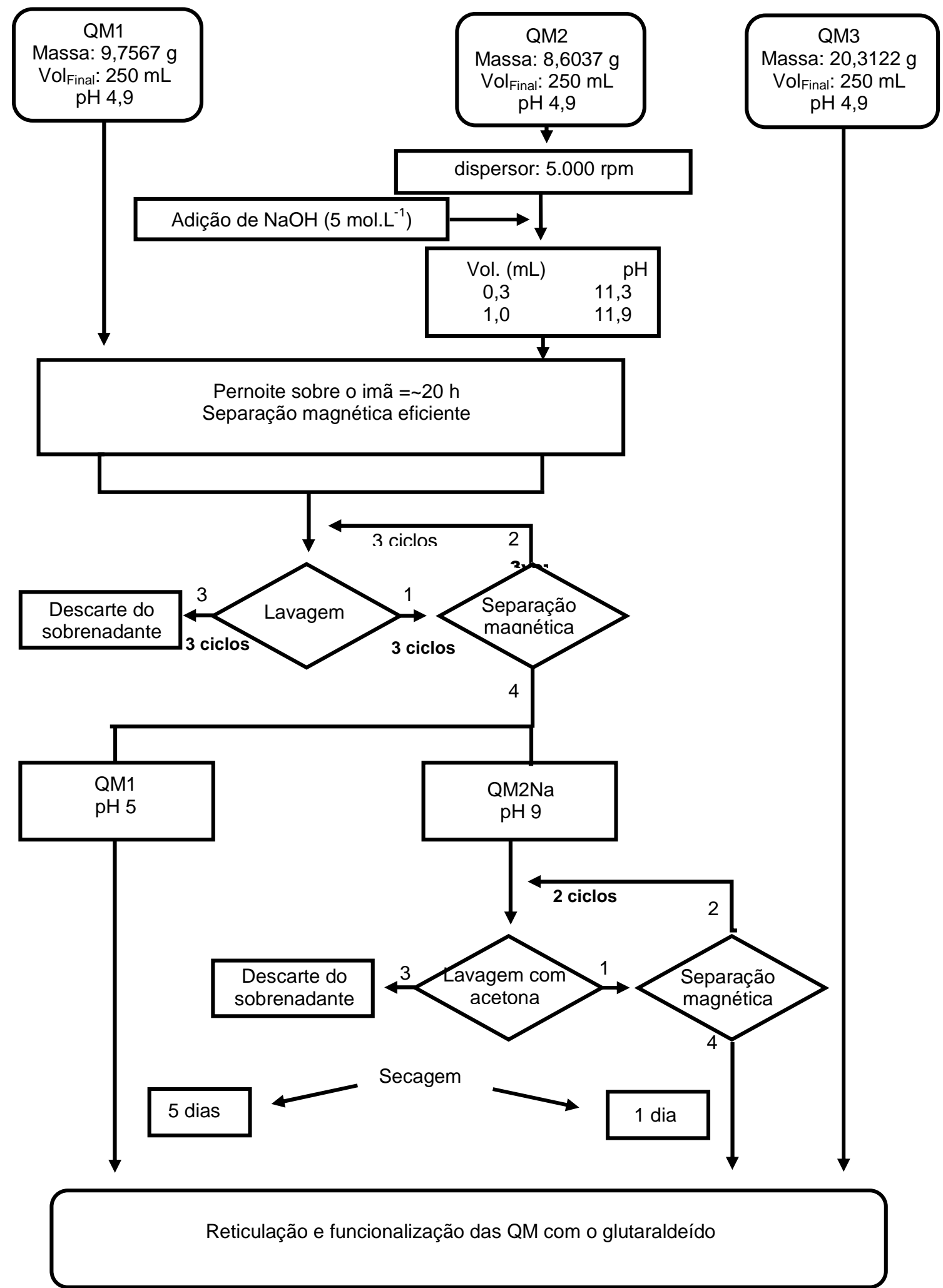

FIGURA 18 - Preparação da QM para a reação com o glutaraldeído. 


\section{IV.6. Reticulação e funcionalização da QM com o glutaraldeído}

As partículas de QM foram reticuladas e funcionalizadas com o agente bifuncional glutaraldeído, segundo o procedimento ilustrado na FIG. 19. Separaram-se $50 \mathrm{mg}$ de QM1 e QM2Na e $1 \mathrm{~mL}$ de QM3, os quais foram colocados separadamente em frascos de vidro de $5 \mathrm{~mL}$, acrescentando-se $1 \mathrm{~mL}$ de glutaraldeído $(5 \%, v / v)$. Todos os ensaios foram realizados em duplicata.

Os frascos foram acondicionados em béqueres e colocados sobre uma mesa agitadora, com a velocidade fixada em $180 \mathrm{rpm}$, onde permaneceram por um período de $4 \mathrm{~h}$. Após esse tempo, foram colocados sobre um imã por $30 \mathrm{~min}$ para separação das fases sólida-líquida. O sobrenadante foi descartado. As QM foram lavadas 4 vezes com $\mathrm{H}_{2} \mathrm{O}$ Milli-Q para a retirada do glutaraldeído que não reagiu e ficou disperso no meio. Os frascos foram colocados sobre o imã a cada lavagem para que ocorresse a separação magnética. As partículas magnéticas reticuladas e funcionalizadas foram denominadas QM1Glu, QM2NaGlu e QM3Glu. Além das QM funcionalizadas com glutaraldeído, separaram-se as QM1, QM2Na e QM3 não funcionalizadas em frascos, em duplicata, os quais foram colocados sobre o imã para a separação magnética e o sobrenadante descartado. As QM foram encaminhadas para a imobilização com as proteínas. 


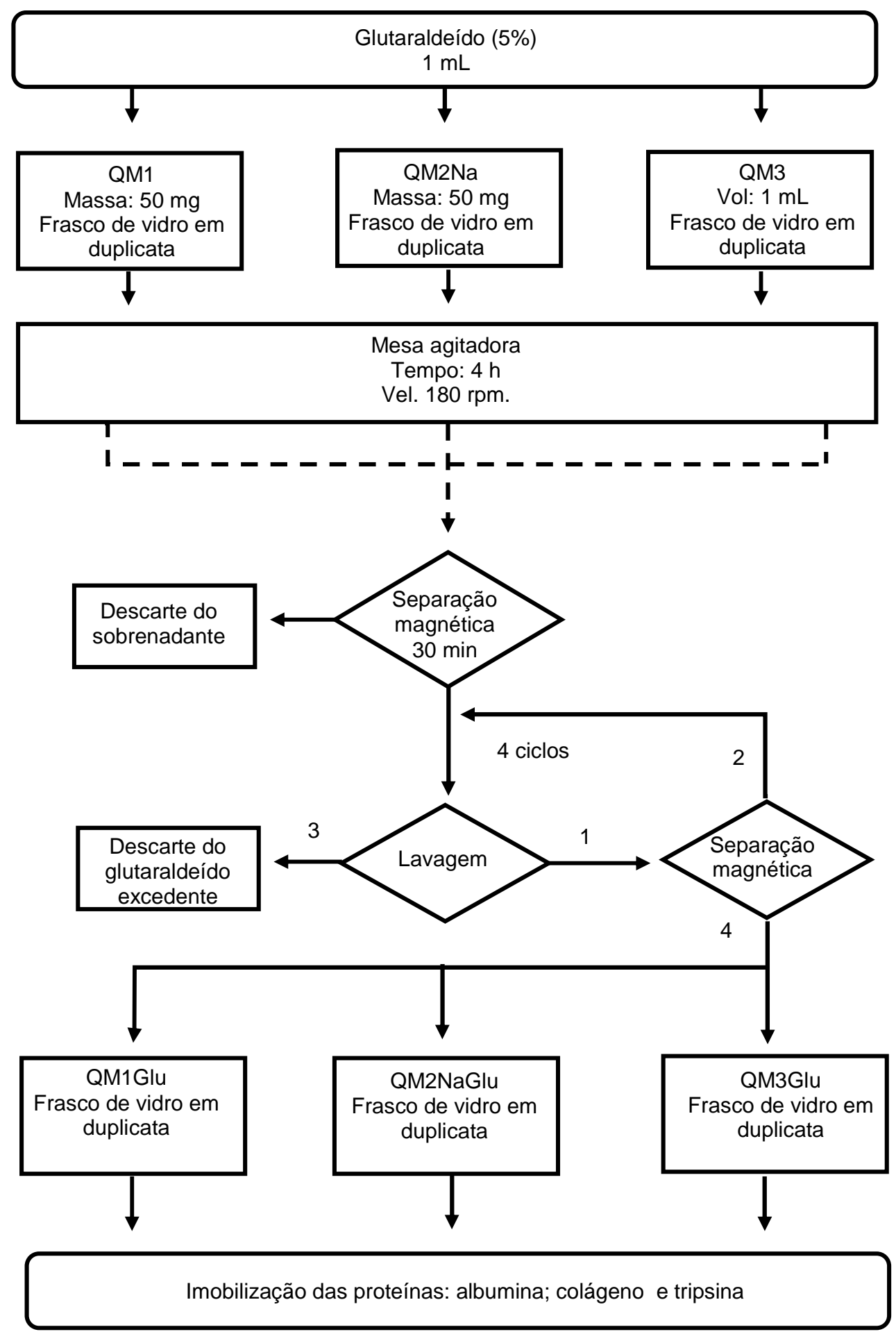

FIGURA 19 - Reticulação e funcionalização da quitosana presente nas QM com o glutaraldeído. 


\section{IV.7. Preparação das proteínas cargas (Prot-carga)}

As proteínas-cargas foram preparadas na concentração de $0,1 \mathrm{mg} \cdot \mathrm{mL}^{-1}$ e $2 \mathrm{mg} \cdot \mathrm{mL}^{-1}$. Após a dissolução, as proteínas foram mantidas em geladeira a uma temperatura média de $4^{\circ} \mathrm{C}$ para a preservação de suas propriedades.

A albumina (BSA, Sigma-Aldrich) foi dissolvida em $\mathrm{H}_{2} \mathrm{O}$ Milli-Q, à temperatura ambiente.

O Colágeno (Sigma-Aldrich) foi dissolvido em $\mathrm{H}_{2} \mathrm{O}$ Milli-Q, em banho termostático, à temperatura de $37^{\circ} \mathrm{C}$.

A tripsina de porco (Sigma-Aldrich) foi dissolvida em tampão Tris-HCl $80 \mathrm{mM}, \mathrm{pH} 8,1$, contendo $\mathrm{CaCl}_{2}, 20 \mathrm{mM}$, à temperatura ambiente.

\section{IV.8. Imobilização de proteínas na superfície das QMs funcionalizadas (QM1Glu, QM2NaGlu e QM3Glu) e não funcionalizada (QM3).}

Os frascos, em duplicata, contendo as partículas magnéticas, QM1Glu, QM2NaGlu, QM3Glu e QM3, foram separados em 3 grupos para a imobilização com as proteínas BSA, colágeno e tripsina (concentração $0,1 \mathrm{mg} \cdot \mathrm{mL}^{-1}$ e 2,0 $\mathrm{mg} \cdot \mathrm{mL}^{-1}$ ), denominadas proteína-carga. Em cada frasco foi adicionado $1 \mathrm{~mL}$ de proteína. Os frascos foram acondicionados em béqueres e colocados sobre mesa agitadora a 180 rpm. Todo procedimento de imobilização está esquematizado na FIG. 20. As QM foram mantidas em contato com as proteínas em tempos diferentes de incubação, de acordo com a TAB. 3, para a otimização do tempo de imobilização.

TABELA 3 - Tempo de incubação das QM com as proteínas (concentração 0,1 $\mathrm{mg} \cdot \mathrm{mL}^{-1}$ e 2,0 mg.mL ${ }^{-1}$ ).

Tempo de incubação (min)

\begin{tabular}{ccc}
\hline Proteína & QM3 & QM1Glu, QM2NaGlu, QM3Glu \\
\hline BSA, Colágeno & 180 & $30 ; 60 ; 120 ; 180 ; 300$ \\
\hline Tripsina & 60 & $30 ; 60 ; 180 ; 300$ \\
\hline
\end{tabular}




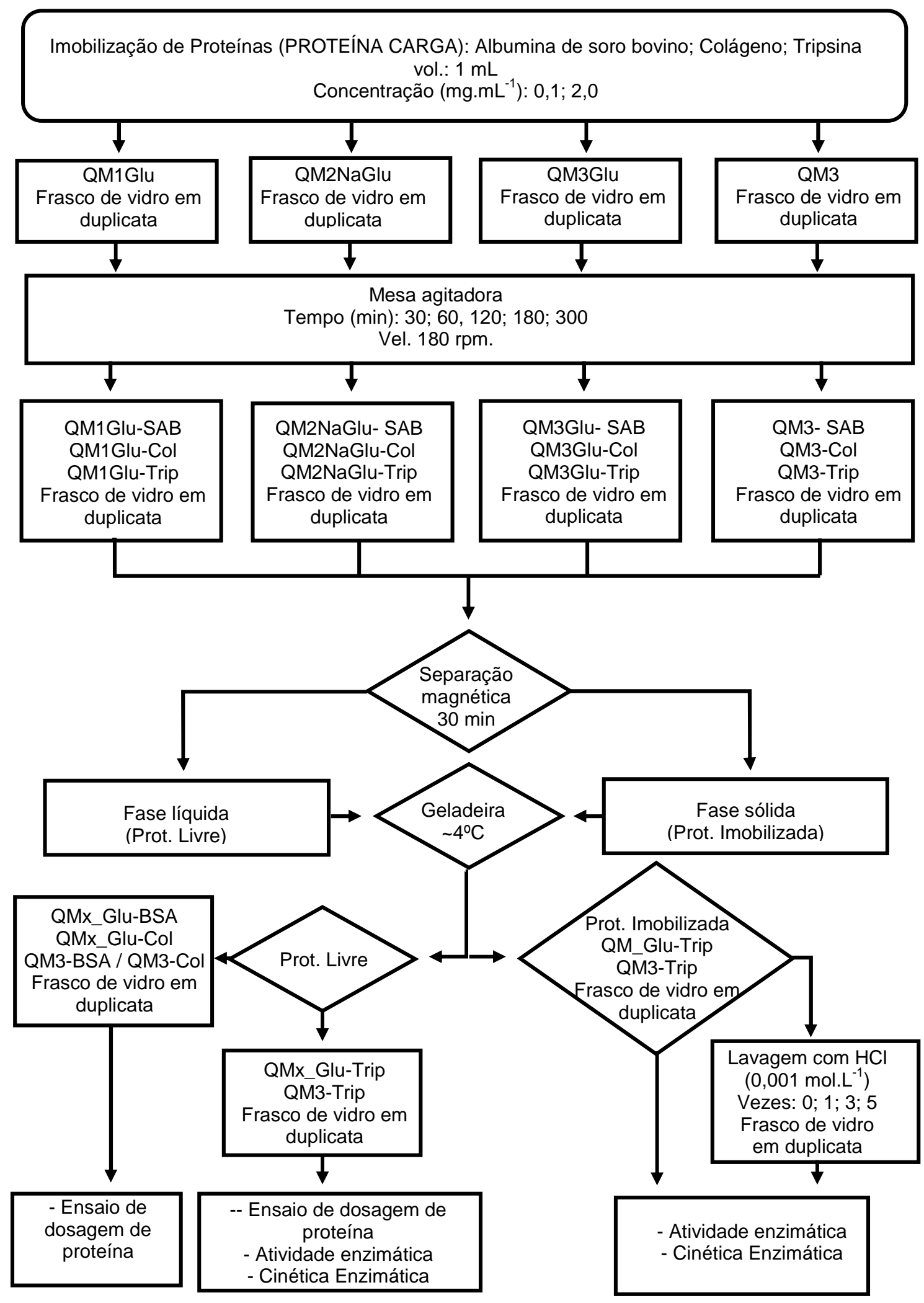

FIGURA 20 - Imobilização de proteínas na superfície das QM.

QMx_Glu-proteína = partículas QM funcionalizadas com o glutaraldeído com proteína imobilizada. 
IV.8.1.Separação das fases sólida-líquida (proteína imobilizada-proteína livre, respectivamente)

Após alcançar cada tempo de contato, efetuou-se a separação magnética, obtendo-se uma fase sólida (proteína imobilizada) e outra líquida (proteína livre). Ambas foram mantidas em geladeira ( $\left.4^{\circ} \mathrm{C}\right)$ para a preservação das suas propriedades (FIG. 20).

\section{IV.8.2. Remoção da proteína não imobilizada nas partículas magnéticas}

As partículas imobilizadas com a tripsina $\left(0,1 \mathrm{mg} \cdot \mathrm{mL}^{-1}\right)$ foram lavadas com $\mathrm{HCl}$ 0,001 mol. $\mathrm{L}^{-1}$, visando à retirada da enzima que supostamente estivesse apenas em contato superficial (FIG. 20 e TAB. 4); depois foram lavadas 1 vez com tampão Tris- $\mathrm{HCl}$, sendo mantidas em suspensão de $500 \mu \mathrm{L}$ do mesmo tampão.

TABELA 4 - Partículas magnéticas imobilizadas com a tripsina (180 min de contato) e lavadas com $\mathrm{HCl} 0,001 \mathrm{~mol}^{-1}$, para a retirada de enzima livre.

\begin{tabular}{ccc}
\cline { 2 - 3 } & \multicolumn{2}{c}{ Partículas magnéticas } \\
\cline { 2 - 3 } & QM3-Trip $\begin{array}{c}\text { QM1Glu-Trip; QM2NaGlu-Trip } \\
\text { e QM3Glu-Trip }\end{array}$ \\
\hline $\begin{array}{c}\text { Número de lavagens } \\
\text { (vezes) }\end{array}$ & 5 & $0 ; 1 ; 3 ; 5$ \\
\hline
\end{tabular}

As amostras, inclusive a proteína-carga, foram encaminhadas para os ensaios de dosagem de proteína, atividade enzimática e cinética enzimática. 


\section{IV.9. Caracterização}

\section{IV.9.1. Microscopia eletrônica de varredura (MEV)}

As amostras foram recobertas com ouro e as fotomicrografias foram obtidas com ampliação entre 10.000 e 20.000x, empregando-se um microscópio eletrônico de varredura (MEV), modelo JEOL 200C de 200 kV, do Laboratório de Microscopia do IPEN (CCTM/IPEN).

\section{IV.9.2. Difratometria de raios $X$}

Utilizou-se um difratômetro Rigaku modelo MultiFlex, radiação de CuKa1 $(\lambda=1,5406 \AA$ ) , a 40 kV e 20 mA, do Centro de Ciência e Tecnologia de Materiais do IPEN (CCTM/IPEN). O tamanho do cristalito foi estimado por meio da equação de Scherrer (equação 6), que relaciona a largura da meia altura dos picos com o tamanho de cristalito. Pela equação estima-se que quanto maior a largura dos picos $(\boldsymbol{\beta})$ menor é o tamanho do cristalito [CULLITY e GRAHAM, 2009].

$$
d=\frac{K \lambda}{\beta \cos \theta}
$$

sendo:

$\boldsymbol{d}=$ diâmetro médio das partículas $(\stackrel{\AA}{)})$

$\boldsymbol{k}=$ constante de proporcionalidade que depende da forma das partículas, assumida como sendo esférica, portanto nesse caso $k=0,9$

$\lambda=$ comprimento de onda $(\mathbf{1 , 5 4 0 6} \AA$ ̊̊) da radiação incidente CuKa 1

$\boldsymbol{\beta}=$ largura na meia altura do pico (radianos)

$\boldsymbol{\theta}=$ ângulo Bragg 


\section{IV.9.3. Magnetometria de amostra vibrante (MAV)}

Intervalo de análise de -20 a $+20 \mathrm{kOe}$, à temperatura de $300 \mathrm{~K}$, utilizando o magnetômetro de amostra vibrante (MAV), marca EG\&G Princeton Applied Research, modelo 4500, do Laboratório de Materiais Magnéticos, Física, USP.

\section{IV.9.4. Calorimetria exploratória diferencial (DSC)}

Os ensaios foram executados no intervalo de temperatura de $25^{\circ} \mathrm{C}$ à $550^{\circ} \mathrm{C}$, razão de aquecimento de $10^{\circ} \mathrm{C} \cdot \mathrm{min}^{-1} \mathrm{sob}$ atmosfera de $\mathrm{N}_{2}$, vazão de 50 $\mathrm{mL} \cdot \mathrm{min}^{-1}$, capsula de alumínio de $40 \mu \mathrm{L}$; sendo tampa furada automaticamente, com $10 \mathrm{mg}$ de massa de amostra, empregando a célula calorimétrica modelo DSC 822e (Mettler Toledo Calibração: foi utilizado o Indio como padrão de calibração (Temperatura de pico: $\sim 156^{\circ} \mathrm{C}$ ). Laboratório de Polímeros do Centro de Química e Meio Ambiente do IPEN (CQMA/IPEN).

\section{IV.9.5. Termogravimetria (TG)}

Os ensaios foram executados no intervalo de temperatura de $25^{\circ} \mathrm{C}$ à $800^{\circ} \mathrm{C}$, razão de aquecimento de $10^{\circ} \mathrm{C} \cdot \mathrm{min}^{-1}$, sob atmosfera de $\mathrm{N}_{2}$, vazão de 50 $\mathrm{mL} \cdot \mathrm{min}^{-1}$, cadinho de alumina de $70 \mu \mathrm{L}$, com $20 \mathrm{mg}$ de massa de amostra, empregando uma termobalança modelo TGA/SDTA 851 (Mettler Toledo) Calibração: foram utilizados o Indio e o Alumínio como padrões de calibração (Temperatura de pico: $\sim 156^{\circ} \mathrm{C}$ e $\sim 660^{\circ} \mathrm{C}$, respectivamente). Laboratório de Polímeros do Centro de Química e Meio Ambiente do IPEN (CQMA/IPEN).

\section{IV.9.6. Espectroscopia na região do Infravermelho por transformada de Fourier (FTIR)}

Os ensaios foram obtidos no intervalo de número de onda de 4000 à $400 \mathrm{~cm}^{-1}$; foram ensaiados dois tipos de amostras: filmes de quitosana ensaiados por meio da técnica de reflexão (ATR); e partículas magnéticas (MU1; QM1 e QM2Na) preparadas no formato de pastilhas diluídas em $\mathrm{KBr}$, empregando um espectrômetro de infravermelho por transformada de Fourier (FTIR), Nicolet, modelo 4700, do Laboratório Caracterização de Materiais do Centro Tecnológico da Marinha em São Paulo (LACAM/CTMSP) 


\section{IV.10. Ensaio biológico}

Após a imobilização das proteínas, efetuou-se a separação magnética obtendo-se duas fases, a proteína livre (Prot-livre) e as partículas magnéticas com a proteína imobilizada (Prot-imob), as quais foram mantidas em frascos individuais para o ensaio de dosagem do conteúdo protéico. Para as partículas com tripsina realizaram-se também os ensaios de atividade enzimática com determinação dos parâmetros cinéticos.

A distribuição dos ensaios biológicos está esquematizada na TAB. 5 para cada tipo de amostra.

Utilizaram-se o espectrofotômetro de UV-Vis, modelo Ultrospec III, da marca Pharmacia LKB, localizado no Centro de Biotecnologia do IPEN (CB/IPEN), e cubetas semimicro de poliestireno (Sigma-Aldrich), com volume de 1,5 mL, e caminho óptico $10 \mathrm{~mm}$. As leituras foram realizadas em $595 \mathrm{~nm}$ para o ensaio de dosagem de proteína e em $410 \mathrm{~nm}$ para o de atividade enzimática. 
TABELA 5 - Distribuição das amostras para os ensaios no espectrofotômetro UV/visível.

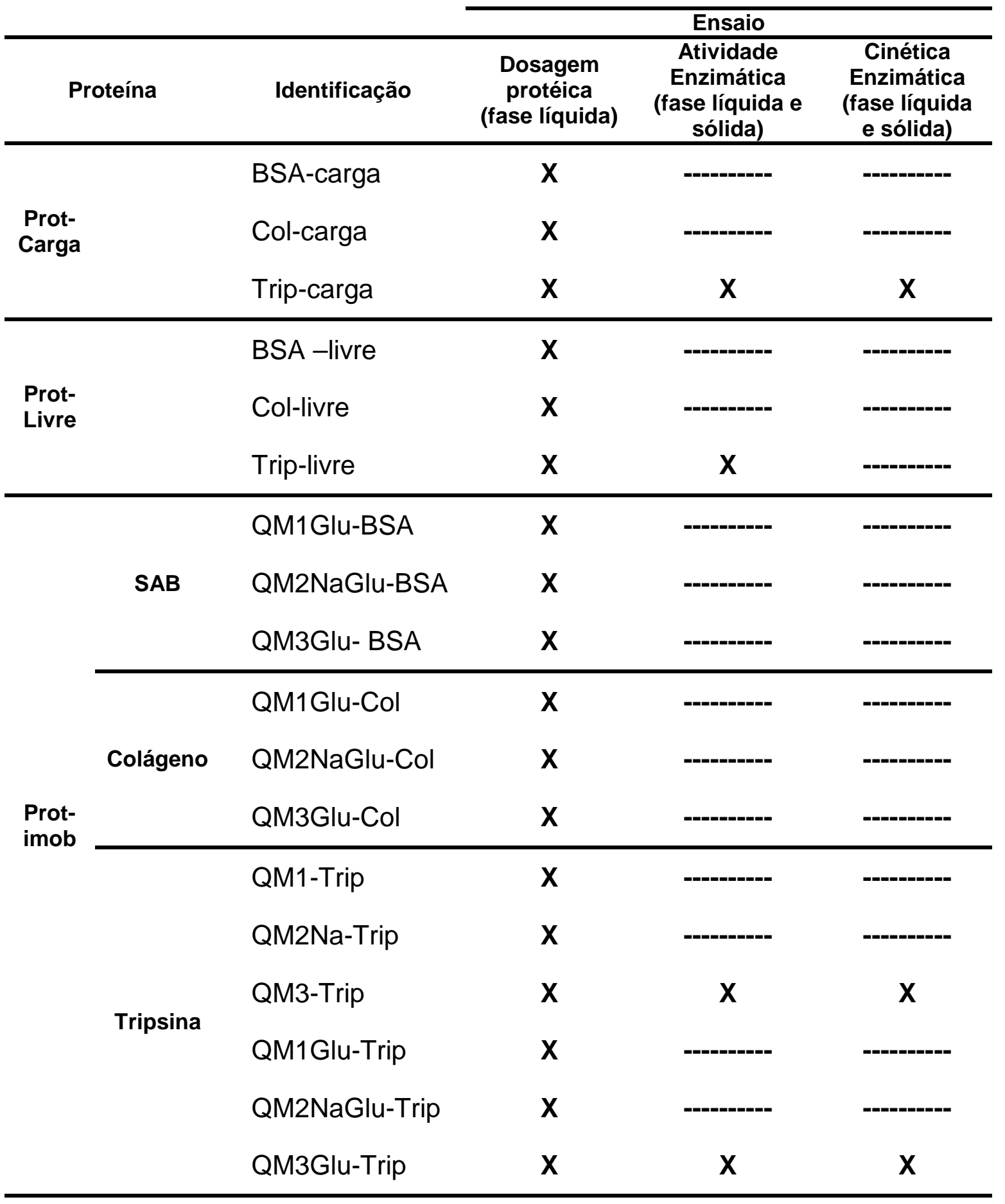

Nota: BSA-carga / Col-carga / Trip-carga = proteínas dissolvidas de onde foram retiradas alíquotas $(1 \mathrm{~mL})$ para imobilização nas partículas magnéticas;

BSA-livre / Col-livre / Trip-livre = proteína residual no sobrenadante resultante da separação magnética após o contato com as QM (após a imobilização);

QM1-, QM2Na-, QM3-Trip = partículas $Q M$ não funcionalizadas, com proteínas imobilizadas;

QM1GIu-, QM2NaGIu-, QM3GIu-SAB/Col/Trip = partículas QM funcionalizadas com o glutaraldeído, com proteínas imobilizadas. 


\section{IV.10.1. Dosagem de proteína}

A concentração protéica das amostras foi determinada pela metodologia de BRADFORD (1976) modificada, a qual baseia-se na capacidade das proteínas interferirem na absorbância do corante Coomassie Brilliant Blue G250, em meio altamente ácido, resultando em modificação gradual da cor, detectável em $595 \mathrm{~nm}$.

A finalidade desse ensaio foi determinar o tempo necessário de incubação, a eficácia da imobilização, e qual proteína respondeu melhor à imobilização nas partículas magnéticas QM.

Para cada ensaio foi construída uma curva padrão tendo como referência a albumina de soro bovino (BSA) diluída em água (pureza grau Milli-Q), na concentração $1 \mathrm{mg} \cdot \mathrm{mL}^{-1}$. Foram feitas diluições seriadas obtendo-se as concentrações de $0,5 \mathrm{mg} \cdot \mathrm{mL}^{-1} ; 0,25 \mathrm{mg} \cdot \mathrm{mL}^{-1} ; 0,125 \mathrm{mg} \cdot \mathrm{mL}^{-1} ; 0,0625 \mathrm{mg} \cdot \mathrm{mL}^{-1}$, $0,03125 \mathrm{mg} \cdot \mathrm{mL}^{-1}, 0,0156 \mathrm{mg} \cdot \mathrm{mL}^{-1}$ (diluições $1: 2 ; 1: 4 ; 1: 8 ; 1: 16 ; 1: 32$ e 1:64).

Para a reação, um volume de $950 \mu \mathrm{L}$ do reagente de Bradford foi adicionado a $50 \mu \mathrm{L}$ de cada diluição, em duplicata.

Nos ensaios com a proteína-carga e a proteína livre pipetaram-se 50 $\mu \mathrm{L}$ de cada amostra em microtubos (TAB. 7), e adicionaram $950 \mu \mathrm{L}$ do reagente de Bradford, agitando-os levemente em um vórtex.

Após 15 minutos realizou-se a leitura no espectrofotômetro. Todas as amostras foram analisadas em duplicata.

Os dados da curva padrão foram ajustados por meio do aplicativo Origin, pela regressão linear com a equação $Y=a X+b$ para calcular $a$ concentração protéica das amostras, sendo (Y) a densidade óptica, (X) a concentração protéica, (a) o coeficiente angular da reta e (b) o intercepto da reta.

\section{IV.10.2. Atividade enzimática}

Os ensaios de atividade enzimática foram realizados segundo 0 método de MAGALHAES et al. (1993) baseado em ERLANGER et al. (1961).

As frações de tripsina foram incubadas com o substrato sintético BApNA (N-Benzoil-DL-arginina-p-nitroanilida), marca SIGMA. A solução estoque do substrato $\left(9,0 \times 10^{-2} \mathrm{~mol}^{-1} \mathrm{~L}^{-1}\right)$ foi preparada pela dissolução de $196 \mathrm{mg}$ do composto em $5 \mathrm{~mL}$ de dimetilsulfóxido e armazenado a $-20^{\circ} \mathrm{C}$. A solução de uso foi preparada pela diluição 1:100 da solução estoque em tampão Tris $\mathrm{HCl} 0,1$ 
mol. $\mathrm{L}^{-1}, \mathrm{pH} 8,0$. Esse substrato cromogênico é clivado pela tripsina, liberando o composto corado $p$-nitroanilida, detectável em $410 \mathrm{~nm}$.

Neste ensaio estudou-se a tripsina imobilizada nas partículas magnéticas na ausência e presença de glutaraldeído após 5 dias e 30 dias de imobilização.

\section{IV.10.2.1. Procedimento}

Pipetaram-se em microtubos $50 \mu \mathrm{L}$ de Trip-livre e, em seguida, $950 \mu \mathrm{L}$ de $B A p N A$, sendo acionado um cronômetro para determinação do tempo de reação.

O mesmo procedimento foi adotado para a Trip-carga e as Trip-imob (QM3-Trip e QM3Glu-Trip, previamente suspensas em tampão).

Em outro microtubo foram colocados $1000 \mu \mathrm{L}$ do substrato para ser usado como branco.

As soluções foram incubadas em banho termostático, estabilizado à $37^{\circ} \mathrm{C}$, por $20 \mathrm{~min}$, com agitação manual e esporádica dos recipientes.

Decorrido o tempo de incubação, os microtubos foram retirados do tratamento térmico e transferidos para um recipiente com gelo, com o objetivo de interromper a reação enzima/substrato.

As leituras no espectrofotômetro foram realizadas à temperatura de 25 $\pm 2^{\circ} \mathrm{C}$.

Nas amostras QM3-Trip e QM3Glu-Trip foi colocado um imã na parede externa do microtubo para o aprisionamento das partículas magnéticas, separando-as da fração líquida. Esta foi cuidadosamente retirada com uma micropipeta volumétrica e transferida para uma cubeta semi-micro para a leitura em $410 \mathrm{~nm}$.

\section{IV.10.3. Cinética enzimática}

Antes de se iniciar a descrição dos procedimentos dos ensaios com a enzima, é necessário observar alguns parâmetros importantes:

- para se obter um bom ensaio de cinética enzimática, há a necessidade de se realizar as leituras em intervalos de tempos regulares, e na metodologia aplicada nesse trabalho foi estabelecido o intervalo de 1 min entre cada leitura; 
- o substrato (BApNA), a Trip-carga, as partículas magnéticas (QM3Trip e QM3Glu-Trip) e a solução tampão foram mantidas separadamente em banho termostático $\left(37^{\circ} \mathrm{C}\right)$ antes do início e até o final dos ensaios, para a estabilização da temperatura;

- a construção da curva de cinética enzimática foi possível dividindo-se a absorbância, obtida experimentalmente no espectrofotômetro, pelo coeficiente de absorção do substrato $\left(7,68 \times 10^{3} \mathrm{AU} \mathrm{M}^{-1} \mathrm{x} \mathrm{cm}^{-1}\right)$;

- as constantes cinéticas $\left(K_{m}\right.$ e $\left.V_{\max }\right)$ foram determinadas ensaiando-se 5 concentrações de substrato: $S 1\left(0,10 \mathrm{~mol}^{-L^{-1}}\right) ; S 2\left(0,30 \mathrm{~mol} . \mathrm{L}^{-1}\right) ; S 3\left(0,44 \mathrm{~mol} . \mathrm{L}^{-}\right.$ $\left.{ }^{1}\right) ; S 4\left(0,67 \mathrm{~mol} . \mathrm{L}^{-1}\right)$ e $S 5\left(1,00 \mathrm{~mol} . \mathrm{L}^{-1}\right)$.

\section{IV.10.3.1. Tripsina carga (Trip-carga)}

Os ensaios de cinética enzimática com a Trip-carga obedeceram a sequência estabelecida na TAB. 6, iniciando o experimento pela concentração S5.

TABELA 6 - Relação enzima/substrato para o ensaio de cinética enzimática (volume final $=1000 \mu \mathrm{L}$ ).

\begin{tabular}{cccc}
\hline Identificação & $\begin{array}{c}\text { Tampão } \\
(\mu \mathrm{L})\end{array}$ & $\begin{array}{c}\text { BApNA } \\
(\mu \mathrm{L})\end{array}$ & $\begin{array}{c}\text { Trip-carga; QM3-Trip; QM3Glu-Trip } \\
(\mu \mathrm{L})\end{array}$ \\
\hline S5 & ---- & 950 & 50 \\
S4 & 290 & 660 & 50 \\
S3 & 510 & 440 & 50 \\
S2 & 654 & 296 & 50 \\
S1 & 850 & 100 & 50 \\
\hline
\end{tabular}

Pipetaram-se $950 \mu \mathrm{L}$ do BApNA numa cubeta semimicro, efetuando-se a leitura no espectrofotômetro, o valor encontrado foi registrado como o branco, a ser subtraído nos cálculos posteriores.

O volume foi completado com $50 \mu \mathrm{L}$ da Trip-carga (concentração S5), e a cubeta foi colocada novamente no banho termostático, a $37^{\circ} \mathrm{C}$, iniciando-se $\mathrm{o}$ processo de clivagem do substrato pela enzima. O material foi agitado manualmente, e após 1 min realizou-se a leitura da absorbância no 
espectrofotômetro. A cubeta foi retirada do equipamento e recolocada no banho termostático. Esse procedimento foi repetido até a saturação da enzima.

Encerradas as leituras com a concentração $S 5$, iniciou-se a amostragem com as outras concentrações ( $S 4, S 3, S 2$ e S1), sendo adicionada a solução tampão para completar o volume final $(1000 \mu \mathrm{L})$.

\section{IV.10.3.2.Partículas magnéticas (QM3-Trip e QM3Glu-Trip)}

Da mesma forma como ocorreu com a Trip-carga, os ensaios com as partículas magnéticas iniciaram-se pelo material com maior concentração de substrato (S5). Porém, devido a presença das partículas magnéticas (QM3-Trip e QM3Glu-Trip) no meio reacional, houve a necessidade de sua retirada a cada reação, para que não interferissem nas leituras no espectrofotômetro, conforme descrição a seguir.

Em uma cubeta semimicro foram pipetados $950 \mu \mathrm{L}$ do BApNA, efetuando-se a leitura no espectrofotômetro, o valor encontrado foi registrado como o branco, a ser subtraído nos cálculos posteriores.

Em um microtubo pipetaram-se $50 \mu \mathrm{L}$ de QM3-Trip, vertendo-se dentro desse microtubo o substrato que estava na cubeta, agitando-se suavemente para dar inicio ao processo de clivagem do substrato (TAB. 6). O material foi incubado no banho termostático por aproximadamente $1 \mathrm{~min}(50 \mathrm{~s}$ de tratamento térmico e $10 \mathrm{~s}$ de manuseio até a leitura no UV/vis), com a agitação manual do recipiente. Visualmente observou-se o processo de formação do produto pela mudança de coloração, de incolor para verde-claro, devido à liberação da p-nitroanilida, ocasionada pela clivagem do substrato pela enzima.

Decorrido esse tempo, de aproximadamente $50 \mathrm{~s}$, um imã foi posicionado externamente na parede do microtubo para o aprisionamento das QM3-Trip. Com o auxílio de uma micropipeta volumétrica, retirou-se cuidadosamente a parte líquida, a qual foi colocada na cubeta, sendo a leitura realizada no espectrofotômetro. O material foi devolvido ao microtubo. Esse procedimento foi repetido até a saturação da enzima.

Conforme relatado, o experimento com o substrato mais concentrado (S5) foi realizado primeiro. Após a finalização do ensaio com a concentração $S 5$, iniciou-se as amostragens com as outras concentrações de BApNA (TAB. 6). A partir da concentração $S 4$ foi acrescentado tampão para completar o volume final 
(1000 $\mu \mathrm{L}$ ), adicionando-se o tampão ao microtubo contendo as partículas magnéticas, e repetindo-se todos os passos descritos anteriormente. A mesma sequência foi aplicada à QM3Glu-Trip.

É importante ressaltar que os experimentos de cinética enzimática, realizados no espectrofotômetro, foram interrompidos tão logo os dados coletados no equipamento começaram se tornar repetitivos, formando um patamar. A partir desse ponto ocorreu a saturação da enzima com o substrato, não havendo mais a formação do produto, tornando-se desnecessária a continuidade do ensaio, e sendo esses dados suficientes para a proposta desse trabalho.

A análise dos dados foi feita diretamente no modelo de cinética enzimática do programa GraphPad Prisma e com o gráfico dos recíprocos de Lineweaver-Burk (1/V x 1/[S].) no mesmo programa. 


\section{RESULTADOS E DISCUSSÃO}

\section{V.1. Microscopia eletrônica de varredura (MEV)}

\section{V.1.1. Filme de quitosana}

A morfologia do filme de quitosana apresentada na imagem de MEV, FIG. 21, mostrou uma superfície com detalhes de saliência e microporos distribuídos uniformemente em toda extensão do filme.

\section{V.1.2. Pós de MU1, QM1 e QM2Na}

A imagem de MEV apresentada na FIG. 22 mostra os grãos de MU1 formados por aglomerados de particulados menores de tamanho variado. Os grãos se formaram durante o processo de secagem lenta à temperatura média de $25^{\circ}$ C. A FIG. 23 mostra um grão de QM1 onde se observa uma superfície com muita saliência e rugosidade com pequena semelhança à imagem apresentada pelo filme de quitosana. O tamanho dos grãos para QM1 foram maiores do que aqueles observados para MU1. A FIG. 24 evidencia o revestimento dos grãos de MU1 com a quitosana, pois, quando esta foi reprecipitada com $\mathrm{NaOH}$, observouse a formação de particulados menores compondo o grão maior. Estas observações indicam a presença de um filme de quitosana sobre as partículas magnéticas QM1 e QM2Na. 

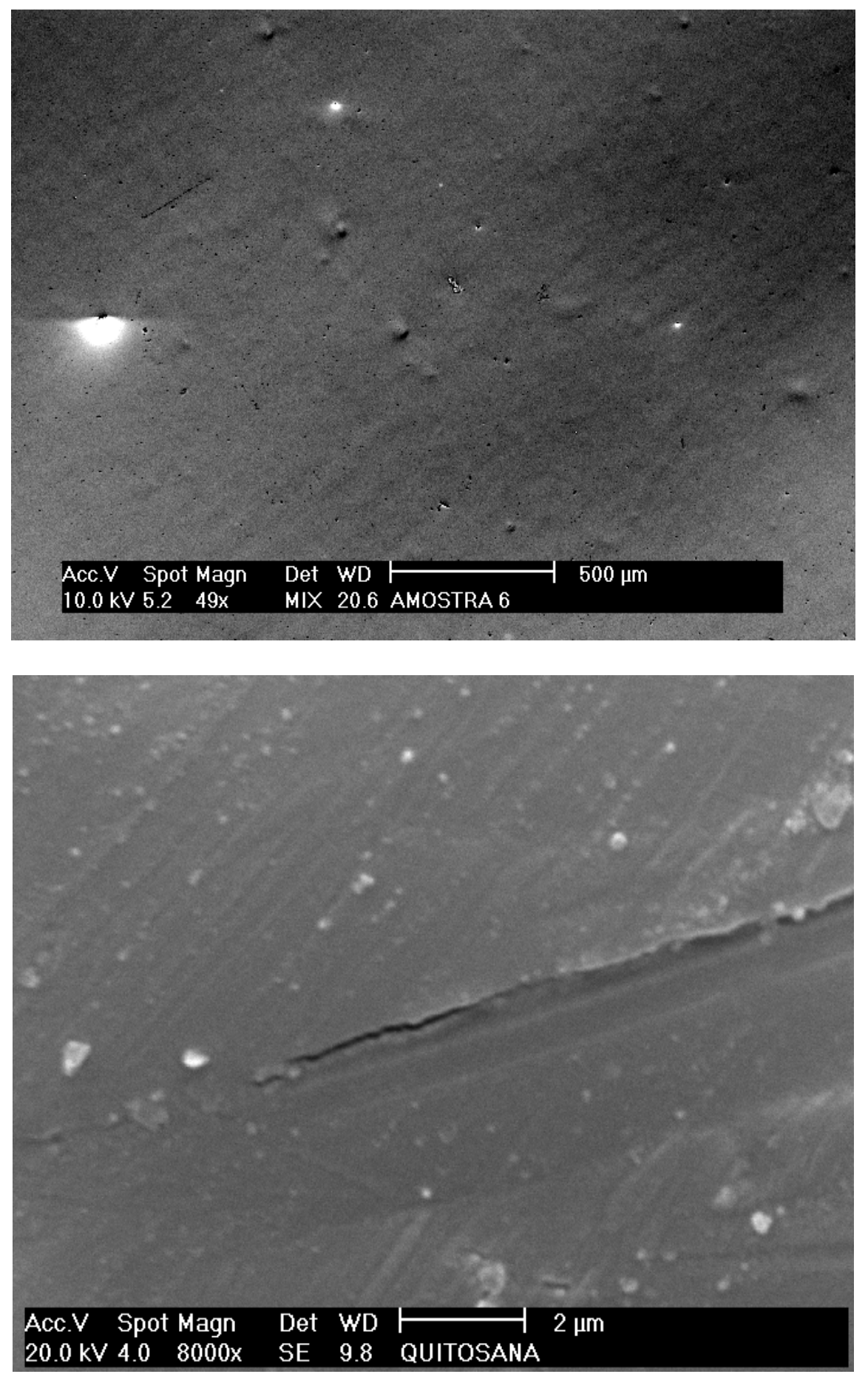

FIGURA 21 - Imagens de MEV do filme de quitosana obtido por dissolução com ácido acético e secagem à temperatura ambiente. Ampliação 49x e 8.000x. 


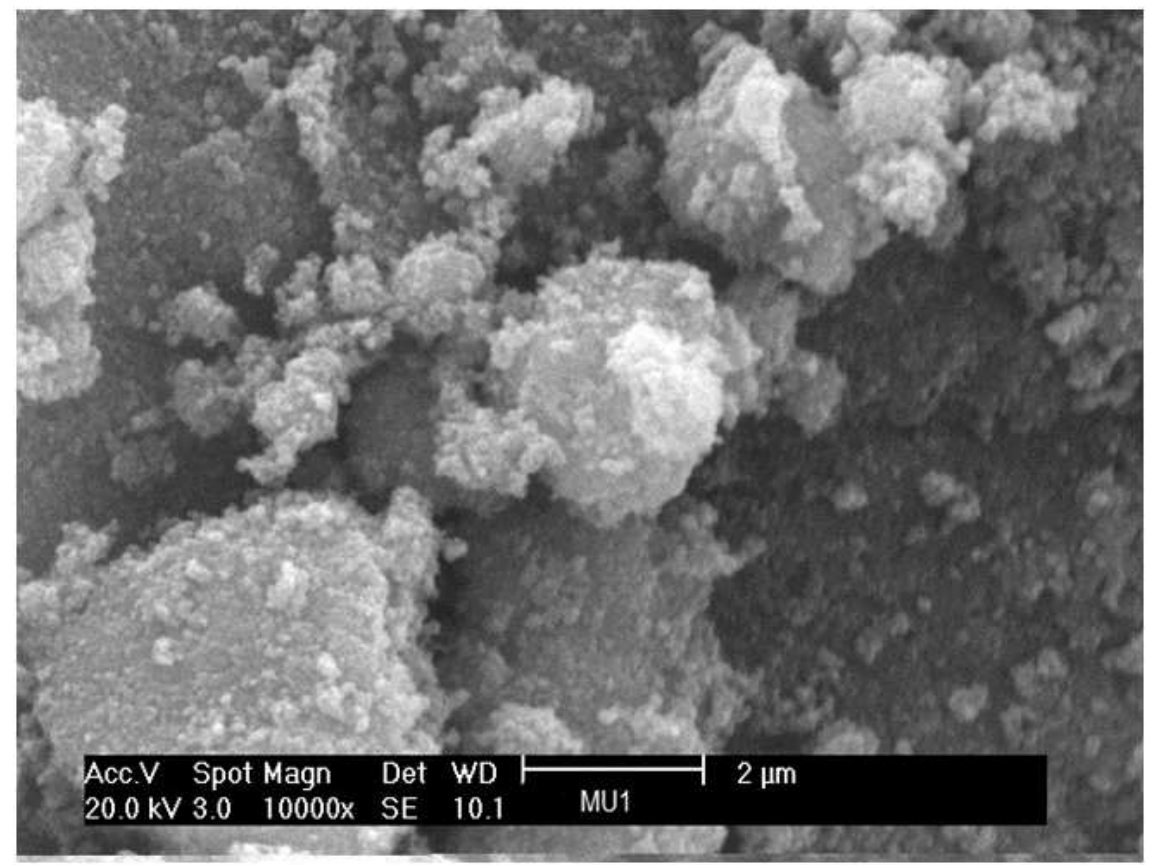

FIGURA 22 - Imagem de MEV de partículas de MU1. Ampliação 10.000x.

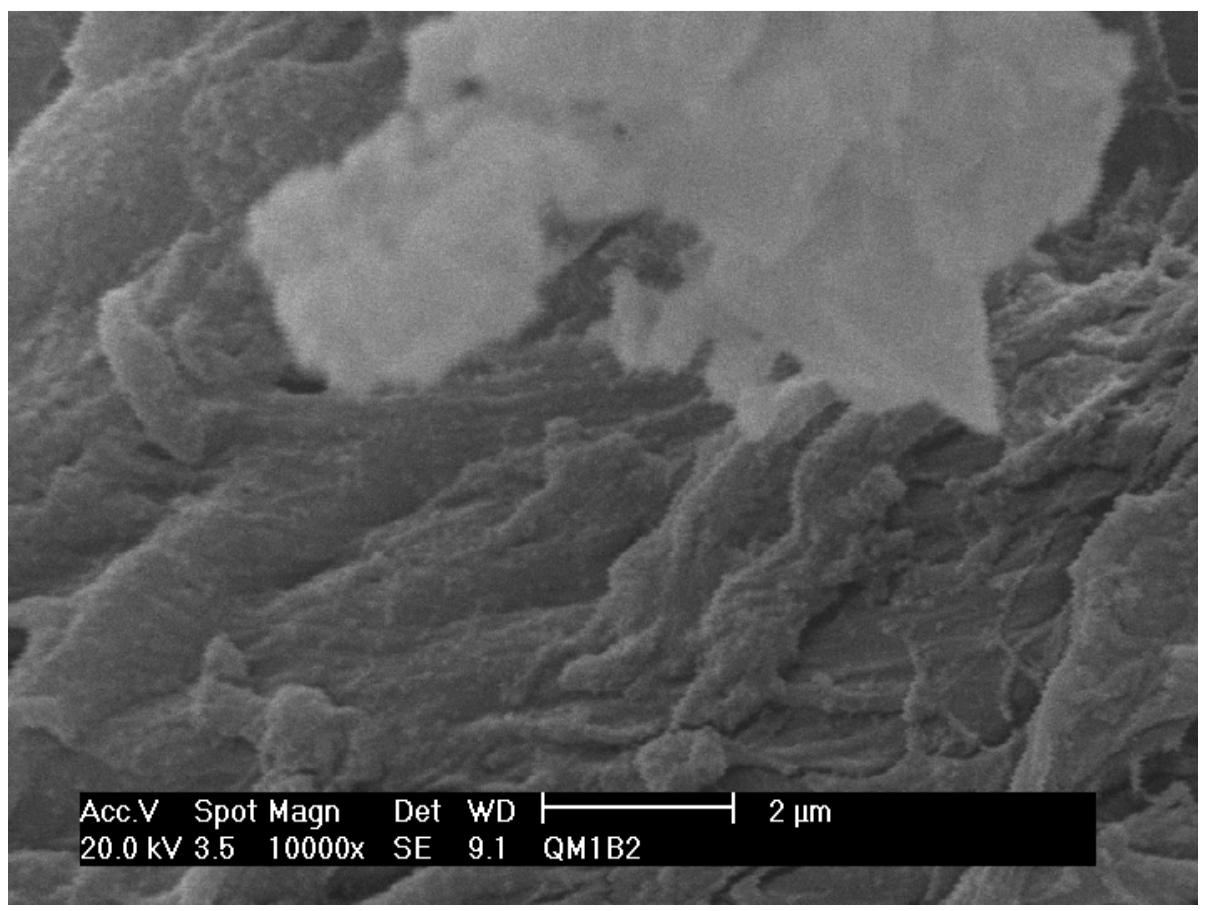

FIGURA 23 - Imagem de MEV de partículas de quitosana magnéticas QM1. Ampliação 10.000x. 


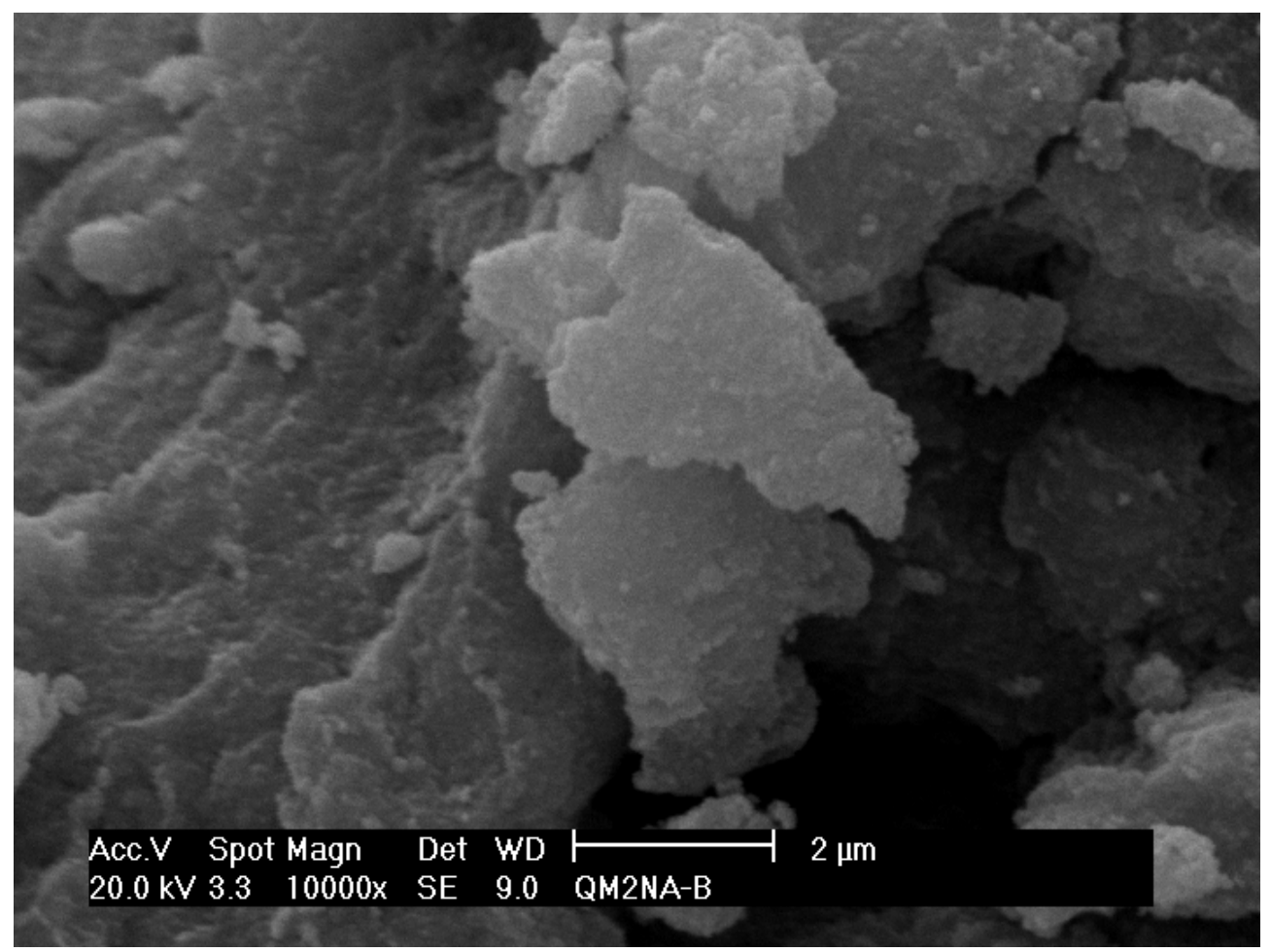

FIGURA 24 - Imagem de MEV de partículas de quitosana magnéticas QM2Na (quitosana reprecipitada com $\mathrm{NaOH}$ ). Ampliação 10.000x.

\section{V.2. Difratometria de raios $X(D R X)$}

\section{V.2.1. Quitosana}

O filme obtido por secagem da solução de quitosana dissolvida em ácido acético foi analisada por DRX. A FIG. 25 ilustra o DRX do filme de quitosana. A quitosana é composta pelas unidades monoméricas 2-amino-2desoxi-D-glicose e, em menor quantidade, 2-acetamida-2-desoxi-D-glicose, possuindo composição variável devido ao grau residual de desacetilação, unidas por ligações glicosídicas $\beta-(1 \rightarrow 4)$ [ARANAZ, 2009].

O polissacarídeo no estado sólido apresenta estrutura semicristalina cujo índice de cristalinidade varia com o grau de desacetilação (GD), peso molecular e preparação de quitosana. A análise de DRX dos pós de quitosana de GD entre 83 e 95\% apresentou menor índice de cristalinidade quanto maior o GD [ANTONINO, 2007]. Entretanto, filmes de quitosana com DA de 84 a 100\% e diferente peso molecular (viscosidade entre 1720 e 11600), obtidos por dissolução e reprecipitação com $\mathrm{NaOH}$, apresentaram estrutura molecular amorfa sem 


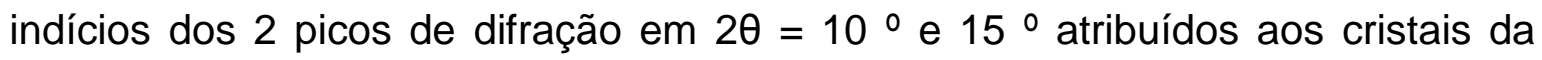
forma hidratada e da forma anidra, respectivamente [OGAWA, 1991]. Filme de quitosana com GD $100 \%$ e peso molecular alto (viscosidade 8500 ), obtido por dissolução com ácido acético e reprecipitado com $\mathrm{NaOH}$, mostrou intensidades

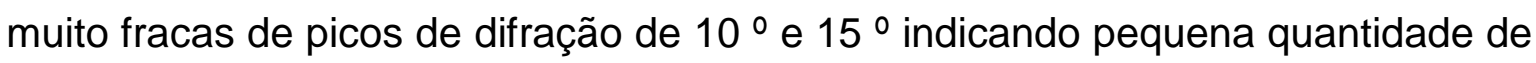
cristais hidratado e anidro com predominância da fase amorfa [OGAWA et al., 1992]. Filme de quitosana com GD $100 \%$ e baixo peso molecular (viscosidade 660) apresentou poucos cristais hidratados (10 ) e maior quantidade de cristais anidros (15 9) e, portanto, com aumento de cristalinidade. DHANIKULA e PANCHAGNULA, 2004 mostraram um filme de quitosana de GD $\geq 85 \%$ com dois picos de difração de baixa intensidade em 19,1 ำ e 23,3ำ sobrepostos no intenso halo de difração indicando a predominância da fase amorfa. $O$ halo amorfo estendeu de $7^{\circ}$ a $45^{\circ} \stackrel{\mathrm{em}}{20}$.

O difratograma do filme de quitosana, ilustrado na FIG. 21, mostra um extenso halo amorfo entre $10 \cong$ e $35 \cong$ de difração e de alta intensidade

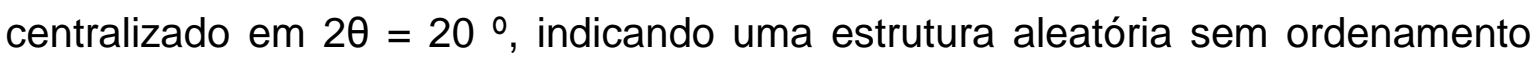
cristalino da base polimérica de quitosana unidas por ligações $N$-glicosídicas. Não há evidências de regiões cristalinas. A alta intensidade do halo sugere uma quantidade maior de parte amorfa.

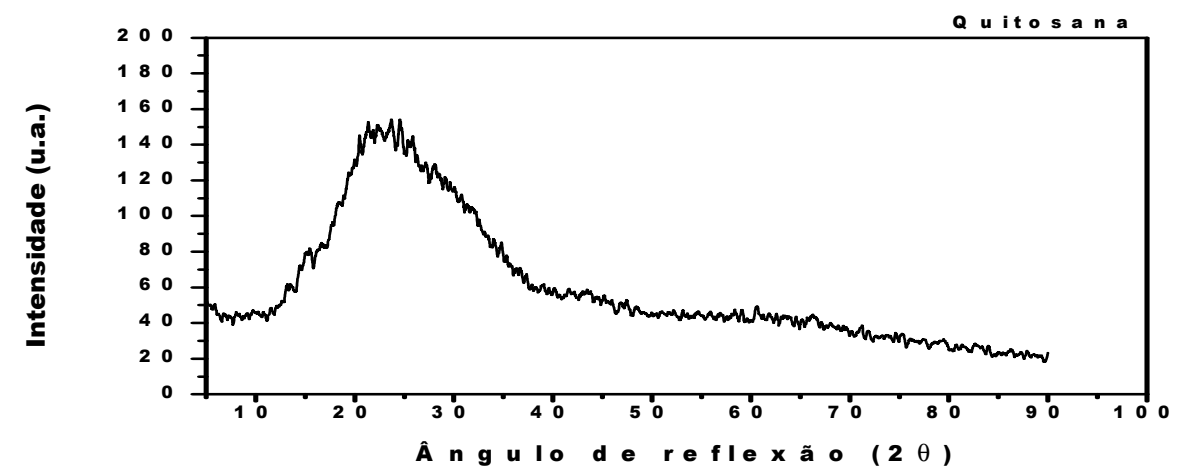

FIGURA 25 - Difratograma de raios $x$ do filme de quitosana.

$$
\text { u.a. }=\text { unidade arbitrária }
$$




\section{V.2.2. Partículas magnéticas de magnetita $\left(\mathrm{Fe}_{3} \mathrm{O}_{4}\right)$ (MU1)}

A FIG. 26 ilustra o difratograma do pó preto MU1 obtido como sendo a magnetita. De acordo com o difratograma padrão de magnetita JCPDS-ICDD 19629 [JCPDS, Diffraction Data Base, ICDD 19-629], os picos de reflexão comprovam a obtenção da magnetita de estrutura cristalina cúbica de face centrada (CFC) do tipo espinélio invertido. Os picos definidos e alargados observados na MU1 são característicos de cristais de nanopartículas. Aplicou-se a equação de Scherrer a fim de estimar o tamanho do cristalito.

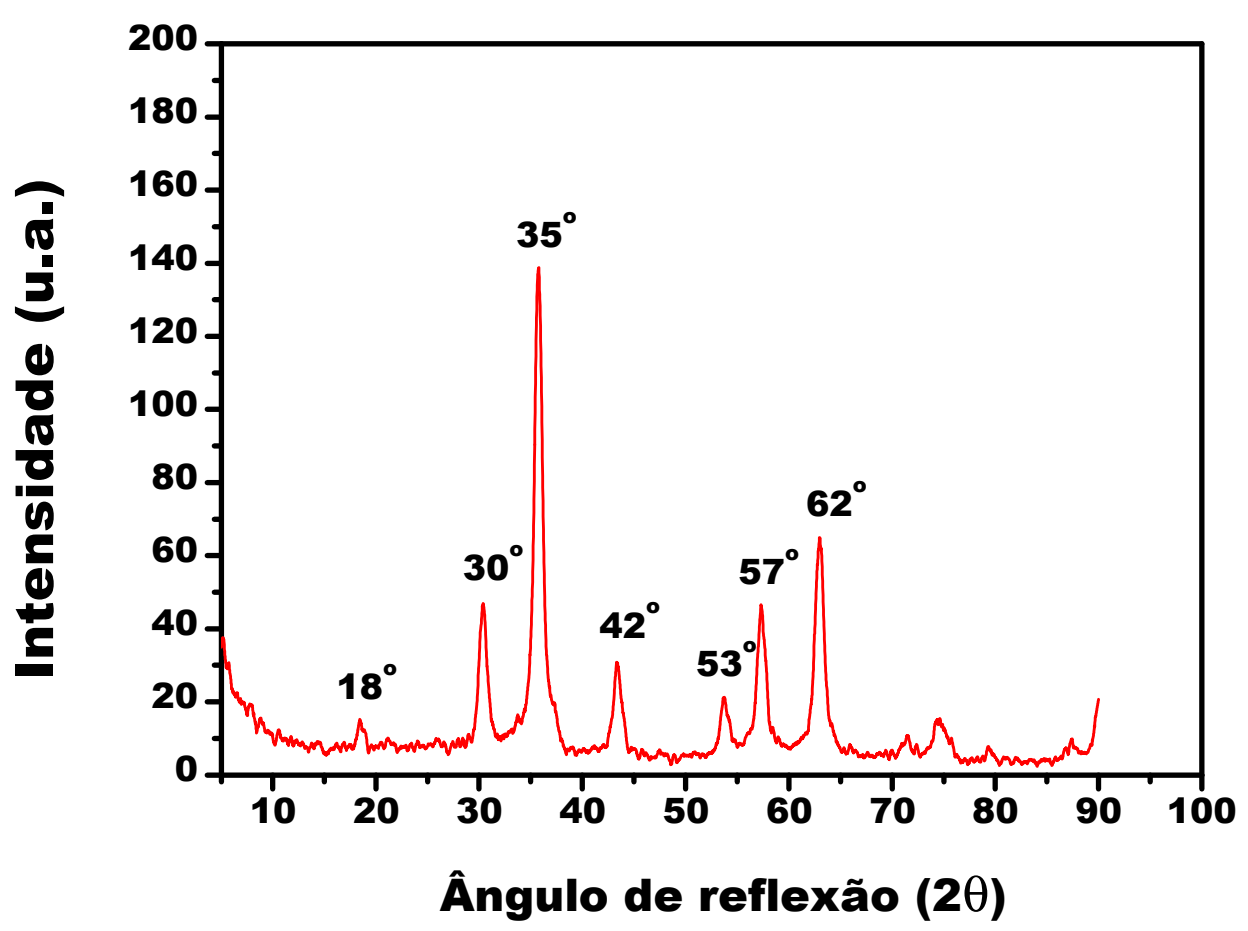

FIGURA 26 - Difratograma de raios X do pó MU1. u.a. = unidade arbitrária 


\section{V.2.3. Quitosana magnética QM1 e QM2Na}

Na FIG. 27 foram sobrepostos os difratogramas da QM1 e QM2Na, cujos picos de reflexão da magnetita foram observados. Os picos são definidos e alargados, ou seja, a magnetita manteve a característica de nanoparticulado. Embora a presença do halo de difração da fase amorfa de quitosana não seja evidente, comparando-se com o difratograma de MU1 (FIG. 26), observou-se que a intensidade dos picos é menor na QM1 e na QM2Na como mostra a TAB. 9. Sugere-se que a diminuição na intensidade dos picos seja causada pela presença da massa de biopolímero e consequentemente menos massa de MU1 para o mesmo volume de amostras analisadas. Além disso, a quitosana absorve parte da radiação, fato que contribui para a atenuação da intensidade dos picos de MU1. Diante dessas evidências, pode-se sugerir que a QM1 e QM2Na sejam compósitos formados por quitosana e nanoparticulas de magnetita.

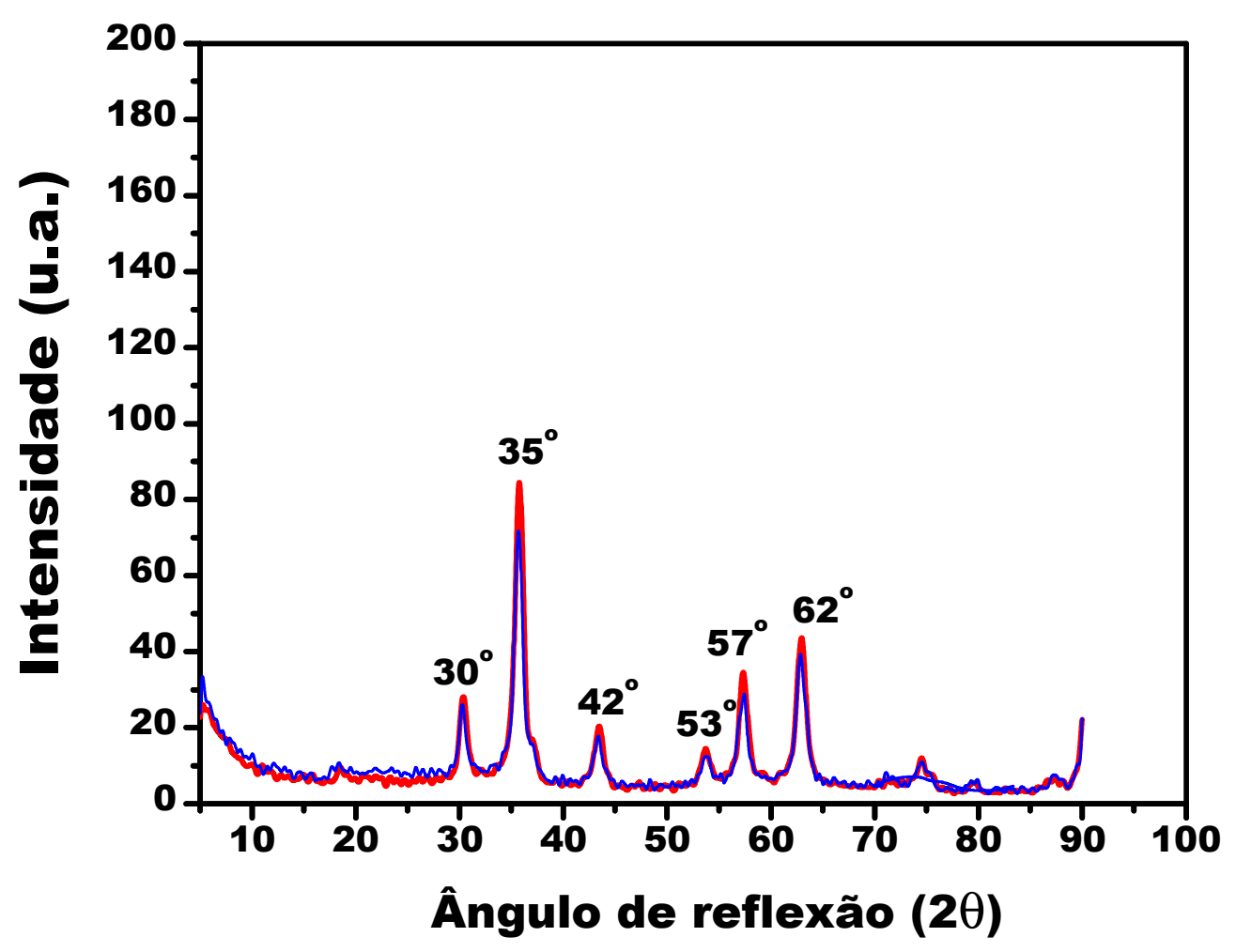

FIGURA 27 - Difratogramas de raios X dos compósitos QM1 e QM2Na sobrepostos. 


\section{V.2.4. Tamanho médio dos cristalitos}

O diâmetro médio dos cristalitos foi calculado aplicando-se a equação de Scherrer, tendo como base a largura à meia altura do pico de difração de

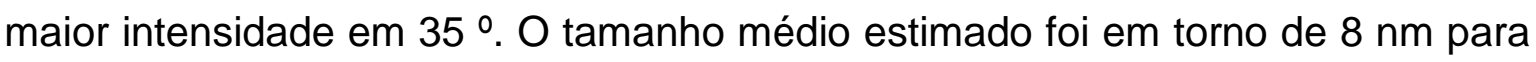
as 3 amostras ensaiadas conforme mostra a TAB. 7.

TABELA 7 - Valores de intensidade dos picos de DRX e diâmetro médio (d) da amostras MU1, QM1 e QM2Na.

\begin{tabular}{cccc}
\hline Amostra & Pico $\left({ }^{\circ}\right)$ & Intensidade (u.a.) & $\mathbf{d}(\mathbf{n m})$ \\
\hline MU1 & 35 & 137 & 8,1 \\
QM1 & 35 & 85 & 7,9 \\
QM2Na & 35 & 72 & 7,9 \\
\hline
\end{tabular}




\section{V.3. Magnetometria de amostra vibrante (MAV)}

As curvas de magnetização foram obtidas a fim de confirmar o comportamento superparamagnético das nanopartículas de MU1. Na FIG. 28a observam-se as curvas de magnetização com alto valor de magnetização de saturação, detalhada na TAB. 8. Entretanto, devido aos fenômenos de anisotropia, as nanopartículas de magnetita da MU1 apresentaram valores de magnetização de saturação menores que da magnetita natural, o qual é $92 \mathrm{emu}^{-1} \mathrm{~g}^{-1}$ [CULLITY, GRAHAM, 2009].
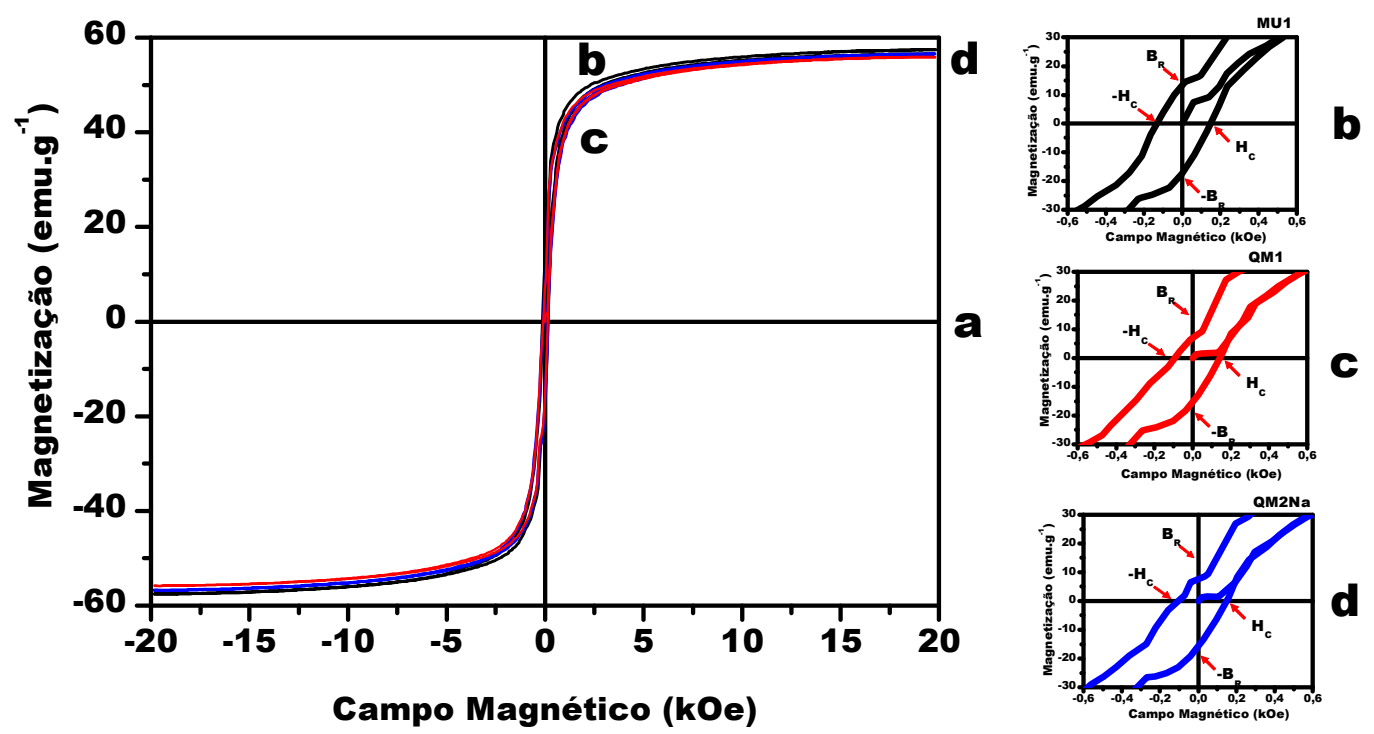

FIGURA 28 - Curvas de magnetização de saturação sobrepostas das MU1, QM1 e QM2Na (a);

Ampliação da região central das curvas de magnetização: MU1 (b),

QM1 (c) e QM2Na (d).

Temperatura de $27 \stackrel{\circ}{\mathrm{C}}$.

TABELA 8 - Valores de magnetização das partículas de MU1, QM1 e QM2Na.

\begin{tabular}{cc}
\hline Amostra & $\begin{array}{c}\text { Magnetização de saturação } \\
\text { (emu. } \text { - }^{-1} \text { ) }\end{array}$ \\
\hline MU1 & 56,6 \\
QM1 & 55,9 \\
QM2Na & 56,1 \\
\hline
\end{tabular}


De acordo com os resultados apresentados na TAB. 8 nota-se que os valores estão bem próximos para as 3 amostras ensaiadas, indicando que a presença da quitosana nos compósitos não foi suficiente para causar alteração significativa na magnetização de saturação.

Nota-se que todas as nanopartículas apresentaram um mínimo de histerese, caracterizada pelo atraso entre o campo magnético aplicado e a magnetização do material (densidade de fluxo) (FIG. 28b. 28c, 28d e TAB. 9 [LATHAM, WILLIAMS, 2008; ZHAO et al., 2009].

TABELA 9 - Valores de magnetização das nanopartículas de MU1 e dos compósitos QM1 e QM2Na.

\begin{tabular}{ccccc}
\hline Amostra & $\begin{array}{c}+\mathbf{B}_{\mathrm{R}} \\
\left(\mathbf{e m u . \mathbf { g } ^ { - 1 } )}\right.\end{array}$ & $\begin{array}{c}-\mathrm{H}_{\mathrm{C}} \\
(\mathbf{k O e})\end{array}$ & $\begin{array}{c}-\mathbf{B}_{\mathrm{R}} \\
\left(\mathbf{e m u . \mathbf { g } ^ { - 1 }}\right)\end{array}$ & $\begin{array}{c}+\mathrm{H}_{\mathrm{C}} \\
(\mathbf{k O e})\end{array}$ \\
\hline MU1 & 14 & 0,14 & 17 & 0,15 \\
QM1 & 7 & 0,10 & 15 & 0,15 \\
QM2Na & 6 & 0,09 & 14 & 0,14 \\
\hline \multicolumn{5}{c}{$\mathbf{B}_{\mathrm{R}} \rightarrow$ densidade de fluxo remanente } \\
& $\mathrm{H}_{\mathrm{C}} \rightarrow$ campo coercivo & &
\end{tabular}

A retenção de magnetização ocorreu, provavelmente, devido à aglomeração dos grãos, formando camadas de superfícies irregulares, alterando a sua dimensão, mudando drasticamente a direção do campo magnético (anisotropia magnética), e afetando, dessa forma, o fenômeno monodomínio [MAHMOUDI et al., 2009].

\section{V.4. Calorimetria exploratória diferencial (DSC)}

Os ensaios de DSC foram realizados com o intuito de caracterizar partículas magnéticas de magnetita, confirmar o revestimento com a quitosana e ressaltar alguma alteração relevante. Na sobreposição apresentada na FIG. 29 e detalhada na TAB. 10 é possível observar o comportamento individual de cada material, bem como a interação do biopolímero com as partículas magnéticas. 


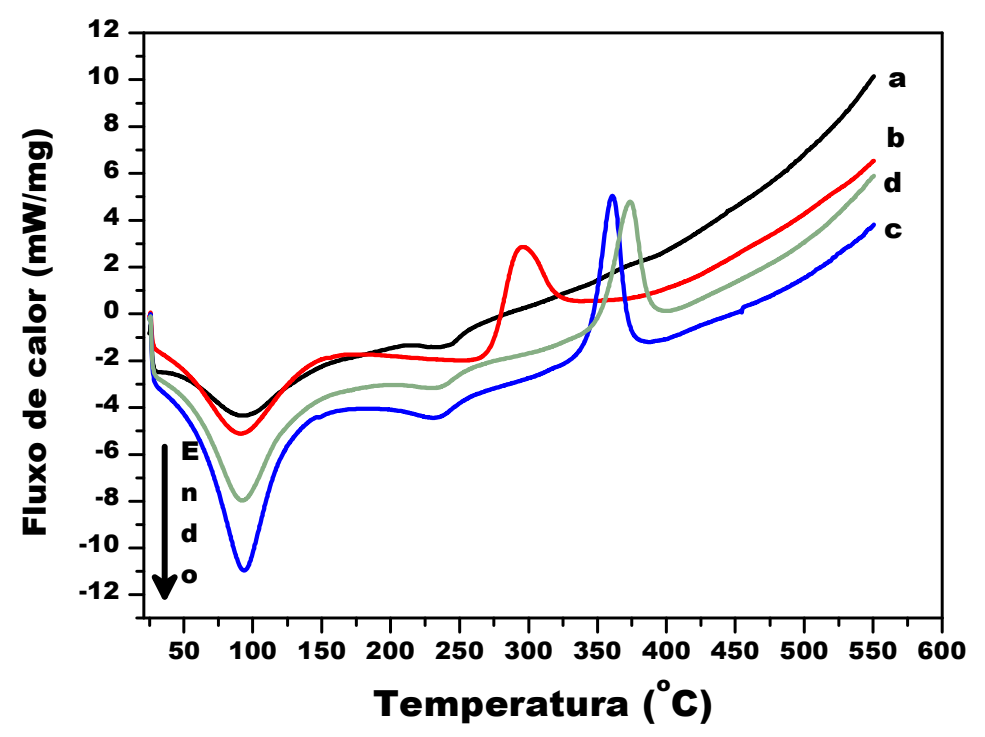

FIGURA 29 - Curvas DSC das amostras: MU1 (a); filme de quitosana (b); QM1 (c); QM2Na (d). $10^{\circ} \mathrm{C} \cdot \mathrm{min}^{-1}, 50 \mathrm{~mL} \cdot \mathrm{min}^{-1}, \mathrm{~N}_{2}$.

TABELA 10 - Transições térmicas do filme de quitosana, das partículas magnéticas MU1 e dos compósitos QM1 e QM2Na.

\begin{tabular}{|c|c|c|c|c|c|c|c|}
\hline \multirow[t]{2}{*}{ Identificação } & \multicolumn{5}{|c|}{ Endotérmico $\left({ }^{\circ} \mathrm{C}\right)$} & \multicolumn{2}{|c|}{ Exotérmico $\left({ }^{\circ} \mathrm{C}\right)$} \\
\hline & $\begin{array}{c}\text { Massa } \\
(\mathrm{mg})\end{array}$ & $\begin{array}{l}T p_{1} \\
\left({ }^{\circ} C\right)\end{array}$ & $\begin{array}{c}\Delta H_{1} \\
\left(m J \cdot m g^{-1}\right)\end{array}$ & $\begin{array}{l}T p_{2} \\
\left({ }^{\circ} C\right)\end{array}$ & $\begin{array}{c}\Delta H_{2} \\
\left(m J \cdot m g^{-1}\right)\end{array}$ & $\begin{array}{l}T p_{3} \\
\left({ }^{\circ} C\right)\end{array}$ & $\begin{array}{c}\Delta H_{3} \\
\left(m J \cdot m g^{-1}\right)\end{array}$ \\
\hline Quitosana & 3,6 & 91 & 346,7 & $\overline{------}$ & ------- & 295 & 277,0 \\
\hline MU1 & 11,3 & 93 & 91,1 & 241 & 6,9 & ------- & ------- \\
\hline QM1 & 12,2 & 93 & 183,6 & 233 & 10,9 & 361 & 63,3 \\
\hline QM2Na & 11,3 & 92 & 170,7 & 234 & 9,1 & 374 & 62,6 \\
\hline
\end{tabular}

$\mathrm{Na}$ curva DSC da amostra MU1 (FIG. 29a) observam-se dois picos endotérmicos. O primeiro, por volta de $90{ }^{\circ} \mathrm{C}$, corresponde ao processo de desidratação, uma vez que a preparação das amostras foi realizada em meio 
aquoso. O segundo, a $241{ }^{\circ} \mathrm{C}$, se refere à transição de fase, onde a magnetita $\left(\mathrm{Fe}_{3} \mathrm{O}_{4}\right)$ é convertida em outras espécies de óxidos de ferro [PENICHE-COVAS et al., 1993; JUNG et al., 1999].

Na curva DSC da amostra do filme de quitosana (FIG. 29b), notam-se dois picos, um endotérmico, também característico da desidratação do material, e outro exotérmico por volta de $295{ }^{\circ} \mathrm{C}$, que está relacionado ao processo de degradação da quitosana, por meio da desidratação dos anéis sacarídeos, despolimerização e decomposição de unidades acetiladas e desacetiladas do biopolímero [NETO et al, 2005].

Nas curvas DSC das amostras QM1 (FIG. 29c) e QM2Na (FIG. 29d) surgem três picos. O primeiro endotérmico, na região de desidratação $\left(\sim 90{ }^{\circ} \mathrm{C}\right)$, 0 segundo, também endotérmico, em $233{ }^{\circ} \mathrm{C}$ e $234{ }^{\circ} \mathrm{C}$, respectivamente, indicando a presença das partículas de magnetita em processo de transição, e o terceiro, exotérmico em $361{ }^{\circ} \mathrm{C}$ e $374{ }^{\circ} \mathrm{C}$ dando índicios de decomposição térmica do biomaterial.

A elevação na temperatura de decomposição térmica em relação ao biopolímero, da ordem de $66^{\circ} \mathrm{C}$ para $\mathrm{QM} 1$ e $79{ }^{\circ} \mathrm{C}$ para $\mathrm{QM} 2 \mathrm{Na}$, supõe a presença de ligações covalentes entre a quitosana e o Fe. Entre os compósitos, o QM2Na submetido à precipitação com hidróxido de sódio apresentou maior estabilidade térmica decompondo-se em temperatura mais alta. Esse deslocamento é o indicativo de um biomaterial com maior estabilidade térmica, ocasionada, provavelmente pelo tratamento de precipitação com $\mathrm{NaOH}$. As curvas DSC confirmaram a formação do compósito pela ocorrência desses eventos endotérmicos e exotérmicos.

\section{V.5. Termogravimetria (TG)}

Na FIG. 30 e TAB. 11 referentes às curvas TG e DTG da quitosana, observam-se dois estágios de perda de massa. O primeiro, com pico máximo (DTG) em $61{ }^{\circ} \mathrm{C}$ e perda de massa de $12,70 \%$, está associado ao processo de desidratação do material. O segundo tem um pico máximo (DTG) em $288{ }^{\circ} \mathrm{C}$, perda de massa de 50,80\%, e está relacionado ao processo de desidratação dos anéis sacarídeos, despolimerização e decomposição de unidades acetiladas e desacetiladas do biopolímero. 


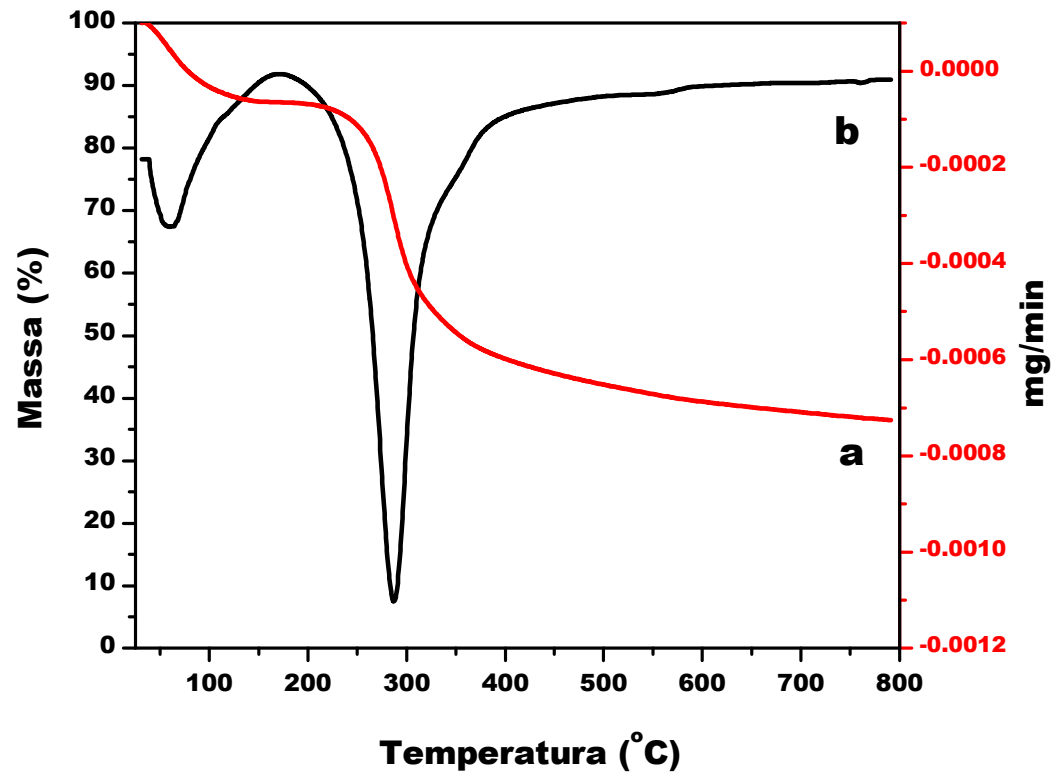

FIGURA 30 - Curvas de TG (a) e DTG (b) do filme de quitosana. 10ำ. $\mathrm{min}^{-1}$, $50 \mathrm{~mL} \cdot \mathrm{min}^{-1}, \mathrm{~N}_{2}$.

TABELA 11 - Caracterização por TG e DTG da quitosana, do pó de magnetita MU1e dos compósitos QM1 e QM2Na.

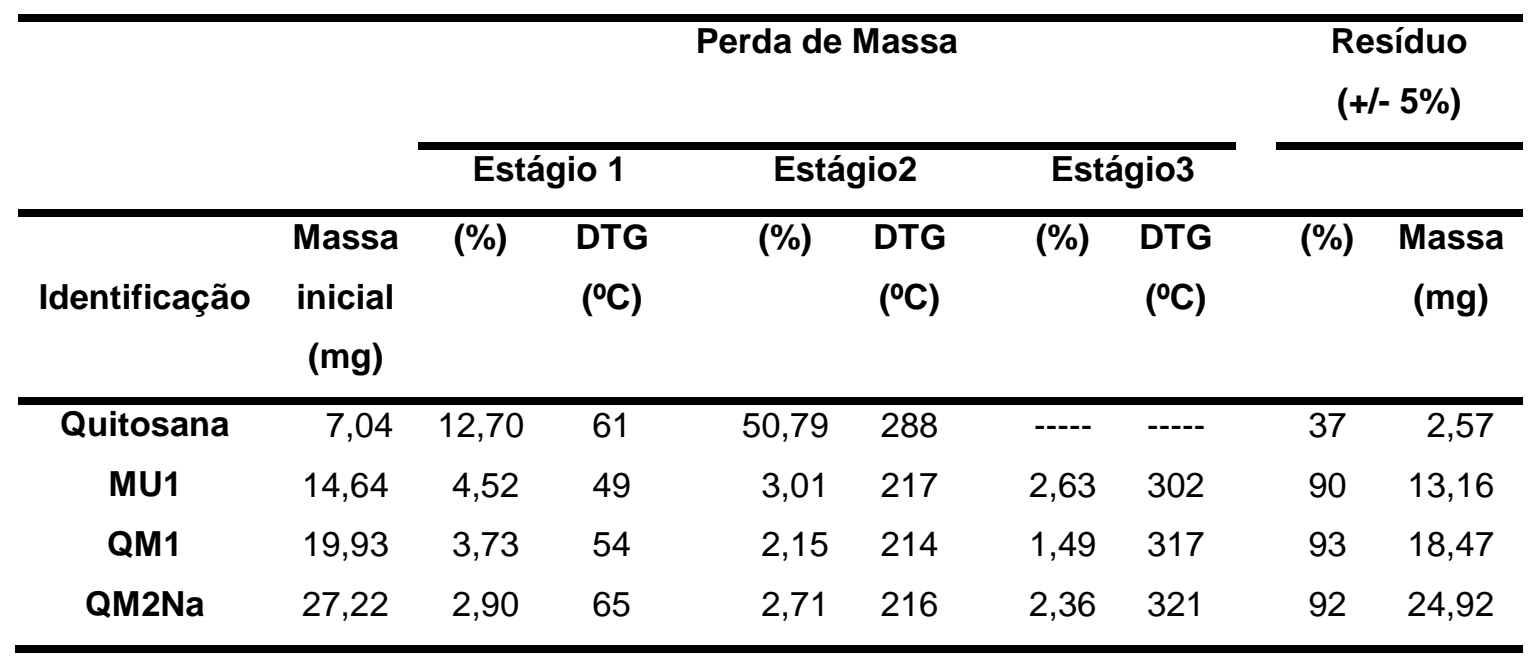


Devido à lenta taxa de decomposição da cadeia polimérica associada à realização dos experimentos em ambiente inerte, sob atmosfera de nitrogênio $\left(\mathrm{N}_{2}\right)$, constatou-se um resíduo de carbono de aproximadamente 37\% (TAB. 11), mesmo com material sendo ensaiado até $800^{\circ} \mathrm{C}$ [PENICHE-COVAS et al., 1993; TONHI, PLEPIS, 2002].

Para a magnetita MU1, observou-se a ocorrência de três eventos térmicos como mostram as FIG. 31a e TAB. 11. O primeiro, referente à liberação de água superficial, inicia-se por volta de $30^{\circ} \mathrm{C}$ e se completa ao redor de $130{ }^{\circ} \mathrm{C}$ com um pico máximo em torno de $49 \stackrel{\circ}{\circ}$ e perda de massa em torno de $4,52 \%$. $\mathrm{O}$ segundo, com temperatura de pico em $217^{\circ} \mathrm{C}$ e com perda de massa de $3 \%$. E o terceiro, mais largo e menos definido que o segundo, com temperatura de pico em $302{ }^{\circ} \mathrm{C}$ e perda de massa em torno de $2 \%$. Supõe-se que os dois últimos eventos tenham ocorrido devido à decomposição da magnetita em outras espécies de óxidos de ferro [SHAN et al., 2007; ZHAO et al., 2006].

As curvas de QM1 e QM2Na representadas pelas FIG. 31b e 31c, respectivamente, tiveram o comportamento análogo ao dos eventos ocorridos para MU1.

A primeira decomposição térmica para QM1 e QM2Na apresentou um pico máximo (DTG) de $54^{\circ} \mathrm{C}$ e $65^{\circ} \mathrm{C}$, associada a uma perda de massa de $3,73 \%$ e $2,90 \%$, respectivamente. Isso pode estar relacionado ao fato de a quitosana agregada às nanopartículas ser extremamente hidrofílica, retendo mais água em sua estrutura, necessitando de maior quantidade de energia térmica para a liberação dessas moléculas de sua superfície [GUO et al., 2010].

Outro fator relevante é que, para QM2Na, a temperatura de pico $\left(65^{\circ} \mathrm{C}\right)$ foi maior que a alcançada pela quitosana $\left(61^{\circ} \mathrm{C}\right)$, ou seja, o hidróxido de sódio, além de precipitar o polímero, melhorou sua interação com os íons metálicos, contribuindo para a elevação da temperatura durante o processo de desidratação.

O segundo pico em $214^{\circ} \mathrm{C}(\mathrm{QM} 1)$ e $216^{\circ} \mathrm{C}(\mathrm{QM} 2 \mathrm{Na})$, assim como para MU1, provavelmente está ligado à decomposição dos hidróxidos de ferro, seguido pela formação dos óxidos de ferro [GUO et al., 2010].

$\mathrm{O}$ terceiro pico identificado nesse ensaio, em $317^{\circ} \mathrm{C}$ e $321^{\circ} \mathrm{C}$, mais bem definido nos compósitos que na magnetita, apresenta temperatura próxima à do segundo evento ocorrido para a quitosana $\left(288^{\circ} \mathrm{C}\right)$, podendo sugerir que ele está relacionado à decomposição da camada de cobertura das partículas magnéticas. 
O efeitos causados pela reação do polímero com o $\mathrm{NaOH}$ também é percebido nessa fase, uma vez que há um sensível deslocamento do pico para uma temperatura mais alta indicando uma estrutura com maior estabilidade térmica.

A magnetita e os compósitos magnéticos, contendo partículas de magnetita, apresentaram massa residual de $90 \%$, 93\% e 92\%, respectivamente, até a temperatura de $800^{\circ} \mathrm{C}$ (TAB. 12). Essa diferença no porcentual de resíduo, embora seja pequena, revela a presença da quitosana ligada às partículas de magnetita.

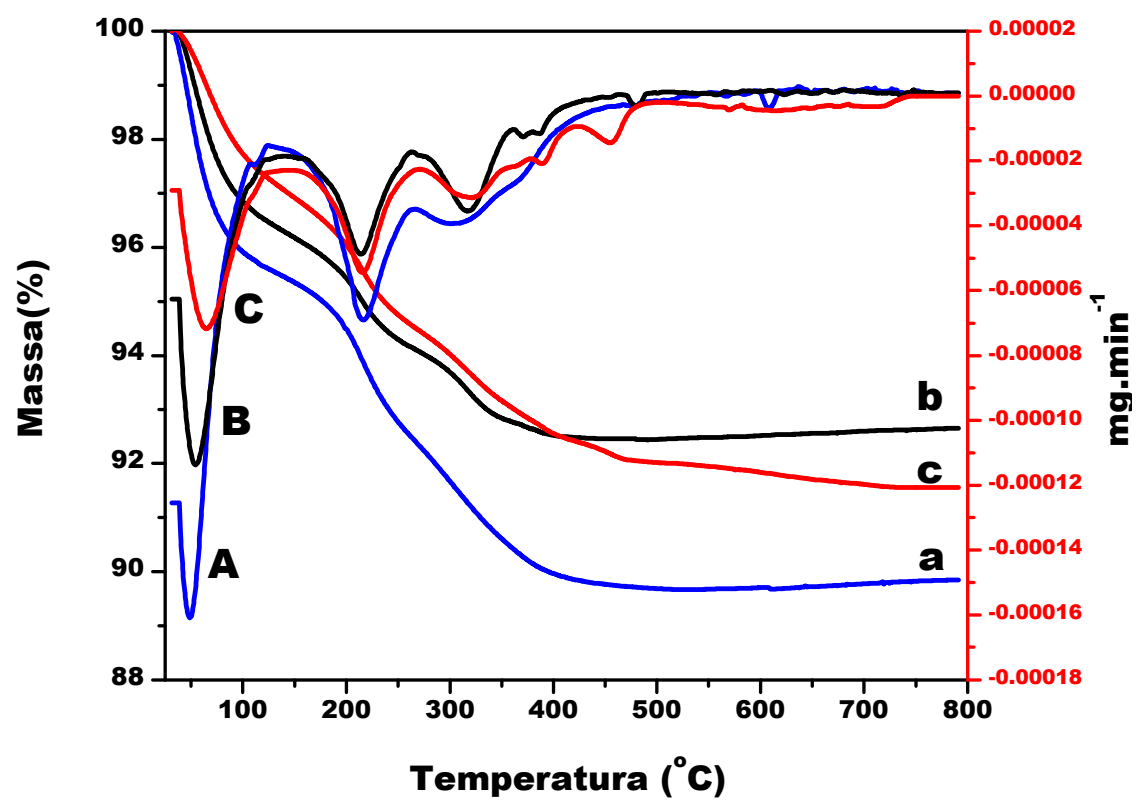

FIGURA 31 - Curvas de TG (a, b, c) e DTG (A, B, C) de MU1 (a, A), QMU1 (b, B) e QM2Na (c, C). $10^{\circ} \mathrm{C} \cdot \mathrm{min}^{-1}, 50 \mathrm{~mL} \cdot \mathrm{min}^{-1}, \mathrm{~N}_{2}$. 
TABELA 12- Massas residuais da MU1 e dos compósitos QM1 e QM2Na ensaiadas por meio de TG.

\begin{tabular}{cccc}
\hline \multirow{2}{*}{ Identificação } & Descrição & $\begin{array}{c}\text { Perda de } \\
\text { massa } \\
(\%)\end{array}$ & $\begin{array}{c}\text { Resíduo } \\
(\%)\end{array}$ \\
\hline MU1 & Magnetita & 10,16 & 90 \\
QM1 & Magnetita revestida com quitosana & 7,37 & 93 \\
\multirow{2}{*}{ QM2Na } & $\begin{array}{c}\text { Magnetita revestida com quitosana } \\
\text { e solidificada com } \mathrm{NaOH}\end{array}$ & 8,44 & 92 \\
\hline
\end{tabular}

V.6. Espectroscopia de absorção na região do Infravermelho por transformada de Fourier (FTIR)

As principais bandas de absorção observadas no espectro infravermelho (FIG. 32) da quitosana, da MU1, QM1 e QM2Na estão resumidas na TAB. 13.

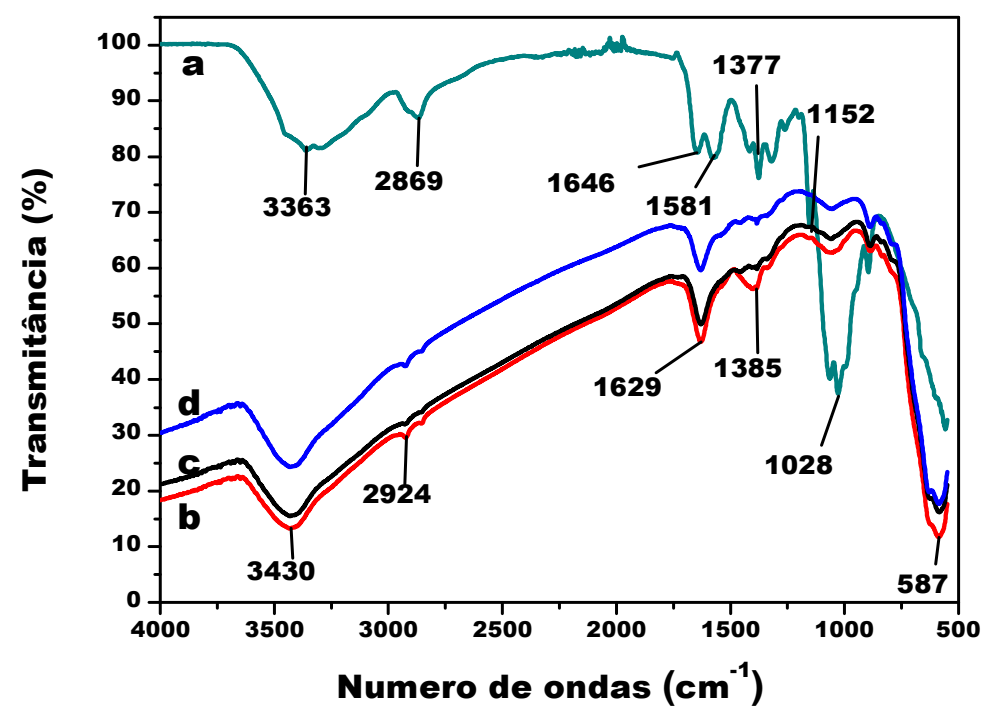

FIGURA 32 - Espectro de absorção na região do infravermelho: (a) filme de quitosana ensaiado por técnica de reflexão (ATR); e partículas magnéticas MU1 (b); QM1 (c) e QM2Na (d), diluídas em KBr . 
TABELA 13 - Principais atribuições de bandas de absorção de infravermelho e frequências vibracionais para a quitosana, MU1, QM1 e QM2Na.

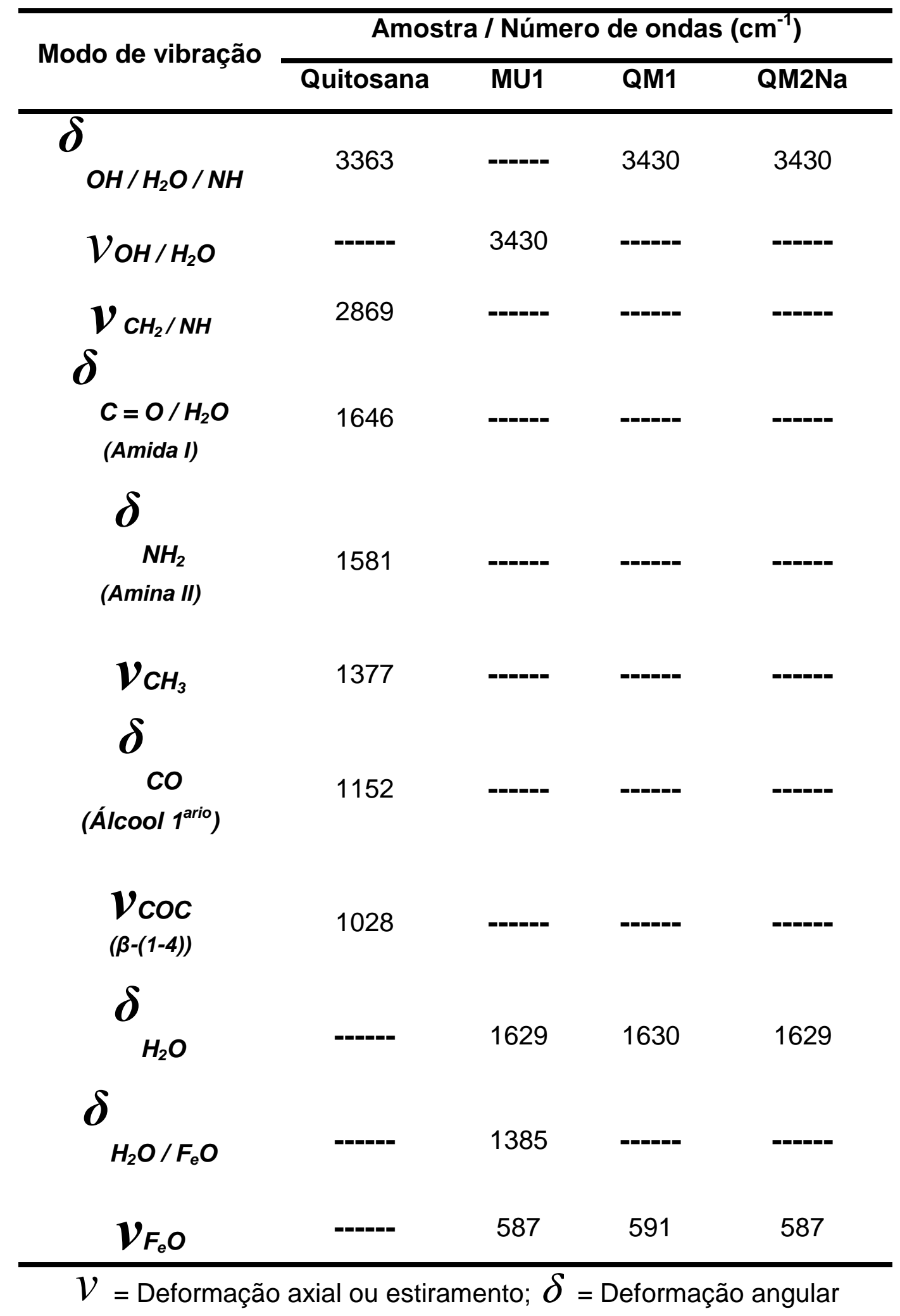


No ensaio com a quitosana, a banda de deformação axial $\mathrm{OH}$ absorve no intervalo entre $3672 \mathrm{~cm}^{-1}$ e $3008 \mathrm{~cm}^{-1}$, apresentando uma banda de absorção ao redor de $3363 \mathrm{~cm}^{-1}$ e se sobrepõe à banda de estiramento axial $\mathrm{NH}$, que vibraria próximo a $3335 \mathrm{~cm}^{-1}$. As vibrações em $2869 \mathrm{~cm}^{-1}$ e $1377 \mathrm{~cm}^{-1}$ se referem ao estiramento de $\mathrm{CH}_{2}$ e $\mathrm{CH}_{3}$. A absorção na região de $1646 \mathrm{~cm}^{-1}$ está associada ao grupo carbonila $(\mathrm{C}=\mathrm{O})$ da amida I que diminui de acordo com o aumento do grau de desacetilação [SUGIMOTO et al., 1998].

Em $1581 \mathrm{~cm}^{-1}$ observa-se a deformação angular $\mathrm{NH}_{2}$ (amida II). Em $1152 \mathrm{~cm}^{-1}$ há a ocorrência da banda de absorção de estiramento vibracional CO do álcool primário. $\mathrm{E}$ em $1028 \mathrm{~cm}^{-1}$ encontra-se a banda de estiramento assimétrico na região COC referente à ligação glicosídica $\beta$-(1-4) [SUGIMOTO et al., 1998].

Notam-se as bandas de absorção em $3430 \mathrm{~cm}^{-1}, 1629 \mathrm{~cm}^{-1}$ e $1385 \mathrm{~cm}^{-1}$ que são relativas às vibrações do grupo $\mathrm{OH}$ e $\mathrm{H}_{2} \mathrm{O}$ (FIG. 32b) [PAWLAK e MUCHA, 2004]. O pico em localizado em $1372 \mathrm{~cm}^{-1}$ e $1385 \mathrm{~cm}^{-1}$ também pode estar relacionado à vibração $\mathrm{CH}\left(\mathrm{CH}_{3}\right)$. A banda ao redor de $587 \mathrm{~cm}^{-1}$ é caracterizada pela ligação (Fe-O) de óxido de ferro que pode ser tanto da magnetita, maghemita ou de outras espécies de óxido de ferro [TURCU et al., 2009; YOO et al., 2007].

Similarmente ao ocorrido com a magnetita, nos compósitos também se observou o aparecimento das bandas de absorção em $3434 \mathrm{~cm}^{-1}, 1630 \mathrm{~cm}^{-1}$, e ao redor de $590 \mathrm{~cm}^{-1}$. Porém, as vibrações em $1385 \mathrm{~cm}^{-1}$ da magnetita e em 1028 $\mathrm{cm}^{-1}$ referente à ligação glicosídica não foram notadas. 


\section{V.7. Ensaios biológicos}

A curva padrão do BSA está ilustrada na FIG. 33. Ela foi obtida por regressão linear com um valor de coeficiente de correlação linear $\left(r^{2}\right)$ igual a 0,99538 , sendo $a=0,00824$ e $b=0,02353$. As concentrações proteicas obtidas dos estudos subsequentes foram determinadas a partir desta curva.

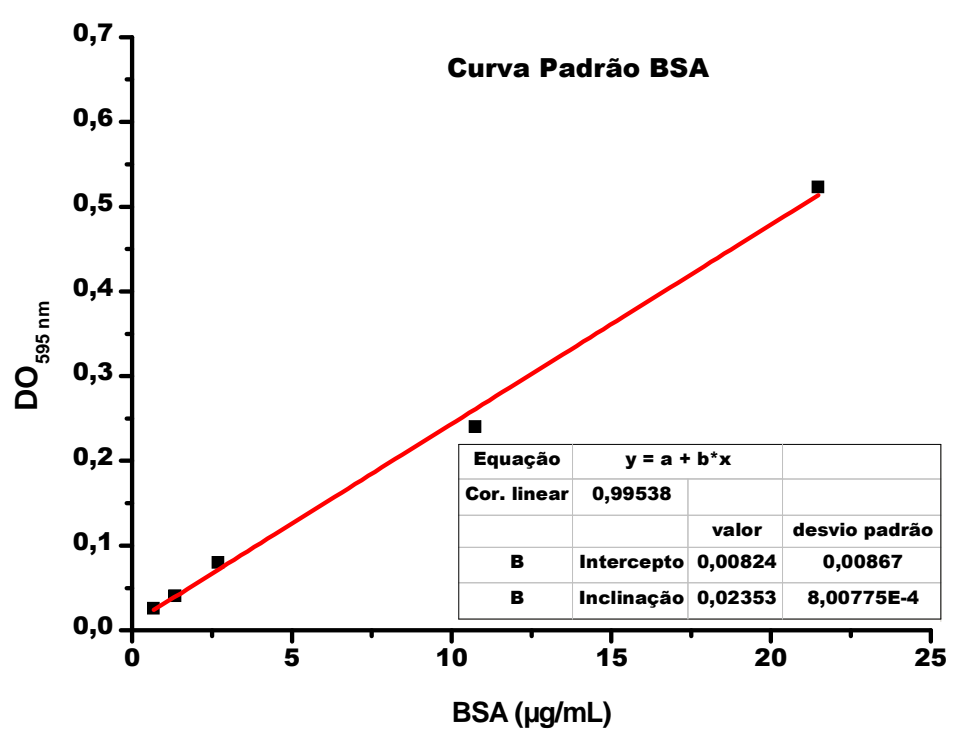

FIGURA 33 - Curva padrão da BSA.

\section{V.7.1. Tempo de incubação das proteínas $\left(2 \mathrm{mg} \cdot \mathrm{mL}^{-1}\right)$ nas partículas magnéticas}

O conteúdo proteico das amostras varia com o tempo de contato com as partículas magnéticas. Os dados estão apresentados em relação à solução inicial de cada proteína colocada em contato com a partícula magnética; foram comparados os diferentes intervalos de tempo para verificar a de melhor rendimento.

\section{V.7.1.1. Albumina de soro bovino (BSA)}

De acordo com a FIG. 34 e TAB. 14, em 30 min de incubação aproximadamente $13 \%$ do BSA (2 mg. $\left.\mathrm{mL}^{-1}\right)$ foram imobilizados nas partículas QM1Glu-BSA e QM2NaGlu-BSA, e 35\% nas QM3Glu-BSA. A quitosana 
magnética reticulada e funcionalizada apresentou melhor resultado de imobilização de SAB. Observaram-se pequenas variações no porcentual de imobilização até o limite de tempo ensaiado de $300 \mathrm{~min}$, porém verificou-se que ocorreu a saturação para a concentração estudada não havendo necessidade de um período maior de incubação.

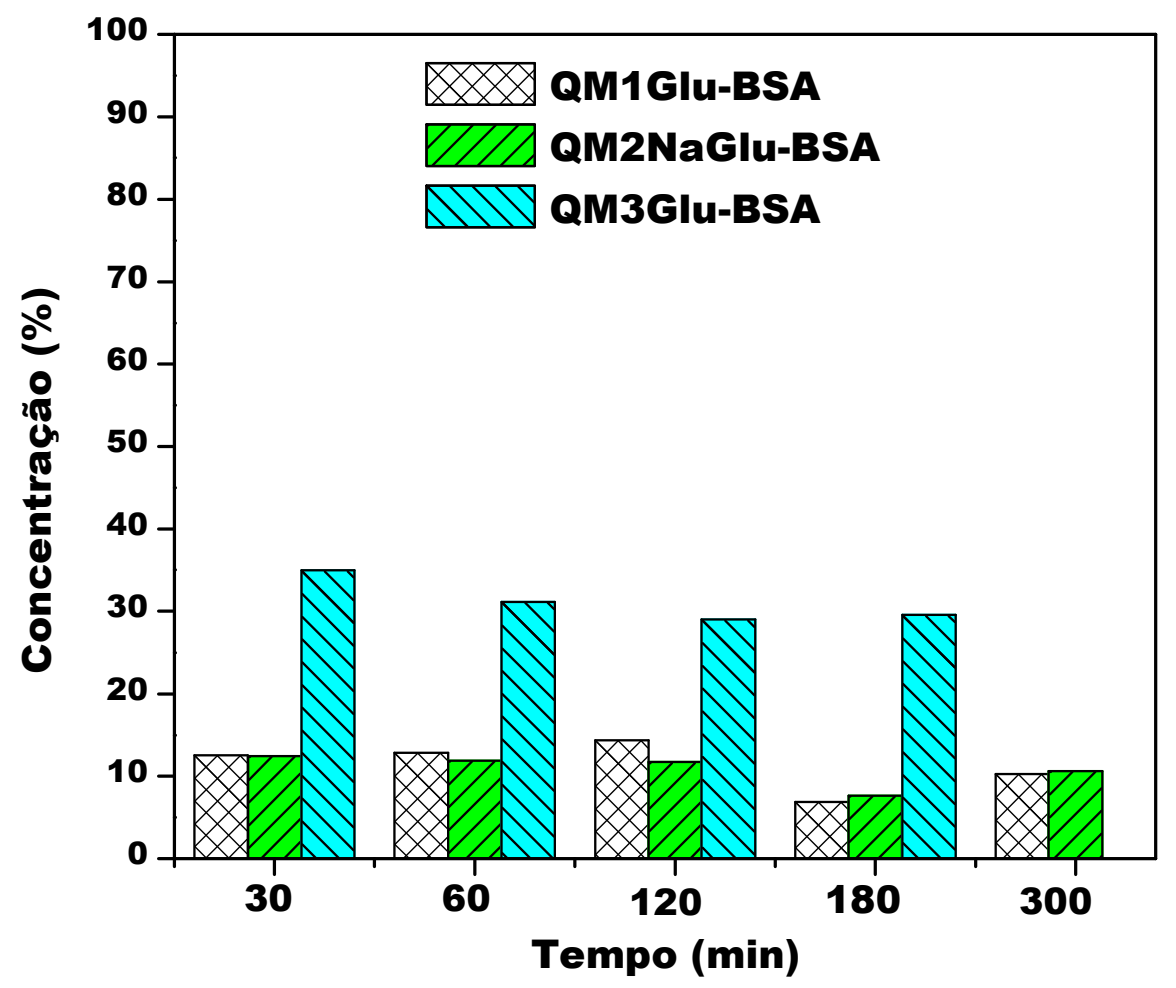

FIGURA 34 - Imobilização do albumina de soro bovino (BSA) nas partículas de quitosana magnéticas.

$[\mathrm{BSA}]=2 \mathrm{mg} \cdot \mathrm{mL}^{-1}$ 
TABELA 14 - Percentual imobilizado com variação de tempo de incubação da BSA nas partículas de quitosana magnéticas.

\begin{tabular}{cccc}
\hline Tempo (min) & QM1Glu-BSA (\%) & QM2NaGlu-BSA (\%) & QM3Glu-BSA (\%) \\
\hline 30 & 13 & 12 & 35 \\
60 & 13 & 12 & 31 \\
120 & 14 & 12 & 29 \\
180 & 7 & 8 & 30 \\
300 & 10 & 11 & $-\cdots$ \\
\hline
\end{tabular}

\section{V.7.1.2. Colágeno}

Conforme mostra a FIG. 35, o porcentual de imobilização do colágeno ocorreu de forma irregular no intervalo de tempo estudado, de $30 \mathrm{~min}$ a $300 \mathrm{~min}$, não apresentando um resultado conclusivo quanto à imobilização. Após a incubação, algumas amostragens não apresentaram reação com o reagente de Bradford impossibilitando a leitura de absorbância no espectrofotômetro. Este fato pode estar associado à dificuldade encontrada na preparação do colágeno e uma possível alteração da proteína em reações secundárias com as partículas magnéticas durante a incubação. 


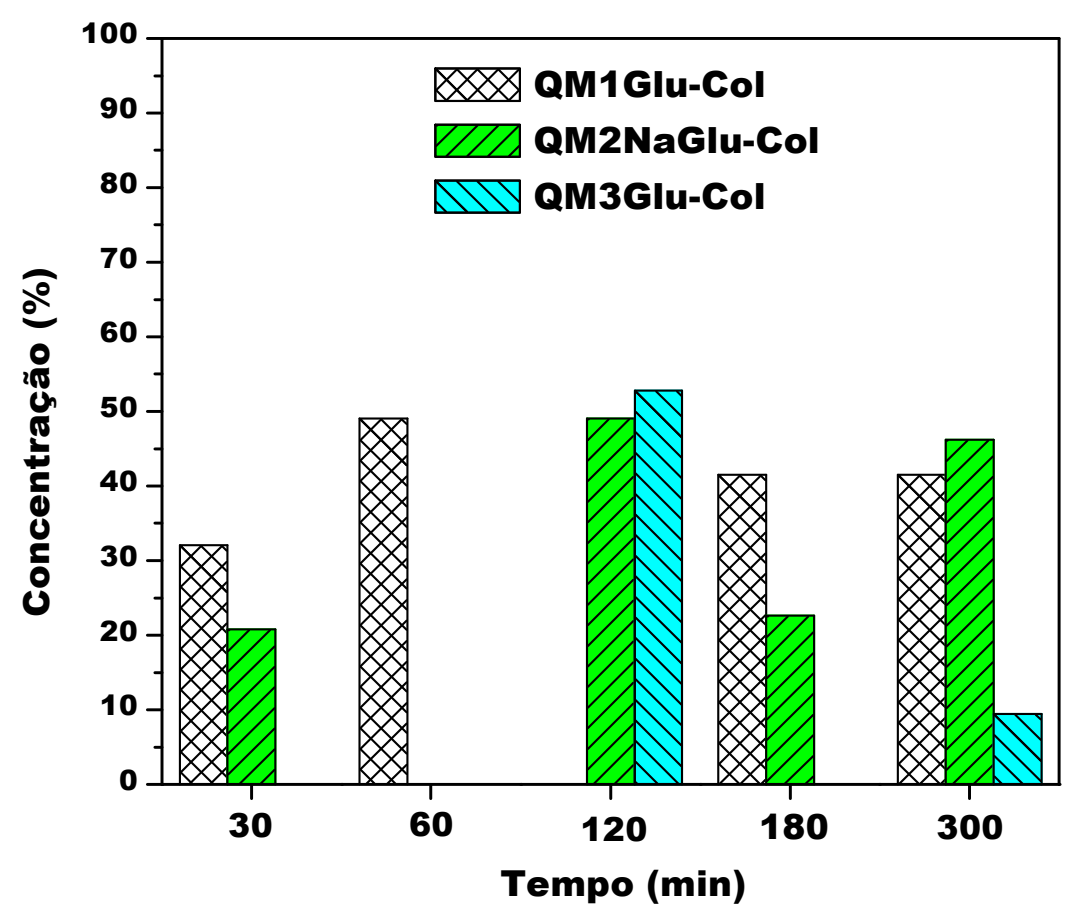

FIGURA 35 - Imobilização do colágeno nas partículas de quitosana magnéticas.

\section{V.7.1.3. Tripsina}

Os ensaios com a enzima tripsina foram realizados verificando-se, também, a eficácia de imobilização em partículas magnéticas sem o tratamento com o glutaraldeído.

Assim como observado para BSA, em 30 min ocorreu a imobilização da tripsina nas QM funcionalizadas com o glutaraldeído, sendo entretanto, encontrado valores de porcentual maiores. Em 30 min, a imobilização da tripsina variou de $43 \%$ a $62 \%$, como pode ser verificado na FIG. 36 e TAB. 15. A mesma figura mostra também que as QM1 e QM2Na, sem glutaraldeído, apresentaram resultados similares, ou seja, imobilizaram um porcentual de $50 \%$ de tripsina em 60 min de incubação. Por outro lado, a QM3, sem glutaraldeído, apresentou o melhor resultado com $88 \%$ de tripsina imobilizada. Este fato leva a supor que o grupo amino da quitosana apresenta maior afinidade pela tripsina do que o grupo carbonila do glutaraldeído. Com relação às QM1 e QM2Na, sem glutaraldeído, as quais foram submetidas às etapas de secagem e precipitação, respectivamente, 
apresentaram uma eficácia menor do que a QM3 possivelmente porque apresentavam um menor número de grupos amino disponível. Devido ao alto rendimento de imobilização da tripsina na QM3, estudou-se a sua atividade enzimática com BapNa.

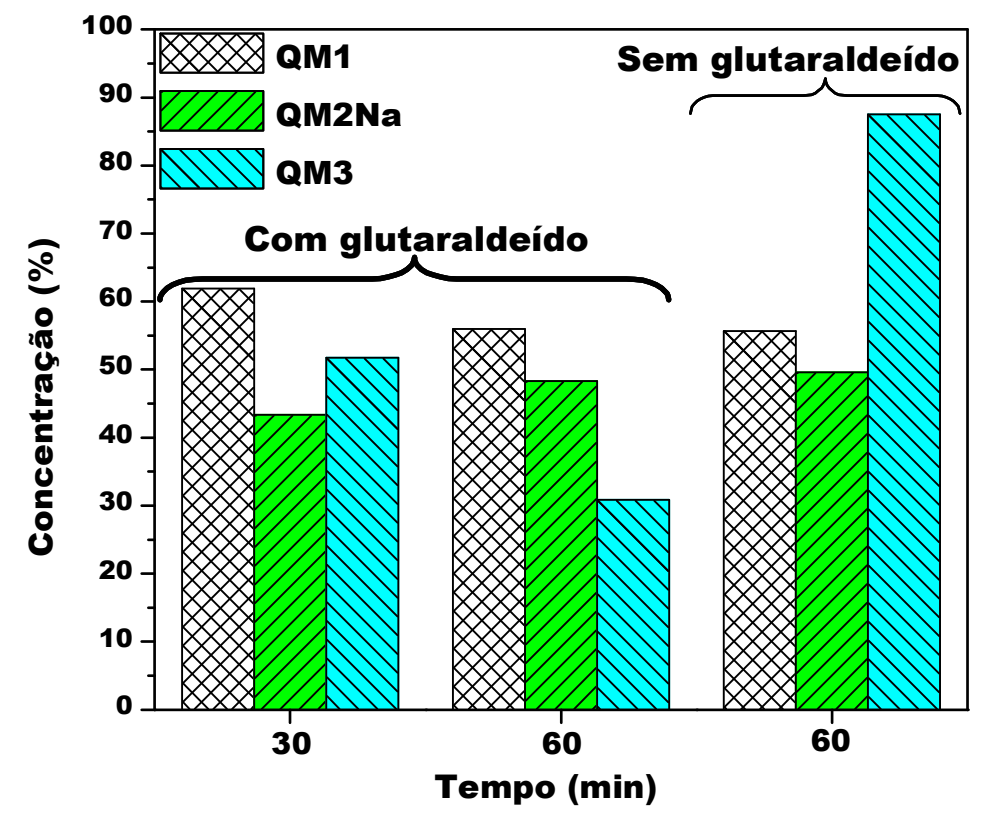

FIGURA 36 - Imobilização da tripsina nas partículas de quitosana magnéticas em diferentes tempos de incubação. $[$ Trip $]=2 \mathrm{mg} \cdot \mathrm{mL}^{-1}$

TABELA 15 - Percentual imobilizado com variação de tempo de incubação da tripsina nas partículas de quitosana magnéticas.

\begin{tabular}{cccc}
\hline Tempo $(\boldsymbol{m i n})$ & QM1 & QM2Na & QM3 \\
\hline 30 & 61,9 & 43,3 & 51,7 \\
60 & 55,9 & 48,3 & 30,8 \\
${ }^{* *} 60$ & 55,6 & 49,5 & 87,5 \\
\hline${ }^{* \star}$ Sem glutaraldeído & &
\end{tabular}




\section{V.7.1.4. Atividade enzimática}

A atividade enzimática da tripsina imobilizada foi verificada adicionando-se BApNa às QM3-Trip e QM3Glu-Trip na proporção 950/50 $\mu \mathrm{L}$. Para retirar o excesso de enzima que supostamente estivesse apenas em contato superficial e pudesse vir a alterar os resultados, as partículas magnéticas foram submetidas à lavagens com $\mathrm{HCl} 0,001 \mathrm{M}$. A atividade enzimática da tripsina foi avaliada após 5 dias e 30 dias imobilizada nas partículas de quitosana magnéticas, e o resultado está apresentado na FIG. 37.

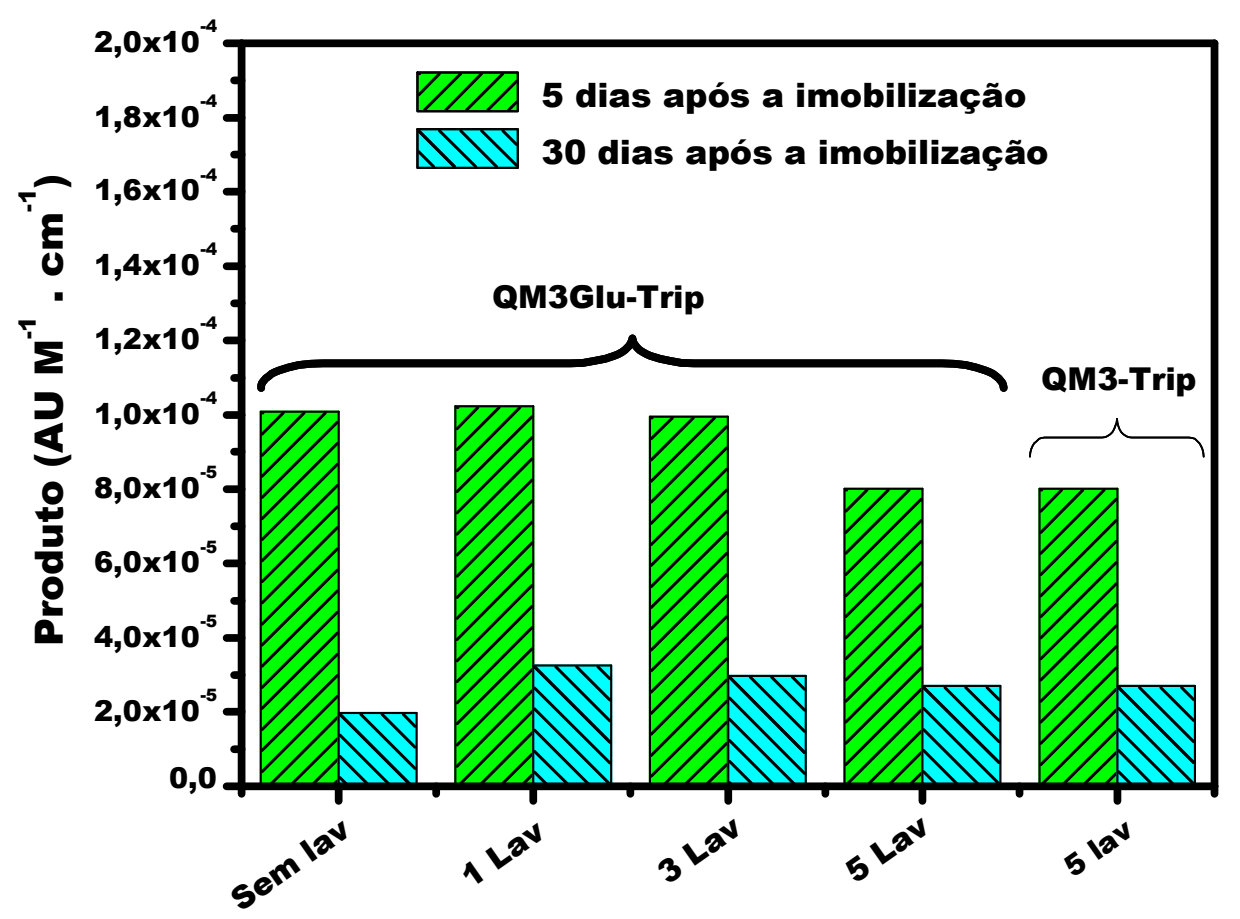

FIGURA 37 - Atividade enzimática da tripsina nas partículas de QM3-Trip e

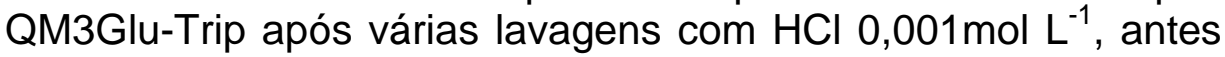
dos ensaios.

[Trip-carga] $=0,1 \mathrm{mg} \cdot \mathrm{mL}^{-1}$.

A atividade medida manteve-se constante, tanto nos compósitos lavados, quanto nos não lavados, confirmando que não havia enzima dispersa no meio, e que ela realmente estava imobilizada no material ensaiado. A partir da $5^{a}$. lavagem a atividade começou a diminuir tanto da QM3-Trip quanto da QM3Glu-Trip, 
indicando a remoção da enzima imobilizada na superfície das partículas magnéticas.

Os ensaios mostraram que nas duas QM3, funcionalizada e não funcionalizada, mesmo 30 dias após a incubação, a tripsina ainda estava imobilizada e ativa. Porém a atividade tinha diminuído para $30 \%$ daquela observada com 5 dias de incubação.

Como a QM3-trip e QM3Glu-trip apresentaram o mesmo comportamento quanto à atividade enzimática, estudou-se a cinética para definir o carreador de tripsina mais adequado.

\section{V.7.1.5. Cinética enzimática}

\section{V.7.1.5.1. Tripsina carga}

A FIG. 38 ilustra a formação do produto $(P)$ e as velocidades das reações catalisada pela tripsina (Trip-carga), cuja concentração foi mantida constante, variando-se a concentração do substrato (BApNA).

Conforme previsto pelo modelo cinético de Michaelis-Menten para reações de monossubstrato, em baixa concentração [S1] a enzima permanece em equilíbrio entre a forma livre $[E]$ e o complexo enzima-substrato [ES]. Observa-se que em S5, concentração maior, a velocidade da reação é maior quando comparada a $S 4$, e assim sucessivamente, indicando que a concentração do substrato tem influência direta na velocidade de formação do produto. 


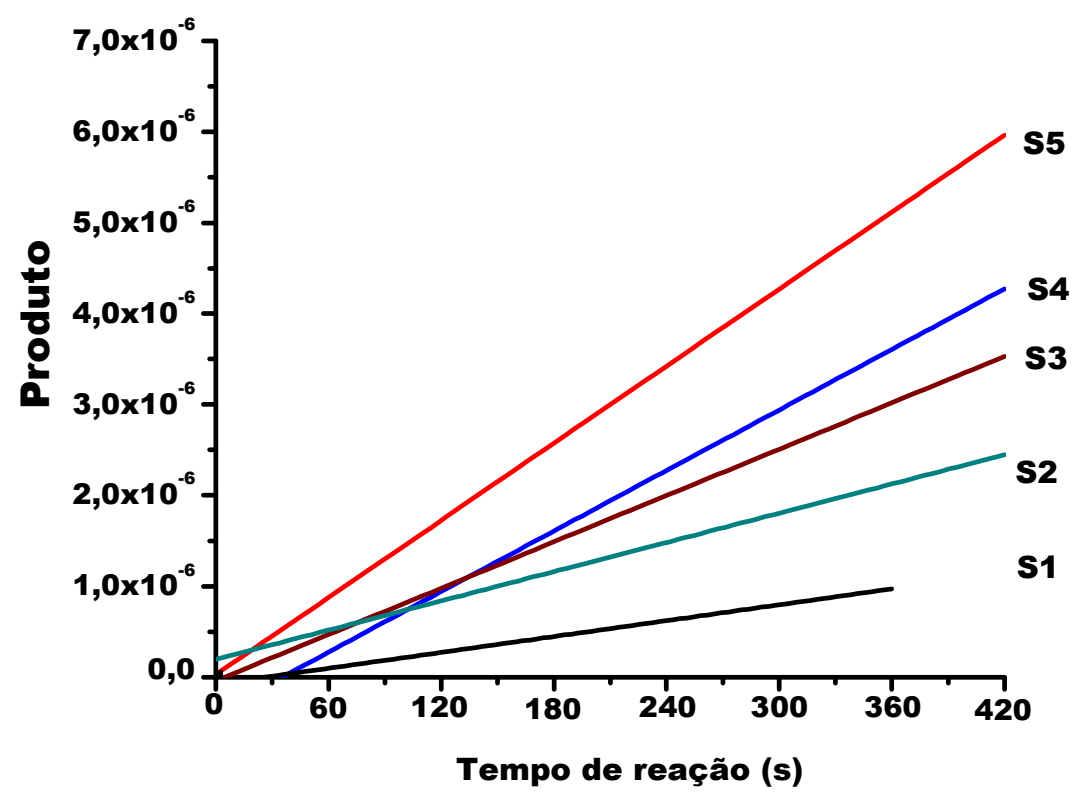

FIGURA 38 - Efeito da concentração do substrato BApNA na velocidade da reação catalisada pela tripsina (Trip-carga).

As velocidades de reação para as diferentes concentrações de substratos foram relacionadas no gráfico dos recíprocos de Lineweaver-Burk (1/v x 1/[S]), que se baseia no rearranjo linear da equação de Michaelis-Menten (FIG. 39).

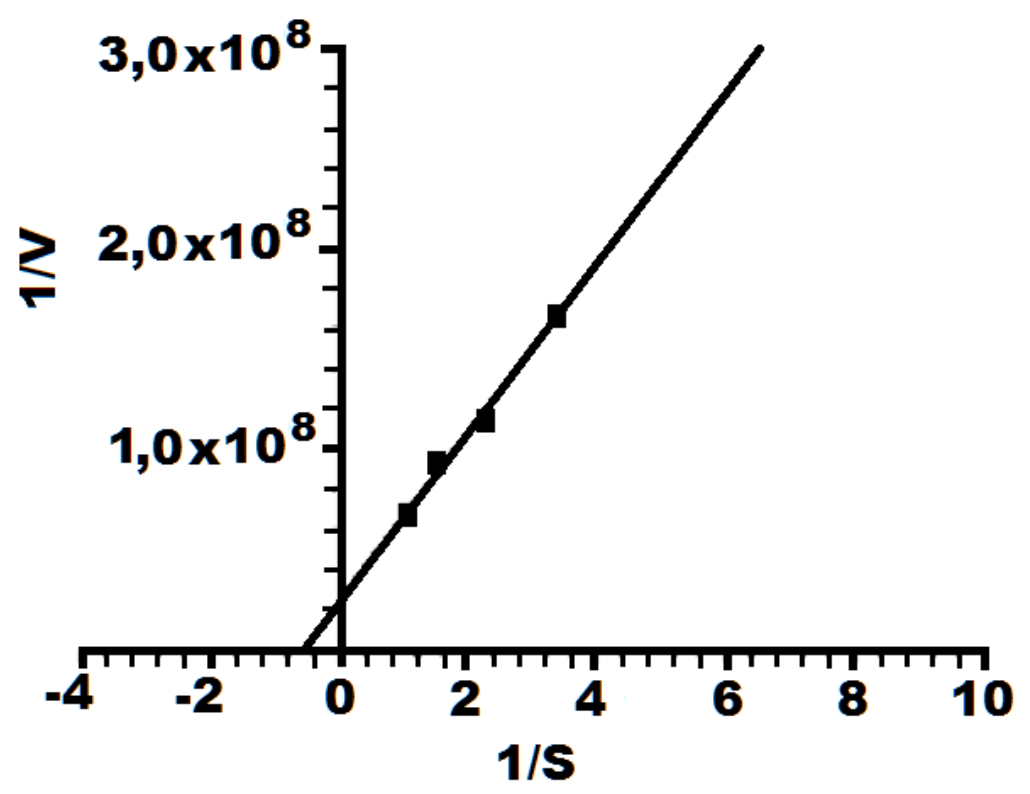

FIGURA 39 - Gráfico duplo-recíproco ou de Lineweaver-Burk baseado nos resultados obtidos nos ensaios com a Trip-carga 
No ajuste dos dados da Trip-carga pelo modelo de regressão linear, obteve-se $R^{2}=0,9931$ de coeficiente de correlação linear. $O$ valor de $K_{m}$ foi 1,60 $\mathrm{mM}$ e a $V_{\max }$ foi $3,8 \times 10^{-8} \mu \mathrm{M} \cdot \mathrm{min}^{-1}$.

A relação $V_{\max } / K_{m}$ indica a afinidade da enzima pelo substrato. Foi obtido o valor de $2,40 \times 10^{-8}$ para a tripsina carga.

\section{V.7.1.5.2. Partículas magnéticas (QM3-Trip)}

As partículas magnéticas não tratadas com glutaraldeído (QM3-Trip) apresentaram atividade ao serem colocadas em contato com o substrato. No entanto, a sua separação magnética do meio reacional foi muito lenta e incompleta, deixando muitas partículas magnéticas dispersas no meio. Esse evento dificultou a realização das leituras no espectrofotômetro, causando interferências nas medidas da absorbância, e aumentando o tempo de intervalo das leituras, uma vez que havia a necessidade de se manter o material sob a ação do campo magnético por um tempo maior, além do intervalo de 1 min, para o aprisionamento das partículas à parede do microtubo e posterior retirada da parte líquida. Após algumas tentativas de acelerar esse processo, percebeu-se que esse material não era adequado para os ensaios de cinética enzimática, não fornecendo dados confiáveis. Frente a esta dificuldade experimental esses resultados foram desprezados.

\section{V.7.1.5.3. Partículas magnéticas (QM3Glu-Trip)}

Para a enzima imobilizada com glutaraldeído (QM3Glu-Trip) (FIG. 40) obteve-se um $K_{m}$ de $1,08 \mathrm{mmol} \mathrm{L}^{-1}$ e $V_{\max } 3,00 \times 10^{-7} \mu \mathrm{M} \mathrm{min}^{-1}$. A relação $V_{\max } / K_{m}$ foi $2,77 \times 10^{-7}$, caracterizando que a enzima imobilizada com glutaraldeído tem uma afinidade pelo substrato 11 vezes maior que a enzima livre. Este resultado indica que a imobilização facilitou a formação do complexo [ES]. 


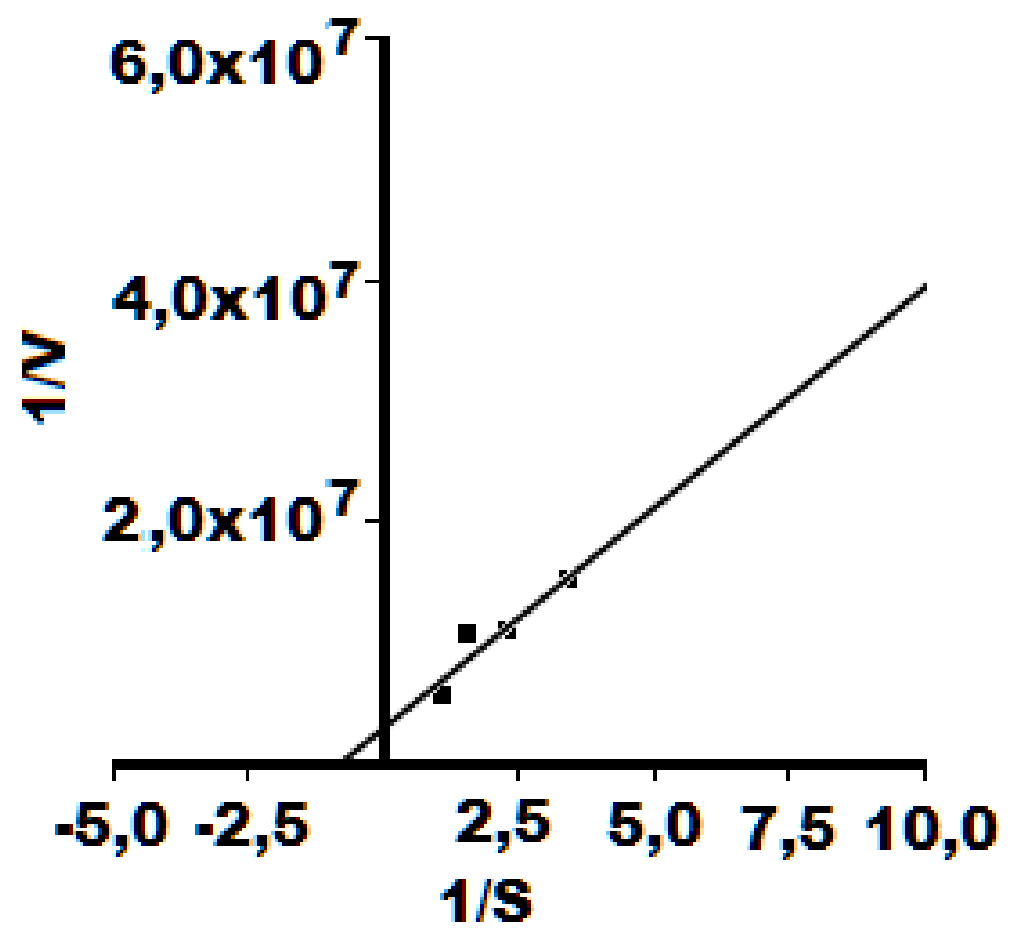

FIGURA 40 - Gráfico duplo-recíproco ou de Lineweaver-Burk da tripsina na QM3Glu-Trip 


\section{CONCLUSÕES}

A obtenção dos compósitos, partículas de magnetita-quitosana, foi realizada com sucesso, empregando-se uma metodologia relativamente simples, na qual as partículas magnéticas, produzidas por meio da precipitação simultânea dos íons $\mathrm{Fe}^{2+}$ e $\mathrm{Fe}^{3+}$ em solução de $\mathrm{NaOH}$, foram vertidas sobre um solução de quitosana, obtendo-se dois tipos de compósitos, sendo um por secagem direta e outro por meio de uma etapa adicional de reprecipitação da quitosana seguida de secagem.

Os compósitos apresentaram características de materiais com propriedades superparamagnéticas e, portanto, eficientes na aplicação da técnica de separação magnética sólido-líquido.

A caracterização comprovou a formação de nanopartículas superparamagnéticas combinadas com quitosana, sem contudo apresentar diferenças significativas entre os compósitos. Segundo os resultados de DSC, o compósito submetido à precipitação com $\mathrm{NaOH}$ apresentou um pequeno aumento na estabilidade térmica, em comparação com o que não sofreu a reprecipitação da quitosana.

Por meio desses estudos é possível afirmar que houve a imobilização das proteínas BSA, colágeno e tripsina na superfície das partículas QM1Glu, QM2NaGlu, QM3Glu em 30 min de incubação. A tripsina apresentou maior afinidade pelas partículas magnéticas (QM), seguida pela proteína albumina. Houve problemas para a dissolução do colágeno em meio aquoso, mesmo com o aquecimento da água de dissolução; esse fato dificultou a imobilização dessa proteína nas QM. Para a tripsina, verificou-se que as partículas de QM3 não funcionalizadas apresentaram maior potencial de imobilização do que QM3Glu.

Por meio dos ensaios de atividade enzimática da tripsina, verificou-se que, 30 dias após a incubação, a tripsina ainda estava imobilizada e ativa nas 
partículas QM3-trip e QM3Glu-trip, confirmando a possibilidade de sua reutilização por um bom período de tempo.

No estudo cinético, as partículas sem o tratamento com o glutaraldeído (QM3-Trip) ficaram muito dispersas, criando dificuldade para a sua remoção do meio reacional com o campo magnético, em intervalos de tempo regulares, gerando dados inconsistentes no momento do ensaio espectrofotométrico, mostrando-se inviáveis para esse tipo de ensaio

Por outro lado, as partículas funcionalizadas com o glutaraldeído (QM3Glu-Trip), além de se magnetizarem com facilidade quando expostas a um campo magnético, apresentaram afinidade pelo substrato, reagindo no tempo preestabelecido para a sua clivagem, fornecendo resultados coerentes no ensaio de cinética enzimática.

As QM sintetizadas e funcionalizadas apresentaram boas perspectivas de aplicação como carreadoras de BSA, colágeno e tripsina em ensaios biológicos, cuja a separação sólido-líquido poderá ser realizada por técnica de separação magnética. 


\section{REFERÊNCIAS BIBLIOGRÁFICAS}

ABARRA, E.N.; ACHARYA, B.R.; INOMATA, A.; AJAN, A.; OKAMOTO, I. Synthetic ferrimagnetic media. Sci. Tech., v. 37, p. 145-154, 2001.

ALBERTS, B.; BRAY, D.; JOHNSON, A.; LEWIS, J.; RAFF, M.; ROBERTS, K.; WALTER, P. Fundamentos da biologia celular. Porto Alegre: Artmed, 1999a, cap. 5, Estrutura e função das proteínas. p. 135-184.

ALBERTS, B.; BRAY, D.; JOHNSON, A.; LEWIS, J.; RAFF, M.; ROBERTS, K.; WALTER, P. Fundamentos da biologia celular. Porto Alegre: Artmed, 1999b, cap. 3, Energia, catálise e biosíntese. p. 135-184.

ALBERTS, B.; JOHNSON, A.; LEWIS, J.; RAFF, M.; ROBERTS, K.; WALTER, P.; BRAY, D.; WATSON, J.D. Molecular biology of the cell, 4th edition, New York: Garland Science, 2002. Disponível em: <http://www.ncbi.nlm.nih.gov/books/NBK26830/>Acesso em:01 jan. 2010.

ANTONINO, N.A. Otimização do processo de obtenção de quitina e quitosana de exoesqueletos de camarões oriundos da indústria pesqueira paraibana, 2007, Mestrado (Dissertação), Universidade Federal da Paraíba, João Pessoa - PB.

ARANAZ, I.; MENGÍBAR, M.; HARRIS, R.; PAÑOS, I.; MIRALLES, B.; ACOSTA, N.; GALED, G.; HERAS, A. Functional characterization of chitin and chitosan. Curr. Chem. Biol., v. 3, p. 203-230, 2009.

AZEVEDO, V.V.C.; CHAVES, S.A.; BEZERRA, D.C.; LIA FOOK, M.V.; COSTA, A.C.F. M. Quitina e quitosana: aplicações como biomateriais. Rev. Eletr. Mat. Proc., v. 2.3, p. 27-34, 2007.

BADAWY, M.E.I.; RABEA, E.I. A biopolymer chitosan and its derivatives as promising antimicrobial agents against plant pathogens and their applications in crop protection. Int. J. Carb. Chem., v. 2011, p. 29, 2011.

BARRON, A.R. The Early History of Nanotechnology. Disponível em: <http://cnx.org/content/m14504/1.1/>. Acesso em: 01 jul. 2010.

BATTISTI, M.V.; CAMPANA-FILHO, S.P. Obtenção e caracterização de $\alpha-$ quitina e quitosanas de cascas de Macrobrachium rosembergii. Quim. Nova, v. 31, n. 8, p. 2014-2019, 2008.

BENICEWICZ, B.C.; HOPPER, P.K. Review : Polymers for absorbable surgical sutures - part II. v. 6, p. 64-94, J Bioact. Comp. Pol., 1991.

BERGER, P.; ADELMAN, N.B.; BECKMAN, K.J.; CAMPBELL, D.J.; ELLIS, A.B.; LISENSKY, G.C. Preparation and properties of an aqueous ferrofluid. J. Chem. Educ., v.76, n. 7, p. 943-948, 1999. 
BERRY, C.C.; CURTIS, A.S.G. Functionalisation of magnetic nanoparticles for applications in biomedicine. J. Phys. D: Appl. Phys. v. 36, p. 198-206, 2003.

BHATIA, S.C.; RAVI, N. A Magnetic Study of an Fe-chitosan complex and Its relevance to other biomolecules. Biomacromolecules, v. 1, p. 413-417, 2000.

BHATTARAI, S.R.; KC, R.B.; KIM, S.Y.; SHARMA, M.; KHIL, M.S.; HWANG, P.H.; CHUNG, G.H.; KIM, H.Y. N-hexanoyl chitosan stabilized magnetic nanoparticles: Implication for cellular labeling and magnetic resonance imaging. J. Nanobiotechnology, v. 6, n. 1, p. 1-9, 2008.

BRADFORD, M. a rapid and sensitive method for the quantitation of microgram quantities of protein utilizing the principle of protein-dye binding. Anal. Biochem., v. 72, p. 248-254, 1976.

BRENA, B.M.; BATISTA-VIERA, F. Methods in Biotechnology: Immobilization of Enzymes and Cells, 4th edition, Totowa, NJ, J. M. Guisan (C) Humana Press Inc., 2006 Disponível em: $<$ http://www.springer.com/978-1-58829-290-2> Acesso em:27 mar. 2010, p. 15-30.

CAMARGO, P.H.C.; SATYANARAYANA, K.G.; WYPYCH, F. Nanocomposites: synthesis, structure, properties and new application opportunities. Mater. Res., v. 12, n. 1, p. 1-39, 2009.

CAMPANA FILHO, S.P.; SIGNINI, R. Efeito de aditivos na desacetilação de quitina. Polímeros, v. 11, n. 4, p. 169-173, 2001.

CAMPANA-FILHO, S.P.; BRITTO, D.; CURTI, E.; ABREU, F.R.; CARDOSO, M.B.; BATTISTI, M.V.; SIM, P.C.; GOY, R.C.; SIGNINI, R.; LAVALL, R.L. Extração, estruturas e propriedades de $\alpha$ - e $\beta$-quitina. Quim. Nova, v. 30, n. 3, p. 644-650, 2007.

CAMPBELL, F.C. Introduction to composite materials. Disponível em: $<$ www.asminternational.org $>$. Acesso em: 17 set. 2010.

CASTRO, V.F.; CELESTINO, J.; QUEIROZ, A.A.A.; GARCIA, F.G. Propriedades magnéticas e biocompatíveis de nanocompósitos para utilização em magneto-hipertermia. Rev. Bras. Fís. Med. v. 4, n. 1, p.7982, 2010.

CULLITY, B.D. Introduction to magnetic materials. Addison Wesley Publishing Company, 1972

CULLITY, B.D.; GRAHAM, C.D. Introduction to Magnetic Materials, 2th ed., Wiley-IEEE Computer Society Press, New Jersey, USA, 2009.

D’AYALA, G.G.; MALINCONICO, M.; LAURIENZO, P. Review: Marine derived polysaccharides for biomedical applications: chemical modification approaches. Molecules, v. 13, p. 2069-2106; 2008.

DABDOUB, M.J.; BRONZEL,J.L. Biodiesel: visão crítica do status atual e perspectivas na academia e na indústria. Quim. Nova, v. XY, n. 00, p 1-17, 200_] 
DHANIKULA, A.B.; PANCHAGNULA, R. Chitosan films for local delivery of paclitaxel. AAPS. J., v. 6, n. 3, 2004.

DIAS, A.M.G.C.; HUSSAIN, A., MARCOS, A.S.; ROQUE, A.C.A. A biotechnological perspective on the application of iron oxide magnetic colloids modified with polysaccharides. Biotechnol. Adv., v. 29, p. 142155, 2011.

DREXLER, E. Engines of Creation. The Coming Era of Nanotechnology. 1986. Disponível em : < http://xaonon.dyndns.org/misc/engines of creation.pdf $>$. Acesso em: 27 maio 2010.

DREXLER, K.E. Molecular engineering: An approach to the development of general capabilities for molecular. Proc. NatI. Acad. Sci. U.S.A., v. 78, n. 9, p. 5275-5278, 1981.

DUTTA, P.K.; DUTTA, J.; TRIPATHI, V.S. Chitin and chitosan: chemistry, properties and applications. J. Sci. Ind. Res., v. 63, p. 20-31, 2004.

ERLANGER, B .F.; KOKOWSKY, N.; COHEN, W. The preparation and properties of two new chromogenic substrates of trypsin. Arch. Biochem. Biophys., n. 95, v.2, p. 271-278, 1961.

Expasy proteomics server. Disponível em: <http://www.expasy.org/cgibin/protparam1?P00761@9-231@>. Acesso em: 09 set. 2010.

FAN, M.; HU, Q.; SHEN, K. Preparation and structure of chitosan soluble in wide pH range. Carbohydr. Polym., n. 78, p. 66-71, 2009.

FANFAIR, D., DESAI, S., KELTY, C. The Early History of Nanotechnology. 2005. Disponível em: <http://cnx.org/content/m14504/1.1/>. Acesso em: 01 jul. 2010.

FÁVERE, V.T.; RIELLA, H.G.; ROSA ,S. Cloreto de n-(2-hidroxil) propil-3trimetil amônio quitosana como adsorvente de corantes reativos em solução aquosa. Quim. Nova, v. 33, n. 7, p. 1476-1481, 2010.

FERGUSON, R.M.; MINARD, K.M.; KRISHNAN, K.M. Optimization of nanoparticle core size for magnetic particle imaging. J. Magn. Magn. Mater., v. 321, n. 10, p. 1548-1551, 2009.

FEYNMAN, R.P. There's Plenty of Room at the Bottom, 1959. Disponível em: <http://www.zyvex.com/nanotech/feynman.html> Acesso em 23 fev. 2011.

FORTINA, P.; KRICKA, L.J.; SURREY, S.; GRODZINSKI, P. Nanobiotechnology: the promise and reality of new approaches to molecular recognition. Trends Biotechnol., v. 23, n. 4, p. 168-173, 2005.

FOWLER, P.A.; HUGHES, J.M.; ELIAS, L.M. Biocomposites: technology, environmental credentials and market forces. J. Sci. Food. Agric., v. 86, p. 1781-1789, 2006.

GAO, Q.; CHEN, F.; ZHANG, J.; HONG, G.; NI, J.; WEI, X.; WANG, D. The study of novel $\mathrm{Fe}_{3} \mathrm{O}_{4} @ \mathrm{~g}-\mathrm{Fe}_{2} \mathrm{O}_{3}$ core/shell nanomaterials with improved properties. J. Magn. Magn. Mater., v. 321 , p. 1052-1057, 2009.

GATTESCHI, D.; SESSOLI, R.; CORNIA, A. Magnetism: general introduction. J. Magn. Magn. Mater., v. 2, p. 393-419, 2004. 
GOY, R.C.; BRITTO, D.; ASSIS, O.B.G. A review of the antimicrobial activity of chitosan. Polímeros, v. 19, n. 3, p. 241-247, 2009.

GUBIN, S.P.; KOKSHAROV, Y.A.; KHOMUTOV, G.B.; YURKOV, G.Y. Magnetic nanoparticles: preparation, structure and properties. Russ. Chem. Rev. v. 74, n. 6, p. 489-520, 2005.

GUO, L.; LIU,G.; HONG,R-Y; LI, H-Z. Preparation and characterization of chitosan poly(acrylic acid) magnetic microspheres. Mar. Drug., v. 8, p. 2212-2222, 2010.

HERNÁNDEZ, R.; ZAMORA-MORA, V.; SIBAJA-BALLESTERO, M.; VEGABAUDRIT, J.; LÓPEZ, D.; MIJANGOS, C. Influence of iron oxide nanoparticles on the rheological properties of hybrid chitosan ferrogels. $\boldsymbol{J}$. Colloid Interface Sci., v. 339, p. 53-59, 2009.

HOFMANN-AMTENBRINK, M.; VON RECHENBERG, B.; HOFMANN, H. Superparamagnetic nanoparticles for biomedical applications.

Nanostructured Materials for Biomedical Applications, 2009

HONG, R.Y.; LI, J.H.; QU, J.M.; CHEN, L.L.; LI, H.Z. Preparation and characterization of magnetite/dextran nanocomposite used as a precursor of magnetic fluid. Chem. Eng. J., v. 150, p. 572-580, 2009.

HONG, R.Y.; PAN, T.T.; HAN, Y.P.; LI, H.Z.; DING, J.; HAN, S. Magnetic field synthesis of $\mathrm{Fe}_{3} \mathrm{O}_{4}$ nanoparticles used as a precursor of ferrofluids. $\boldsymbol{J}$. Magn. Magn. Mater., v. 310, p. 37-47, 2007.

HOSSEININAVEH, V.; BANDANI, A.; HOSSEININAVEH, F. Digestive proteolytic activity in the sunn pest, Eurygaster integriceps. J. Insect Sci., v. 9, n. 70, p.1-11, 2009.

HUBER, D.L. Synthesis, Properties, and Applications of Iron Nanoparticles, Small, v. 1, p. 482-501, 2005. Disponível em: <http://onlinelibrary.wiley.com/doi/10.1002/chin.200547224/pdf>. Acesso em: 15 fev 2011.

HUGHES, G.A. Nanostructure-mediated drug delivery. Nanomed. Nanotechnol. Biol. Med., v. 1, p. 22-30, 2005.

JANEGITZ, B.C.; LOURENÇÃO, B.C.; LUPETTI, K.O.; FATIBELLO-FILHO, O. Desenvolvimento de um método empregando quitosana para remoção de íons metálicos de águas residuárias, Quim. Nova, v. 30, n. 4, p. 879-884, 2007.

JOSÉ, N. M.; PRADO. L.A.S.A. Materiais híbridos orgânico-inorgânicos: preparação e algumas aplicações. Quim. Nova, v. 28, n. 2, p. 281-288, 2005.

JUDY, J.W. Batch-fabricated ferromagnetic microactuators with silicon flexures, 1996, PhD (Thesis), University of California, Berkeley.

JUNG, H.I.; HUH, S.H.; OH, S.J.; KIM, Y.N.; KIM, H.K.; PARK, J.W.; CHUNG, J.J.; LEE, G.H. Oxidation enthalpy of $6 \mathrm{~nm}$ Fe clusters. J. Korean Phys. Soc., v. 35, n. 3, pp. 265-267, 1999. 
KAWACHI, E. Y.; BERTRAN, C. A.; REIS, R. R.; ALVES, O. L. Biocerâmicas: Tendências perspectives de uma área interdisciplinar. Quim. Nova, v. 23, n. 4, p. 518-522, 2000.

KHOUSHAB, F.; YAMABHAI, M. Chitin research revisited. Mar. Drugs., v. 8, p. 1988-2012; 2010.

LANGLAIS, B.; LESUR, V.; PURUCKER, M.E.; CONNERNEY, J.E.P.; MANDEA, M. Crustal magnetic fields of terrestrial planets. Space Sci. Ver., DOI 10.1007/s11214-009-9557-y, 2009.

LATHAM, A. H.; WILLIAMS, M. E. controlling transport and chemical functionality of magnetic nanoparticles. Acc. Chem. Res., v. 41, p. 411420, 2008.

LEE, L.J.; ZENG, C.; CAO, X.; HAN, X.; SHEN, J.; XU, G. Polymer nanocomposite foams. Compos. Sci. Technol., v. 65, p. 2344-2363, 2005.

LEE, W.F.; HUANG, X.T. Immobilization of trypsin by thermo-responsive hidrogel for the affinity separation of trypsin inhibitor, Desalination, v. 234, p. 195-203, 2008.

LEHNINGER, D.L.; NELSON, D.A.; COX, M.M. Princípios da bioquímica. 4a․ Edição, Ed. Sarvier (Almed), 2000, cap. 8, enzimas, p. 147-176.

LEHNINGER, D.L.; NELSON, D.A.; COX, M.M. Principles of biochemistry. 4ed. Nova lorque: W. H. Freeman, 2004, cap. 6, enzymes, p. 190-237.

LI, G.Y.; JIANG, Y.R.; HUANG, K.L.; DING, P.; CHEN, J. Preparation and properties of magnetic $\mathrm{Fe}_{3} \mathrm{O}_{4}$-chitosan nanoparticles. J. Alloys Compd. v. 466, p. 451-456, 2008.

LI, L.; JIANG, J.; XU, F. Synthesis and ferrimagnetic properties of novel Smsubstituted LiNi ferrite-polyaniline nanocomposite. Mater. Lett., v. 61, p. 1091-1096, 2007.

LIU, T-Y.; HU, S-H.; HU, S-H.; TSAI, S-P.; CHEN, S-Y. Preparation and characterization of thermal-sensitive ferrofluids for drug delivery application. J. Magn. Magn. Mater., v. 310, p. 2850-2852, 2007.

MAGALHAES, A.; DA FONSECA, B.C.; DINIZ, C.R.; GILROY, J.; RICHARDSON, M. The complete amino acid sequence of a thrombin-like enzyme/gyroxin analogue from venom of the bushmaster snake (Lachesis muta muta). FEBS Lett., v. 329, p.116-120, 1993.

MAHMOUDI, M.; SIMCHI, A.; IMANI, HÄFELI, U.O. Superparamagnetic iron oxide nanoparticles with rigid cross-linked polyethylene glycol fumarate coating for application in imaging and drug delivery. J. Phys. Chem. C., v. 113, p. 8124-8131, 2009.

MARTEN, G.U.; GELBRICH,T.; SCHMIDT, A.M. Hybrid biofunctional nanostructures as stimuli-responsive catalytic systems. Beilstein J. Org. Chem., v. 6, p. 922-931, 2010.

MEYER, W.L.; LIU, Y.; SHI, X-W.; YANG, X.; BENTLEY, W.E.; PAYNE, G.F. Chitosan-coated wires: conferring electrical properties to chitosan fibers.

Biomacromolecules, v. 10, p. 858-864, 2009. 
MONTEIRO JR., O.A.C.; AIROLDI, C. Some studies of crosslinking chitosanglutaraldehyde interaction in a homogeneous system. Int. J. Biol. Macromol., v. 26, p. 119-128, 1999.

NAIR, L.S.; LAURENCIN, C.T. Biodegradable polymers as biomaterials. Prog. Polym. Sci., v. 32, p. 762-798, 2007.

NAKAJIMA, M.; ATSUMI, K.; KIFUNE, K.; MIURA, K.; KANAMARU, H. Chitin is an effective material for sutures. Jpn. J. Surg., v. 16, n. 6, p. 418-424, 1986.

NAYAK, U.Y.; GOPAL, S.; MUTALIK, S.; RANJITH, A.K.; SREENIVASA, M.; GUPTA, P.; UDUP, N. Glutaraldehyde cross-linked chitosan microspheres for controlled delivery of Zidovudine. J. Microencapsulation, v. 26, n. 3, p. 214-222, 2009.

NEDKOV, I.; SLAVOV, L.; MERODIISKA, T.; LUKANOV, P.; TAILHADES, PH.; GOUGEON, M.; VANDENBERGHE, R.E. Size effects in monodomain magnetite based ferrofluids. J. Nanopart. Res., v. 10, p. 877-880, 2008.

NETO, C.G.T.; GIACOMETTI, J.A.; JOBB, A.E.; FERREIRA, F.C.; FONSECA, J.L.C.; PEREIRA, M.R. Thermal analysis of chitosan based networks. Carbohyd. Polym., v. 62, p. 97-103, 2005.

OGAWA, K. effect of heating an aqueous suspension of chitosan on the crystallinity and polymorphs. Agric. Biol. Chem., v. 55, n. 9, p. 2375-2379, 1991.

OGAWA, K.; YUI, T.; MIYA, M. Dependence on the preparation procedure of the polymorphism and crystallinity of chitosan membranes. Biosci.

Biotech. Biochem., v. 56, n. 6, p. 858-862, 1992.

ORTEGA, D.; VÉLEZ-FORT, E.; GARCÍA, D. A.; GARCÍA, R.; LITRÁN, R.; BARRERA-SOLANO, C.; RAMIIREZ-DEL-SOLAR, M.; DOMÍNGUEZ, M. Size and surface effects in the magnetic properties of maghemite and magnetite coated nanoparticles. Phil. Trans. R. Soc. A., v. 368, p. 44074418, 2010.

PANESAR, P.S.; KUMARI, S.; PANESAR,R. Review article: Potential applications of immobilized $\beta$-galactosidase in food processing industries. Enzyme Res., v. 2010, p. 1-16, 2010.

PANKHURST, Q. A.; CONNOLLY, J.; JONES, S .K.; DOBSON, J. Applications of magnetic nanoparticles in biomedicine. J. Phys. D: Appl., Phys., v. 36, p 167-181, 2003.

PAVON, L.F.; OKAMOTO, O.K. Aplicações de recursos nanobiotecnológicos em câncer. einstein; v. 5, n. 1, p. 74-77, 2007.

PENICHE-COVAS, C.; ARGÜELLES-MONAL, W.; SAN ROMÁN, J. A. kinetic study of the thermal degradation of chitosan and a mercaptan derivative of chitosan. Polym. Degrad. Stab., v. 39, p. 21-28, 1993.

PEREIRA, F.C.; BERGAMO, E.P.; ZANONI, M.V.B.; MORETTO, L.M.; UGO, $P$. Aplicações de nanoeletrodos como sensores na química analítica.

Quim. Nova, v. 29, n. 5, p. 1054-1060, 2006. 
PILLAI, C.K.S.; PAUL, W.; SHARMA, C.P. Chitin and chitosan polymers: chemistry, solubility and fiber formation. Prog. Polym. Sci., v. 34, p. 641678, 2009.

QUIMING, N.S.; VERGEL, R.B.; NICOLAS, M.G.; VILLANUEVA, J.A. Interaction of bovine serum albumin and metallothionein, J. Heath Sci., v. 51, n. 1, p. 8-15, 2005.

RICCA, E.; CUTTING, S.M. Emerging applications of bacterial spores in nanobiotechnology. J. Nanobiotechnol., v. 1, p. 1-10, 2003.

RINAUDO, M. Chitin and chitosan: Properties and applications. Prog. Polym. Sci., v. 31, p. 603-632, 2006.

SALATA, O.V. Applications of nanoparticles in biology and medicine. $\boldsymbol{J}$ Nanobiotechnol., v. 2, n. 3, 2004.

SANTANA, G.P.; RAMOS, A.M.; FABRIS, J.D. Uma estratégia adaptada para síntese de magnetita. Quim. Nova, v. 31, n. 2, p. 430-432, 2008.

SHAN, Z.; YANG, W.S.; ZHANG, X.; HUANGA Q.M.; YE, H. Preparation and characterization of carboxyl-group functionalized superparamagnetic nanoparticles and the potential for bio-applications. J. Braz. Chem. Soc., v. 18, n. 7, p. 1329-1335, 2007.

SHELDON, R.A. Enzyme immobilization: The quest for optimum performance. Adv. Synth. Catal., v. 349, p. 1289-1307, 2007.

SINNECKER, J.P. Materiais magnéticos doces e materiais e ferromagnéticos amorfos. Rev. Bras. Ens. Fis., v. 22, n. 3, p. 396-405, 2000.

SPAHN, C.; MINTEER, S.D. Enzyme immobilization in biotechnology. Recent Patents on Engineering, v. 2, p. 195-200, 2008.

SPIN-NETO, R.; PAVONE. C.; FREITAS, R.M.; MARCANTONIO, R.A.C.; MARCANTONIO-JÚNIOR, E. Biomateriais à base de quitosana com aplicação médica e odontológica: revisão de literatura. Revista de Odontologia da UNESP, v. 37, p. 155-161, 2008.

SUGIMOTO, M.; MORIMOTO, M.; SASHIWA, H.; SAIMOTO, H.; SHIGEMATA, Y. Preparation and characterization of water-soluble chitin and chitosan derivatives. Carbohydr. Polym., v. 36, p. 49-59, 1998.

SUNG, H.W.F.; RUDOWICZ, C. A closer look at the hysteresis loop for ferromagnets. Disponível em: <http://arxiv.org/ftp/condmat/papers/0210/0210657.pdf>. Acesso em: 2 set. 2010.

SZNAJD, J. Renormalization of ferrimagnetic alternating spin chains. J. Phys.: Condens. Matter., v. 18, n. 48 11047, 2006.

TARTAJ, P.; MORALES, M.P.; VEINTEMILLAS-VERDAGUER, S.; GONZÁLEZ-CARREÑO, T.; SERNA, C.J. The preparation of magnetic nanoparticles for applications in biomedicine. J. Phys. D: Appl. Phys., v. 36, p. r182-r197, 2003.

The Protein Model Portal. Disponível em: $<$ http://www.proteinmodelportal.org/?pid=modelDetail\&pmpuid=100000000 3609\&range from $=1 \&$ range to $=607 \& a c=P 02769 \& z i d=a s y n c>$. Acesso em: 09 set. 2010. 
THOREK, D.L.J.; CHEN, A.K.; CZUPRYNA, J.; TSOURKAS, A.

Superparamagnetic iron oxide nanoparticle probes for molecular imaging. Annals of Biomedical Engineering, DOI: 10.1007/s10439-005-9002-7, 2006.

TOMA, H.E. Interfaces e organização da pesquisa no Brasil: da química à nanotecnologia. Quím. Nova, v. 28, p. 48-51, 2005.

TONHI, E.; PLEPIS, A.M.G. Obtenção e caracterização de blendas colágenoquitosana. Quim. Nova. v. 25, n. 6, p. 943-948, 2002.

TURCU, R.; NAN, A.; CRACIUNESCU, I.; PANA, O.; LEOSTEAN, C.; MACAVEI, S. Smart composites based on magnetic nanoparticles and responsive polymers. J. Phys. Conf. Ser., v. 182, p. , 2009.

VO-DINH, T.; CULLUM, B.M.; STOKES, D. L. Nanosensors and biochips: frontiers in biomolecular diagnostics. Sens. Actuators, B., v. 74, n. 1-3, p. 2-11, 2001.

WANG, G.; HUANG, J.P. Nonlinear magnetic susceptibility of ferrofluids. Chem. Phys. Lett., v. 421, p. 544-548, 2006.

WANG, S-F.; TAN, Y-M. A novel amperometric immunosensor based on $\mathrm{Fe}_{3} \mathrm{O}_{4}$ magnetic nanoparticles/chitosan composite film for determination of ferritin. Anal. Bioanal. Chem., v. 387, p. 703-708, 2007.

WRIGHT, J. E. William Gilbert. Br. Med. J., v. 1, p. 83-85, 1975.

YOO, M.K.; KIM, I.Y.; KIM, E.M.; JEONG, W.J.; LEE, C.M.; JEONG, Y.Y.; AKAIKE,T.; CHO, C.S. Superparamagnetic iron oxide nanoparticles coated with galactose-carrying polymer for hepatocyte targeting. J. Biomed. Biotechnol., v. 2007, p. 2-9, 2007.

ZALICH, M.A. Physical properties of magnetic macromolecule-metal and macromolecule-metal oxide nanoparticle complexes, 2005, $\mathrm{PhD}$ (Thesis), Virginia Polytechnic Institute and State University, Blacksburg, Virginia.

ZHAO, D-L.; WANG, X-X.; ZENG, X-W.; XIA, Q-S.; TANG, J-T. Preparation and inductive heating property of Fe3O4-chitosan composite nanoparticles in an AC magnetic field for localized hyperthermia. J. Alloys Compd., v. 477, p. 739-743, 2009.

ZHAO, S.Y.; LEE, D.K.; KIM, C.W.; CHA, H.G.; KIM, Y.H.; KANG, Y.S. Synthesis of magnetic nanoparticles of fe3o4 and cofe2o4 and their surface modification by surfactant adsorption. Bull. Korean Chem. Soc., v. 27, n. 2, p. 237-242, 2006.

ZHAROV, V.P.; KIM, J-W.; CURIEL, D.T.; EVERTS, M. Self-assembling nanoclusters in living systems: application for integrated photothermal nanodiagnostics and nanotherapy. Nanomed. Nanotechnol. Biol. Med., v. 1, p. 326-345, 2005.

ZHOU, Y-M.; ZHANG, W-Q.; ZHONG, L-P.; WANG, D-S. Theoretical prediction of ferrimagnetism in face-centered cubic iron. J. Magn. Magn. Mater., v. 145, p. L273-L277, 1995. 
ZHU, A.; YUAN, L.; LIAO, T. Suspension of $\mathrm{Fe}_{3} \mathrm{O}_{4}$ nanoparticles stabilized by chitosan and o-carboxymethylchitosan. Int. J. Pharm., v. 350, p. 361-368, 2008. 